University of Wisconsin Milwaukee

UWM Digital Commons

Theses and Dissertations

December 2017

\title{
Soil-grapevine Interactions: Insight from Verdicchio in the Marche Wine Region, Italy
}

Megan Luna Barlow

University of Wisconsin-Milwaukee

Follow this and additional works at: https://dc.uwm.edu/etd

Part of the Geochemistry Commons, Plant Sciences Commons, and the Soil Science Commons

\section{Recommended Citation}

Barlow, Megan Luna, "Soil-grapevine Interactions: Insight from Verdicchio in the Marche Wine Region, Italy" (2017). Theses and Dissertations. 1583.

https://dc.uwm.edu/etd/1583

This Thesis is brought to you for free and open access by UWM Digital Commons. It has been accepted for inclusion in Theses and Dissertations by an authorized administrator of UWM Digital Commons. For more information, please contact open-access@uwm.edu. 


\title{
SOIL-GRAPEVINE INTERACTIONS: INSIGHT FROM VERDICCHIO IN THE MARCHE WINE REGION, ITALY
}

\author{
by \\ Megan Luna Barlow \\ A Thesis Submitted in \\ Partial Fulfillment of the \\ Requirements for the Degree of \\ Master of Sciences \\ in Geosciences
}

at

The University of Wisconsin-Milwaukee

December 2017 


\section{ABSTRACT \\ SOIL-GRAPEVINE INTERACTIONS: INSIGHT FROM VERDICCHIO IN THE MARCHE WINE REGION, ITALY}

by

\section{Megan Luna Barlow}

The University of Wisconsin-Milwaukee, 2017

Under the Supervision of Professor Barry Ian Cameron

Verdicchio is a white grape varietal notably grown in the Marche wine region of eastcentral Italy within two Denominazione Origine Controllata (DOCs); Castelli di Jesi and Matelica, located less than $50 \mathrm{~km}$ apart. Jesi lies in the Apennine foothills near the coast of the Adriatic Sea and produces a smooth wine noted with apple-pear undertones and crisp, clean acidity. Conversely, Matelica is located in a synclinal valley of a fold-and-thrust belt and produces stronger wine with penetrating floral aromas and bold acidity. While macro-climatic variations do exist between DOCs, this research focuses on geological variations, specifically variations in soil composition, and understanding how geology could affect the grapevine nutrient supply contributing to the distinct wine flavor characteristics noted between DOCs.

In order to quantify variations in both soil and plants between DOCs, several soil and plant analyses were conducted. This study focused upon soil samples collected within eight vineyards, with a total of ten soil profiles, and ten grapevine stem samples collected next to each soil profile. Soil samples were analyzed for soil texture, $\mathrm{pH}$, organic matter, mineralogy, elemental and oxide concentrations, plant available nutrients, base saturation, cation exchange capacity, macronutrient element concentrations $(\mathrm{N}, \mathrm{C}$, and $\mathrm{P})$, and $\mathrm{N}$ isotopes $\left(\delta^{15} \mathrm{~N}\right)$. Grapevine stem samples were also analyzed for macronutrient elements $(\mathrm{N}, \mathrm{C}$, and $\mathrm{P})$ and $\mathrm{N}$ isotope composition $\left(\delta^{15} \mathrm{~N}\right)$. The isotopic $\mathrm{N}$ ratios of grapevine stems and soil were used in a model to 
assess $\mathrm{N}$ turnover within the individual grapevine samples, assuming literature values for amino acid turnover.

This study provides insight as to how soil variations could influence wine character through quantifying soil-grapevine interactions. I speculated that differences in $\mathrm{N}$ isotopes for both soil and plants between DOCs would reflect different biological processes, with primary focus on the biological processes occurring within grapevine stems. $\mathrm{N}$ isotope fractionation in grapevine stems were interpreted to reflect rates of amino acid synthesis as grapevine stems (woody tissue) are used as sites for amino acid storage. The $\mathrm{N}$ turnover model (related to amino acids) calculated that Jesi had double the $\mathrm{N}$ turnover in comparison to Matelica throughout the growing season. I interpreted this higher rate of amino acid synthesis within Jesi grapevine stems to be a direct result of mineralogical differences measured between the two DOCs. The majority of Jesi soil profiles were determined to have dolomite $\left(\mathrm{CaMg}\left(\mathrm{CO}_{3}\right)_{2}\right)$, while Matelica soil profiles lacked dolomite. As a magnesium carbonate, dolomite most likely contributed to Jesi's higher soil Mg concentrations in comparison to Matelica. $\mathrm{Mg}$ is an important soil macronutrient acting as the coordinating ion of chlorophyll as well as activating many enzymes needed for plant vitality. Jesi grapevine stems were also analyzed as having increased $\mathrm{P}$ concentrations, possibly further promoting Jesi's plant energy metabolism. Jesi's higher soil Mg concentration and higher grapevine stem $\mathrm{P}$ concentrations could impact plant metabolic processes such as chlorophyll synthesis as well as phenolic compound character, specifically tannins, which are known to influence wine character. Previous studies have correlated wine tannin characteristics to certain soil compositions. This study improves our understanding of how geological variations impact plant biological processes, and in turn, accounts for the flavor dichotomy noted between Verdicchio wine from both Jesi and Matelica. 
(C) Copyright by Megan Luna Barlow, 2017

All Rights Reserved 
To

My parents, my greatest supporters

and my sister, Giulia, who taught me the necessary survival skills required for the completion of this document 


\section{TABLE OF CONTENTS}

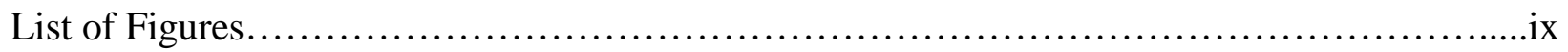

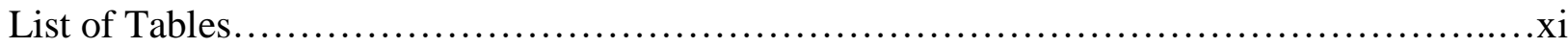

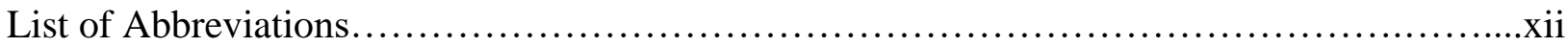

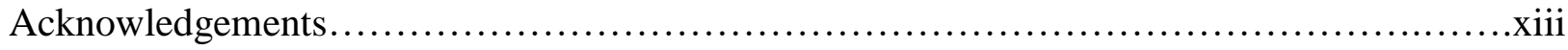

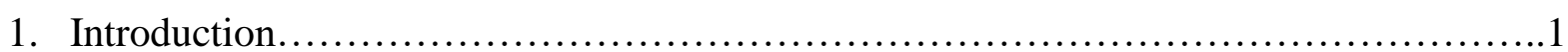

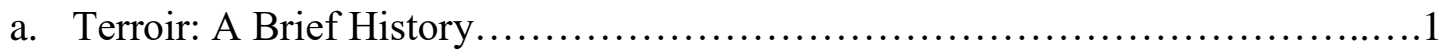

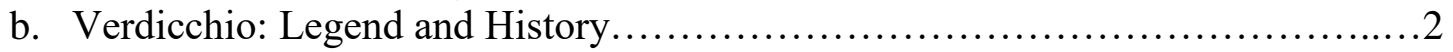

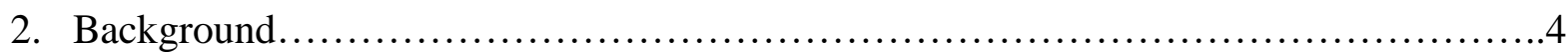

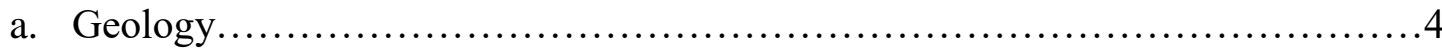

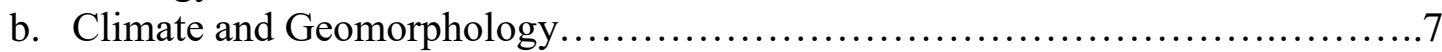

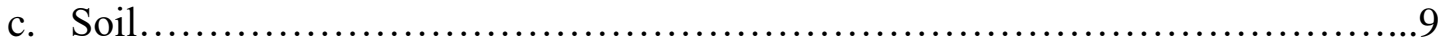

d. Soil Nutrients vs. Plant Available Nutrients......................................... 10

e. Grapevine: Function, Anatomy, and Phenology ............................. 12

f. Soil Nutrients: Their Role in Grapevine Vitality ............................... 14

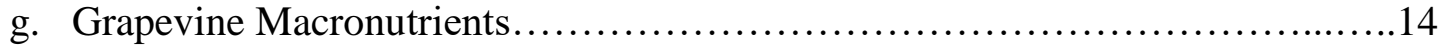

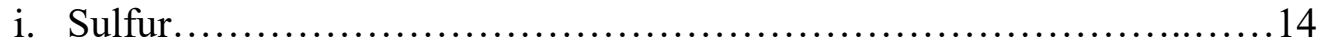

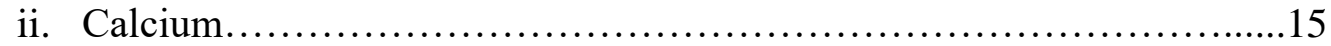

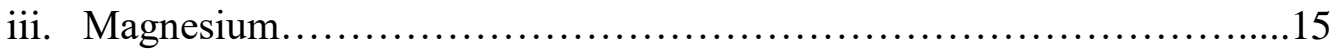

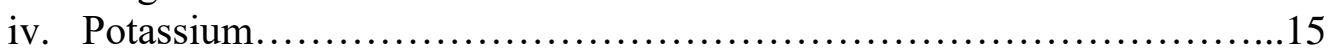

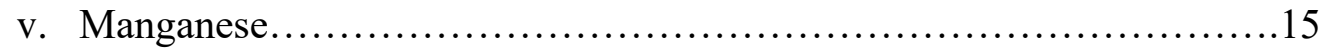

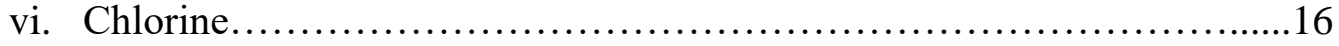

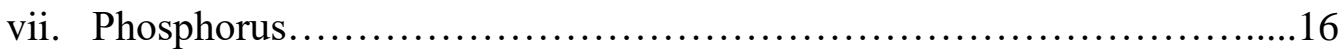

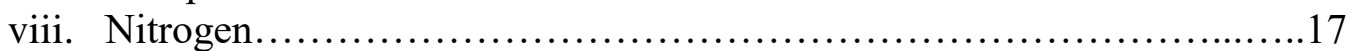

1. Plant N Uptake and Assimilation...............................18

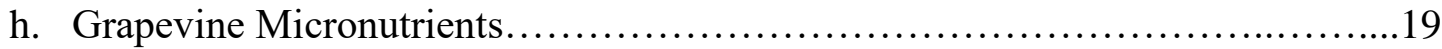

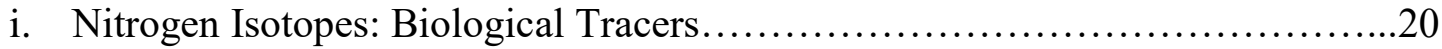

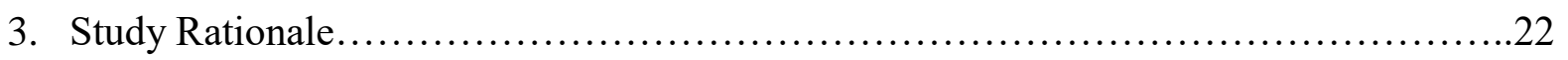

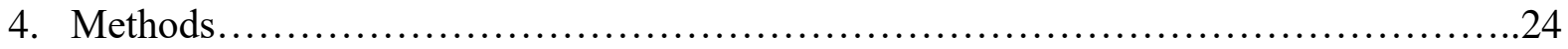

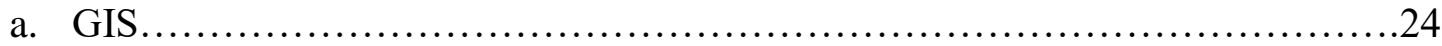

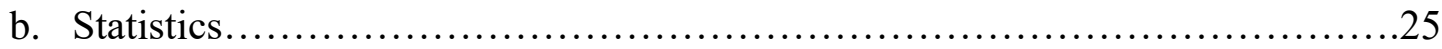

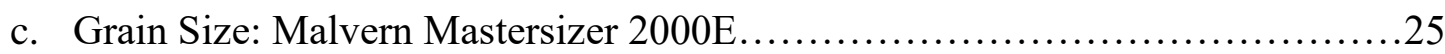

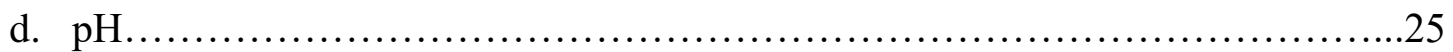

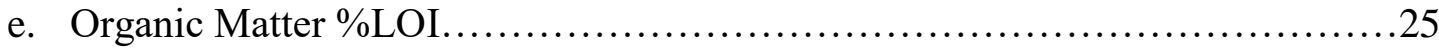

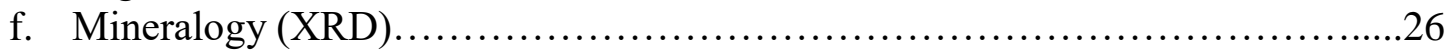




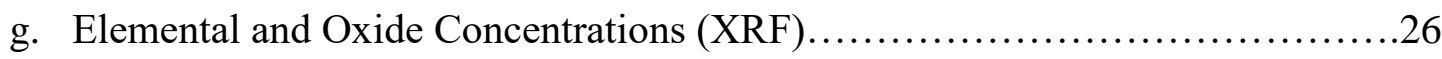

h. Cation Exchange Capacity and Base Saturation..............................27

i. Elemental Analyzer: Nitrogen and Carbon....................................27

j. Total Phosphorus Content..............................................28

k. Analysis for Plant Available Nutrients: Nitrate and Phosphate..................28

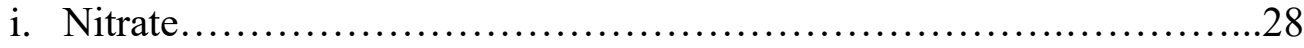

ii. Phosphorus: Olsen Phosphorus Method...........................29

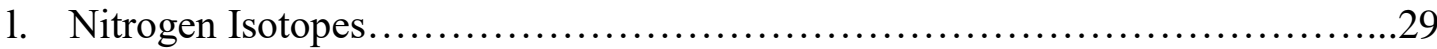

m. Nitrogen Turnover..................................................... 30

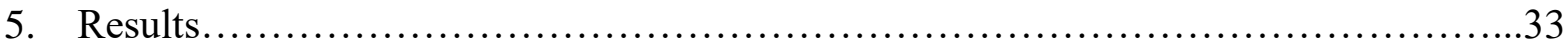

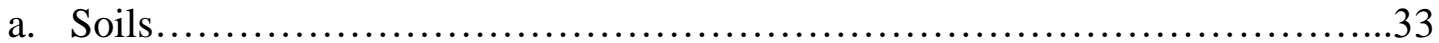

i. Texture, $\mathrm{pH}$, Organic Matter Content...............................33

ii. Mineralogy, Elemental, and Oxide Concentrations......................34

iii. Base Saturation and CEC ............................................37

iv. Total $\mathrm{N}$ Content wt $\%$ and Plant Available $\mathrm{NO}_{3}{ }^{-}$wt $\%$.............................38

v. Total C Content wt\% .........................................................................40

vi. Total P Content wt $\%$ and Plant Available $\mathrm{P}$ wt\% ..................................44

vii. Soil: Elements N, C, and P......................................43

b. Grapevine Stems................................................ 45

i. Total N, C, and P Content wt\% ..........................................................45

ii. Grapevine Stems: Elements N, C, and P...........................45

c. Soil-Grapevine Stem Comparisons..................................... 47

i. Soil-Grapevine Stem N Interactions..............................47

ii. Soil-Grapevine Stem P Interactions...............................49

iii. Soil-Grapevine Stem N Isotopes...................................51

iv. Soil-Grapevine Stem Nitrogen Turnover............................52

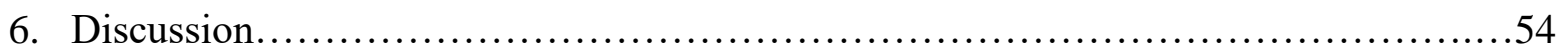

a. Soil pH, Texture, Organic Matter, CEC, and Base Saturation..................54

b. Mineralogy, Elemental, and Oxide Concentrations .........................56

c. Soil Concentrations: N, C, and P..........................................57

d. Grapevine Stem Concentrations: N, C, and P............................... 58

e. N Isotopes and N Turnover: Interpreting Biologic Rates......................59

f. Verdicchio: Understanding the Wine Flavor Variation.......................62

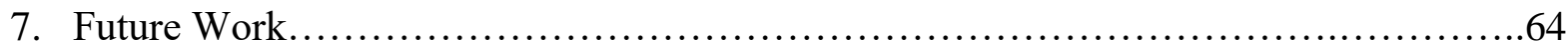

8. Conclusions...........................................................65

References.....................................................................66

Appendix A: Sample Profile, Sample ID, and Location.................................. 71

Appendix B: Jesi Soil Texture Triangle........................................................... 73 
Appendix C: Matelica Soil Texture Triangle.

Appendix D: Jesi and Matelica Soil pH and Organic Matter....................................75

Appendix E: Complete Soil Semi-Quantitative Mineralogy ...................................76

Appendix F: Total Jesi XRF Oxide Concentrations wt\% ............................................................

Appendix G: Total Jesi XRF Oxide and Elemental Concentrations ppm......................78

Appendix H: Total Matelica XRF Oxide Concentrations wt\% .....................................................79

Appendix I: Total Matelica XRF Oxide and Elemental Concentrations ppm....................80

Appendix J: Mean Jesi and Matelica XRF Elemental and Oxide Concentrations................81

Appendix K: Jesi and Matelica Base Saturation and CEC................................. 82

Appendix L: Jesi Soil Elemental Concentrations N, C, and P wt\% ............................................83

Appendix M: Matelica Soil Elemental Concentrations N, C, and P wt\% ......................................84

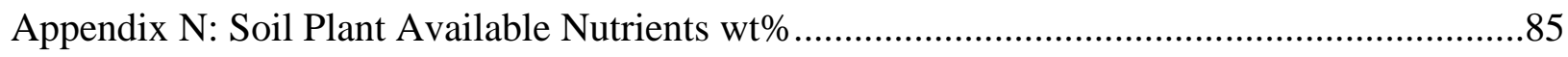

Appendix O: Grapevine Stem Elemental Concentrations N, C, and P wt \% ..................................86 


\section{LIST OF FIGURES}

Figure 1. Study Area: DOCs of Jesi and Matelica............................................

Figure 2. Jesi and Matelica DEM image displaying geomorphology .........................6

Figure 3. Soil pH vs. Soil Organic Content \%LOI.........................................33

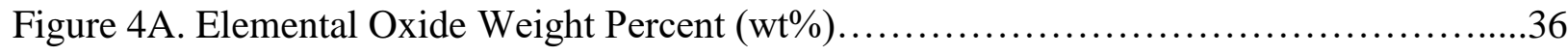

Figure 4B. Elemental and Oxides Parts Per Million (ppm) .................................36

Figure 5. Individual Vineyard vs. $\% \mathrm{MgO}$ concentration at $10 \mathrm{~cm}$ in soil depth...................37

Figure 6. Plant Available $\mathrm{NO}_{3}{ }^{-}$(wt\%)vs. Soil N Content (wt\%) ............................... 39

Figure 7A. Soil N Content (wt\%) vs. Organic Matter (\%LOI) ..............................41

Figure 7B. Soil C Content (wt\%) vs. Organic Matter (\%LOI) ..............................41

Figure 7C. Soil P Content (wt\%) vs. Organic Matter (\%LOI) ..............................41

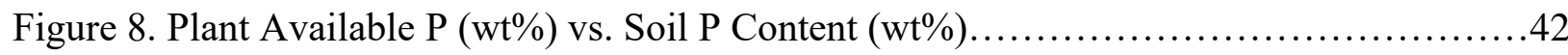

Figure 9A. Soil N Content (wt $\%$ ) vs. Soil C Content (wt\%) .................................44

Figure 9B. Soil P Content (wt\%) vs. Soil C Content (wt\%) ...............................44

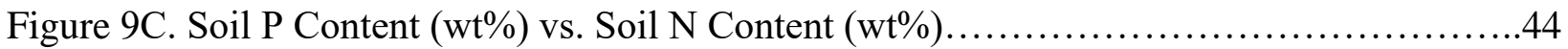

Figure 10A. Grapevine Stem N Content (wt\%) vs. Grapevine Stem C Content (wt \%)...........46

Figure 10B. Grapevine Stem P Content (wt\%) vs. Grapevine Stem C Content (wt\%)...........46

Figure 10C. Grapevine Stem P Content (wt \%) vs. Grapevine Stem N Content (wt\%)...........46

Figure 11A. Grapevine Stem N Content (wt\%) vs. Soil N Content (wt $\%) \ldots \ldots \ldots \ldots \ldots \ldots \ldots \ldots . . . . . . . . .48$

Figure 11B. Grapevine Stem N Content (wt $\%)$ vs. Plant Available $\mathrm{NO}_{3}{ }^{-}(\mathrm{wt} \%) \ldots \ldots \ldots \ldots \ldots \ldots . .48$

Figure 12A. Grapevine Stem P Content (wt\%) vs. Soil P Content (wt\%).......................50

Figure 12B. Grapevine Stem P Content (wt\%) vs. Plant Available P (wt $\%) \ldots \ldots \ldots \ldots \ldots \ldots \ldots . . \ldots 50$

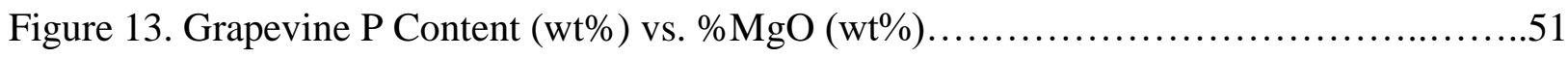




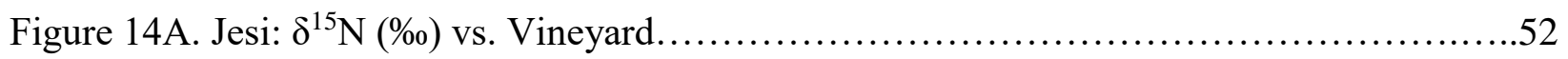

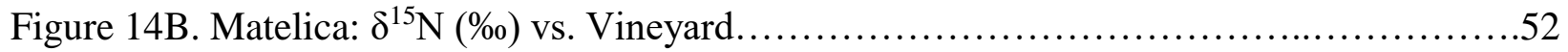




\section{LIST OF TABLES}

Table 1. Vineyard Elevation, Slope, and Aspect......................................... 9

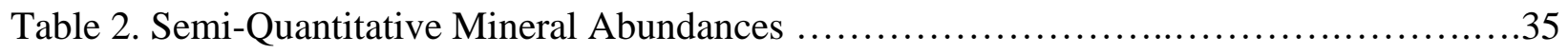

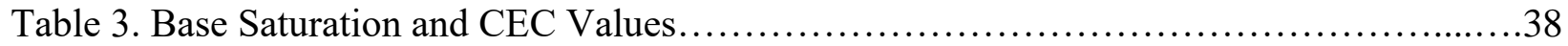

Table 4. Soil Macronutrient, Plant Available Nutrients, and Soil C:N, C:P, and N:P...........39

Table 5. Grapevine Stem Macronutrient and Stem C:N, C:P, and N:P $\ldots \ldots \ldots \ldots \ldots \ldots \ldots \ldots \ldots$

Table 6. Grapevine N Turnover..................................................53 


\section{LIST OF ABBREVIATIONS}

ASSAM Agenzia Servizi Settore Agroalimentare delle Marche (Agricultural Agency of the Marche)

CEC Cation Exchange Capacity

Cfa Humid subtropical climate (mesothermal)-Hot summer

Cfb Temperate oceanic climate (mesothermal)-Warm summer

DEM Digital Elevation Model

DOC Denominazione di Orignie Controllata (designated viticultural areas)

DON Dissolved Organic Nitrogen

GIS Geographical Information System

LOI Loss On Ignition

SD Standard Deviation

U-M Umbro-Marchigiano Apennines

USDA United States Department of Agriculture

XRD X-Ray Diffraction

XRF X-Ray Fluorescence 


\section{ACKNOWLEDGMENTS}

This research was made possible through grants provided by the Wisconsin Geological Society, the Thomas Hooyer Award, and Geoscience Department grants at the University of Wisconsin-Milwaukee.

A special thanks to E. Paris at the University of Camerino, who spent countless hours with me on Elba Island every summer and inspired me to pursue geology as a career. She also largely supported this project from the beginning and helped attain necessary assistance in the field as well as establish amicable connections in the area.

I could not have conducted fieldwork without the assistance of M. Gentilucci, who at the time, was in the process of finishing his doctoral dissertation. He excavated a vast majority of my soil profiles cutting my field days in half! I was also graciously assisted by G. Ciabocco, who works for the Agenzia Servizi Settore Agroalimentare delle Marche (ASSAM) and volunteered professional soil insight through his assistance in the field. Moreover, I would also like to thank all staff personnel at ASSAM especially M. Tiberi and C. Bernacconi.

This project would not have been possible without the cooperation of vineyard owners and staff. Selected vineyards in Jesi include Frati Bianchi Sparapani, Vignamato, Mancini, and La Staffa, and selected vineyards in Matelica include Belisario, Gagliardi, Maraviglia, and Colle Stefano. Thank you for granting me access to your vineyards making this project possible.

A special thanks to my advisers B. Cameron and E. Gulbranson, who have guided me throughout this whole process. It all started with a tiny seed that was carefully cultivated to become this very document. This research has come a long way due to their tireless dedication to the subject matter as well as their continuous support. 
And to my committee member, E. Young, thank you. You have taught me to think critically and organize my writing in a clear linear fashion. My biological interpretations would have been lesser without you. Thanks to W. Kean for acting as a stand-in committee member for the actual defense. Your support was immensely appreciated. In addition, a gracious thanks to $\mathrm{L}$. McHenry, J. Rawlings, and J. Berges who granted me use of their lab/equipment for tests needed to complete my research. Overall, I am forever grateful for everyone's time and effort in guiding me through this two-and-half year adventure. And to my colleagues and friends, you've made coming to school/work each and everyday worth it.

Lastly, I would like to thank my Nonno, Nonna, and Uncle Robby whom graciously granted me the use of their car as well as financially supported me during my stay in Italy. I am forever grateful for their help and kindness, but I am especially thankful to my Uncle Robby, who has been an immense supporter of my work and even joined me on an additional viticultural expedition after fieldwork was completed. I also would like to dedicate this thesis to my Nonno, who sadly past away in the Spring of 2017. 


\section{INTRODUCTION}

\section{Terroir: A Brief History}

The French term, terroir, dates back to the $14^{\text {th }}$ century in a time when Benedictine and Cistercian monks cultivated the land along the Côte d'Or in Burgundy, France. They used the term terroir when referring to certain top-quality wine-producing properties (Wilson, 2001). While the initial designation of "good" vs. "bad" terroir was primarily conducted through trial and error, science eventually revealed consistent elements that yielded favorable qualities for the production of fine wine. Terroir now commonly encompasses all physical parameters affiliated with the habitat of a grapevine intended for the production of wine and is sometimes referred to

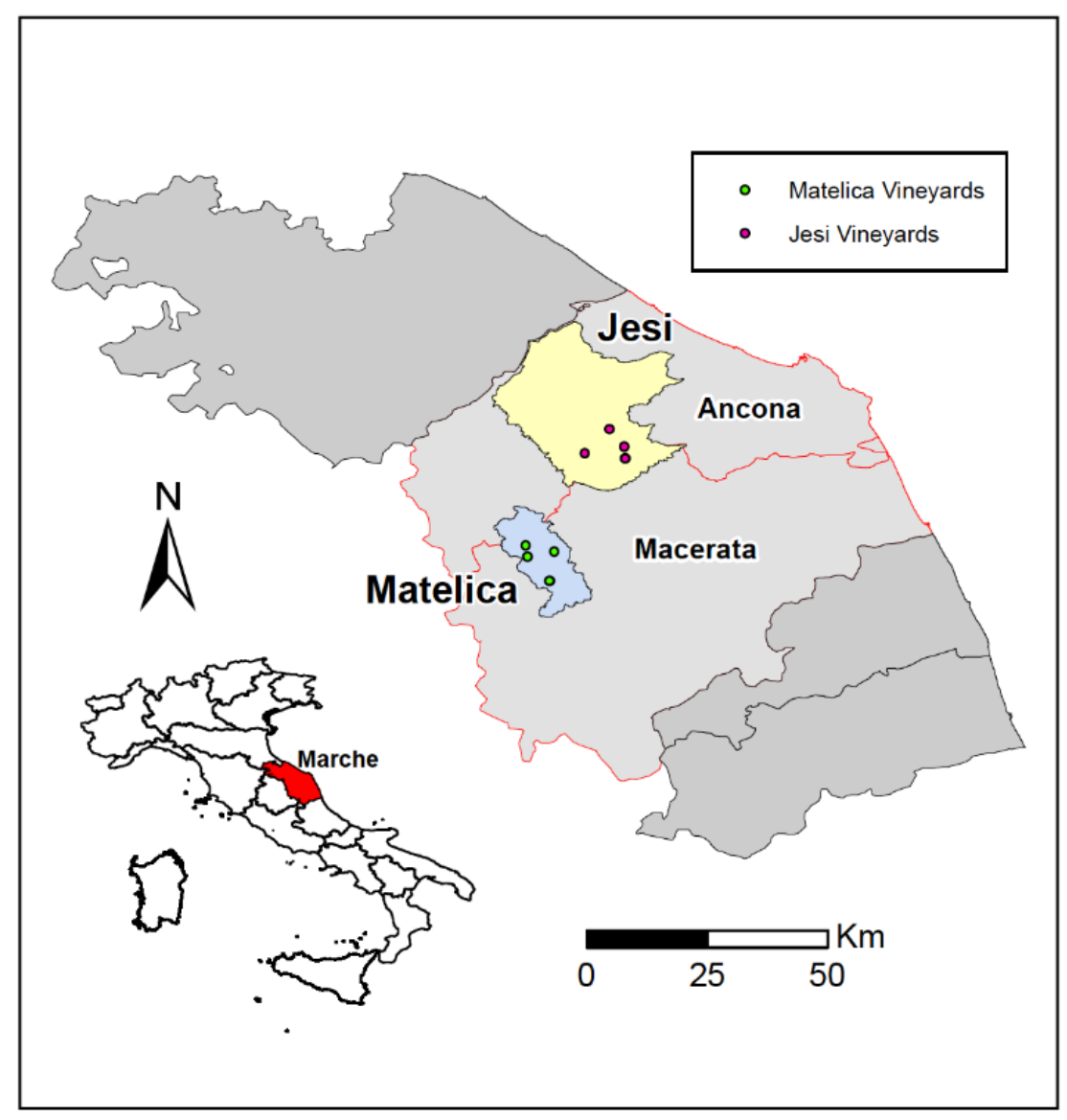

as the 'terroir effect', which include the disciplines of geology, geomorphology, soil, climate, and grapevine biology (Sequin, 1986: van Leeuwen, 2010). Terroir can be described based upon grape and/or wine characteristics through the scientific investigation of all terroir parameters, or a single terroir parameter.

Figure 1: Study area in the Marche wine region of the two DOCs: Jesi (yellow) and Matelica (blue). Note the close proximity of the two DOCs. Sampled vineyards also shown. 


\section{Verdicchio: Legend and History}

The first Italian DOC was created in 1966, following the French example of labeling wine regions by appellations through laws created in the 1930's (Bastianich and Lynch, 2002). DOCs were established to produce wine of regulated quality and commercial standards that could be controlled and advertised for global distribution. Moreover, DOCs guarantee the origin of grapes from certain areas (Bastianich and Lynch, 2002). In the old world, DOCs are typically created in viticultural regions where certain grape varietals thrive. This is commonly reflected and emphasized on wine labels that highlight regions versus grape varietals. This style of labeling requires prior knowledge of the wine region to understand the nature/variety of wine upon purchase.

Out of the twenty regions in Italy, the Marche is latitudinally centralized in the peninsula and located along the east coast by the Adriatic Sea (Fig. 1). While the Marche is bound by the Adriatic Sea to the east, the west side of the region is bordered by the Umbro-Marchigiano Apennines (U-M). It is home to five provinces and hosts twelve DOCs. This study focuses on two of the twelve DOCs. The DOC, Verdicchio di Matelica, was established in 1967, while the DOC, Verdicchio dei Castelli di Jesi, was established soon after in 1968 (Bastianich and Lynch, 2002). Though these DOCs were established 50 years ago, the Marche has been cultivating Verdicchio for much longer. Verdicchio is an exceedingly well-established white grape varietal in Italy often described as one of Italy's "most interesting" native white grapes and as a "white with the structure of a red" (Bastianich and Lynch, 2002). Verdicchio wine is often noted to be "green" in flavor with high acidity and "distinctly piney, resiny flavor, along with suggestions of sour apple, bosc pear, and green herbs" (Bastianich and Lynch, 2002). Though many wine enthusiasts agree with the above general wine profile of green fruit and herbs, Verdicchio di 
Matelica is characterized as a slightly more powerful version of Verdicchio than Verdicchio di Jesi (Bastianich and Lynch, 2002). Verdicchio di Jesi has a smooth body and crisp clean acidity with apple, pear, green herb undertones, and bitter-almond finish (Bastianich and Lynch, 2002; Conte et al., 2006). Verdicchio di Matelica tends to be more muscular and firmly structured with penetrating floral aromas and bold acidity expressing more depth and minerality than Jesi (Bastianich and Lynch, 2002; Conte et al., 2006). Because of prestigious DOC regulations and Verdicchio's distinct wine character dichotomy noted between the two DOCs, Verdicchio wine labels clearly print whether it was produced in Jesi or in Matelica.

Jesi has an area of $\sim 573 \mathrm{~km}^{2}$ compared to Matelica at $\sim 157 \mathrm{~km}^{2}$, which is about 3.6x smaller than Jesi. In turn, Jesi produces a larger quantity of Verdicchio based on its greater area extent (Bastianich and Lynch, 2002). It is noted that Verdicchio wine grown in Matelica is more consistent and homogeneous due to its smaller yield compared to Verdicchio from Jesi (Conte et al., 2006). Because of this unequal Verdicchio distribution, Verdicchio from Jesi is more popular amongst general white wine drinkers resulting in slightly higher priced Jesi Verdicchio compared to Matelica (Bastianich and Lynch, 2002).

Verdicchio grapevines have been identified through genetic testing as a relative of Trebbiano di Soave and Trebbiano di Lombardy, but more robust in flavor and aroma and is thought to have been introduced in the Marche region in the early $17^{\text {th }}$ Century (Franzan, 2000; Bastianich and Lynch, 2002; Conte et al., 2006). The overall history of the Marche region is rich with mystery as to where Verdicchio was exactly was first cultivated, but this no doubt adds to the allure of the widely established Italian white grape varietal that is so distinctly different within the DOC's of Jesi and Matelica. 


\section{BACKGROUND}

While located less than $50 \mathrm{~km}$ apart, the DOCs of Jesi and Matelica exhibit pronounced variations in geology, climate, geomorphology, and soil, which will be introduced below. After the geologic overview, three sub-sections will be presented: 1) the basics of soil nutrients vs. plant available nutrients, grapevine: function anatomy, and phenology; 2) soil nutrients: their role in grapevine vitality, grapevine macronutrients and grapevine micronutrients; and 3) nitrogen isotopes: biological tracers. These three sub-sections will review the key components of soil-grapevine interactions with which to assist in latter understandings as to how these interactions could influence wine characteristics.

\section{Geology}

The geological and structural history of the Apennines spans over $\sim 20$ m.y. and spatially covers a length of 1,200 km throughout the middle of the Italian Peninsula as a direct result of south-eastward retrograde migration of the Adriatic trench and ongoing subduction (Cavinato and De Celles, 1999). The northeastern Apennines are dominated by fold-thrusting, while the southwestern part is dominated by extension (Cavinato and De Celles, 1999). The subduction occurring along the east is thought to be segmented and that the weight of the subducting slab has resulted in southward migration of the zone of subduction (Royden et al., 1987). The segmentation and configuration of the subducting plate is believed to be a large controlling factor of the surface deformation observed in the Apennine system due to foredeep-basin geometry and thrust-belt evolution (Royden et al., 1987).

The U-M Apennines are mainly attributed to a foreland fold-and-thrust belt formed in the latest phase of the Alpine-Himalayan orogenesis (Conte et al., 2006). Overall, the U-M Apennines were tectonically created through two main phases: 1) compressional arc shaped folds and thrusts from the Alpine-Himalayan orogenesis in the late Miocene-Early Pliocene, 2) 
extension creating multiple faults including NW-SE trending normal faults and major thrust and oblique faults in the late Pliocene-Pleistocene with some major thrust and oblique faults occurring as early as the Upper Miocene (Barchi, 1991; Conte et al., 2006). The U-M Apennines are characterized by parallel NE verging thrust anticlines forming two main ridges: 1) Marche anticlinal ridge located to the east, 2) U-M anticlinal ridge located to the west (Barchi, 1991; Conte et al., 2006). Both anticlinal ridges range between 1,000 and 1,700 $\mathrm{m}$ above sea level with a synclinal valley nestled in-between (Conte et al., 2006). The two anticlines merge to the south creating the Sibillini Mountains with peaks reaching nearly 2,500 $\mathrm{m}$ in elevation (Conte et al., 2006). The DOC of Jesi and Matelica are separated by the Marche anticlinal ridge along with various faults. The DOC of Matelica is located within the synclinal valley between the two anticlinal ridges, while the DOC of Jesi is located to the east of the Marche anticlinal ridge of the Marche foothills stretching out towards the coast (Fig. 2).

The geotectonic evolution of the U-M Apennines is divided stratigraphically into two main successions; the carbonate succession ranging from Early Jurassic to mid-Miocene and the siliciclastic succession ranging from Late Miocene to Pleistocene (Conte et al., 2006). The carbonate succession is attributed to deep-water deposition of pelagic limestone and marl formations during an extended time of extensional tectonics, while the siliclastic succession represents syn- and post-orogenic clastic deposits, which includes a wide variety of deposits such as the flysch sequences of the Marnoso-Arenacean and Laga Formations, the Gessoso-Solfifera Formations consisting of black shales and evaporites of the Messinian, the turbiditic silt and clay of the Colombacci Formation, and lastly, the ultimate emergence of the Apennine orogen represented by molasse, fluvial, lacustrine, and beach deposits (Conte et al., 2006). These siliclastic formations are dominantly found in the inter-mountain synclinal valley that hosts the 
DOC of Matelica, whereas the DOC of Jesi occupies the gentle slope toward the Adriatic Sea (Conte et al., 2006). While Jesi and Matelica both primarily rest upon siliciclastic dominated bedrock, lithologic variations do exist. Conte et al. (2006) observed that Jesi Verdicchio grows upon three main types of rock formations: 1) silty clays occasionally interbedded with poorly cemented sandstones in the upper Pliocene, mostly in the lower, most open parts of the valleys,

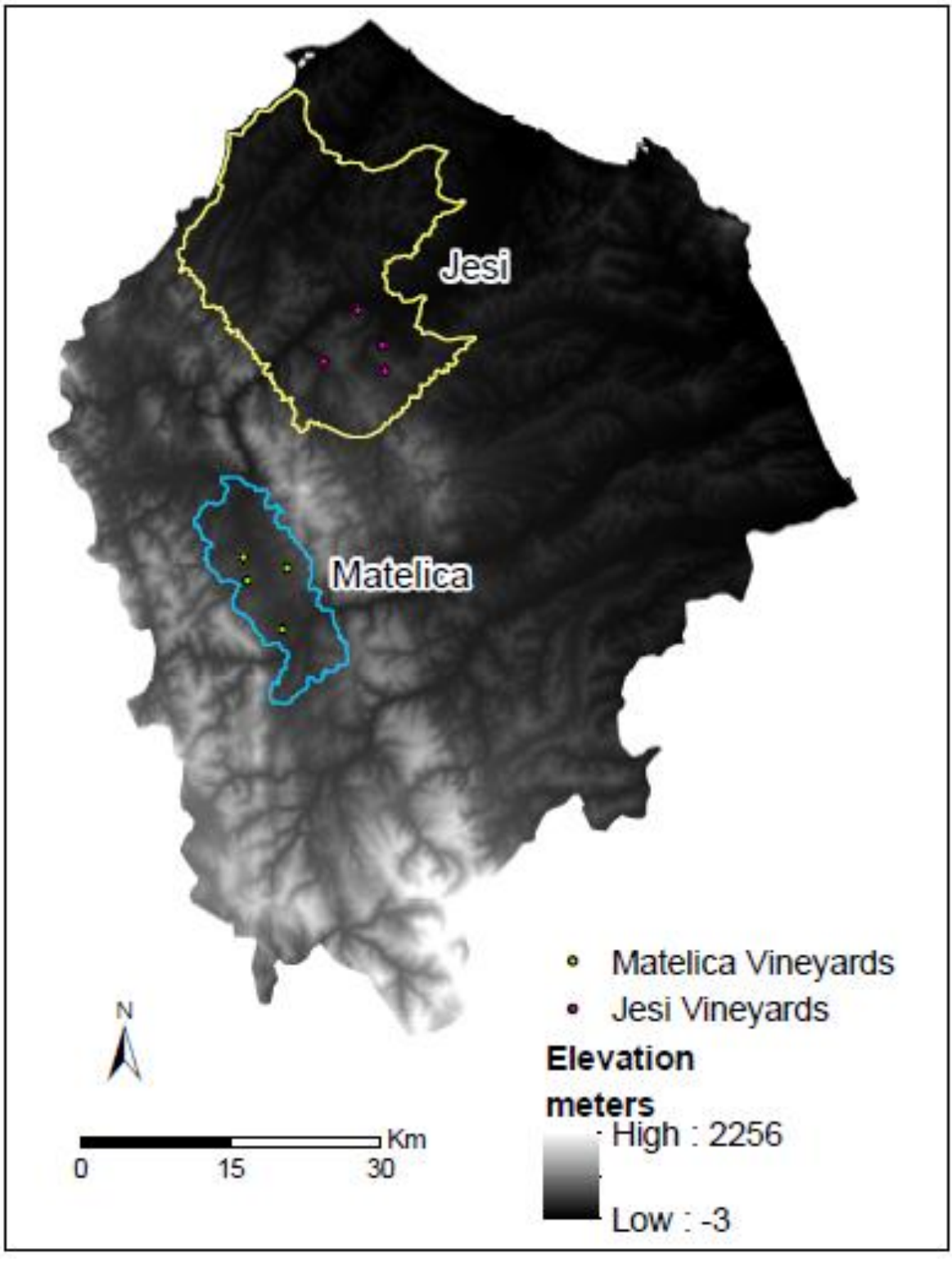

Figure 2: Jesi is located at the base of the Apennine foothills stretching towards the Adriatic coast, while Matelica is situated within a synclinal valley located more inland.
2) poorly cemented

sandstones in thick

turbidite beds

intercalated with marls throughout in the mid and lower Pliocene primarily in the upper part of the valleys, and 3) upper Miocene primarily consists of more or less clay-rich marls with marly limestones topped by Messinian evaporites. Conte et al. (2006) also noted that Matelica Verdicchio grows upon soil derived from 
limestones and marls ranging from lower to mid Miocene, capped by molasse and quartzmicaceous turbiditic sandstones ranging from mid-upper Miocene, and were also found to be interbedded with pelitic marls. Thus, according to geologic research of Conte et al. (2006), Matelica soil tends to be more carbonate-rich than the soils of Jesi. It should, however, be noted the selected vineyards in Jesi for this study are located in the southern portion of the DOC, where pelagic limestones are abundant. Geology can vary significantly over small spatial scales and should always be tested regardless of literature.

\section{Climate and Geomorphology}

Knowing the tectonic evolution of the Marche aids in understanding the climatic and geomorphic variations noted between DOCs.

Timing of fruit ripening is in large part related to local climate conditions (van Leeuwen, 2010). Whereas microclimate variations exist between individual vineyards, this section will focus on the mesoclimate variation between DOCs. The geomorphic characteristics of Jesi and Matelica in part contributes to mesoclimate variability. Due to Jesi position, located at the base of the Apennine foothills and stretching out towards the Adriatic coast, it is situated at relatively low elevations compared to the DOC of Matelica, which is located within a synclinal valley of a fold-and-thrust belt at higher elevations (Fig. 2). Jesi enjoys a more marine climate based on a close proximity to the coast affected by warm air currents off the Adriatic Sea resulting in minor temperature excursions (Conte et al., 2006). The DOC of Jesi is relatively large and falls into two Köppen-Geiger climate classifications (Gimsing, 2014). To the north, a Cfa climate predominates with warmer temperatures, fully humid, and hot summer and the southern side of the DOC is dominated by a Cfb climate, identical to Cfa except for warm instead of hot summers (Gimsing, 2014). Selected vineyards for this study lie within the southern portion of the Jesi 
DOC (Cfb climate). Matelica is located further inland and has a continental climate, situated in a NW-SE synclinal valley with north-south running air currents and experiences solar shading by the anticlinal mountain ranges (Conte et al., 2006). Moreover, the DOC of Matelica falls into a $\mathrm{Cfb}$ climate experiencing the same climate regime as the southern portion of the DOC of Jesi (Gimsing, 2014). According to data collected by the Agenzia Servizi Settore Agroalimentare delle Marche (ASSAM- Agricultural Agency of the Marche) within the years 1997-2003, Jesi experiences mean annual temperature fluctuations of $13-15^{\circ} \mathrm{C}$ compared to Matelica, which annually fluctuates between 13 and $14^{\circ} \mathrm{C}$. During the critical summer months where fruit maturation takes place, Jesi temperatures fluctuates between $10^{\circ} \mathrm{C}$ to $14^{\circ} \mathrm{C}$ compared to Matelica, which fluctuates between $12^{\circ} \mathrm{C}-17^{\circ} \mathrm{C}$, thus slightly warmer, but has greater temperature fluctuations in comparison to Jesi (Conte et al., 2006). As for annual precipitation, they experience similar values at $\sim 900-1,100 \mathrm{~mm} / \mathrm{year}$ (Conte et al., 2006). As a result of mesoclimate and geomorphic variations between the DOCs, Jesi vineyards typically harvests their Verdicchio grapes approximately 10-15 days earlier than their counterparts in Matelica (Bastianich and Lynch, 2002).

Overall, soil profiles from selected vineyards in Jesi were sampled on steeper slopes (avg. $10.6^{\circ}$ ) compared to soil profiles in Matelica sampled on more gentle slopes (avg. $6.2^{\circ}$ ). Variations in elevation, slope, and aspect is summarized in table 1, which was compiled through Geographic Information System (GIS) analysis. 
Table 1: Five soil profiles were excavated in each

DOC. Jesi vineyards are situated at a lower

elevations from vineyards in Matelica ranging from

165 to $345 \mathrm{~m}$ with a varying degree of slope and

northerly aspect. Matelica vineyards are situated at

higher elevations compared to Jesi vineyards ranging from 391 to $460 \mathrm{~m}$ with noticeably more gentle slopes and a south easterly apect.

\begin{tabular}{cccc}
\hline Soil Profiles & Elevation $(\mathbf{m})$ & Slope $\left(^{(}\right)$ & Aspect $\left(^{\circ}\right)$ \\
\hline Jesi & & & \\
\hline 1 & 218 & 8.65 & 261 \\
\hline 2 & 165 & 15.35 & 330 \\
\hline 3 & 209 & 2.86 & 0 \\
\hline 4 & 330 & 19.69 & 25 \\
\hline 5 & 345 & 6.46 & 265 \\
\hline Matelica & & & \\
\hline 1 & 460 & 8.65 & 171 \\
\hline 2 & 391 & 6.38 & 117 \\
\hline 3 & 409 & 5.71 & 180 \\
\hline 4 & 415 & 5.05 & 82 \\
\hline 5 & 422 & 5.44 & 67 \\
\hline
\end{tabular}

\section{Soil}

Soil composition, structure, and texture varies tremendously across spatial scales and vertically within the soil layers. Soil is unique from area to area and varies within and between vineyards and across DOCs. Soil is derived from the weathering of parent materials; and is therefore sensitive to the composition of surficial sedimentary deposits or bedrock, when it is exposed at the land surface. Soil is also a product of its climate, soil organisms, topographic relief (geomorphology), and time (Jenny, 1980). These physical parameters have great impact on soil development, profiles, and patterns of soil quality and character (Sposito, 2008).

As a heterogeneous medium, soil is a mixture of solids, liquids, gases, all interconnected with pore spaces (Sposito, 2008). The solid material of soil is a mixture of mineral and organic matter, which depends on lithologic, biologic, and climatic variations (Sposito, 2008). Soils are 
typically rich in silica, $\mathrm{SiO}_{2}$, a common component of Earth's continental crust. Elements $\mathrm{Si}$ and O can chemically combine with other cations to produce approximately fifteen common silicate minerals (Sposito, 2008). These silicates are subdivided into primary minerals, derived from parent material, and secondary minerals, which are precipitated out or an altered product of a primary mineral (Sposito, 2008). Soil primary carbonate minerals including calcite $\left(\mathrm{CaCO}_{3}\right)$ and dolomite $\left(\mathrm{CaMg}\left(\mathrm{CO}_{3}\right)_{2}\right)$ are not silicates, and are created through the chemical precipitation of carbonate compounds in marine settings and later uplifted onto the continent and later evolved into soil (Sposito, 2008). Secondary carbonate minerals are formed through the precipitation of carbonate material in situ within the soil column (Sposito, 2008). Secondary carbonates are typically found as precipitated nodules within the soil, hardened layers, filaments, clay or silt particles, or as mineral coating on soil grains (Sposito, 2008). Understanding the mineralogy of soil, thus the chemical composition of the soil, is critical to understanding soil geochemistry and how it can impact vine development and fruit ripening (van Leeuwen, 2010). Minerals and organic matter undergo physical, chemical or microbial alteration and may be transformed into plant-available nutrient forms. Unlike minerals, organic matter is continuously added into the soil both as an influx from above and below organic structures as well as the decay of dead microbial biomass and soil macro-organisms, all generally decomposed by heterotrophic microorganisms (Sposito, 2008).

\section{Soil Nutrients vs. Plant Available Nutrients}

Chemical composition and concentration of soil depends on soil mineralogy, $\mathrm{pH}$, climate, geomorphology, soil depth, organic matter, and soil microbiology (Essington, 2004). pH affects mineral dissolution and transformations, while climate can determine rate of weathering through precipitation and solar energy influxes affecting soil temperature (Smeck et al., 1983; Essington, 
2004; Gulbranson et al., 2011). Geomorphology affects erosional patterns in soil and soil texture, which greatly determines grain surface charge impacting cation exchange capacity (CEC) and in turn, nutrient immobilization (Essington, 2004). Plant nutrients also depend on soil depth and organic matter (including both overlying vegetation and soil organic matter), which also affects CEC (Essington, 2004). Soil microbiology plays a large role in nutrient transformations and organic degradation (Essington, 2004). While present in the soil, not all soil minerals are available for plant uptake. Plants commonly take up plant available nutrients found in soil solution and sometimes can take up some forms of mineral compounds. Soil solution is a dissolved solution of compounds released into the soil water and thus readily available for plant uptake through their roots (White, 2009). Soil mineralogy dictates elemental and oxide compositions and concentrations, whereas climate and $\mathrm{pH}$ exert a prominent control on the chemistry and reactivity of aqueous soil solutions; and thus largely controlling plant nutrient availability. According to White (2009), recommended soil $\mathrm{pH}$ for grapevines is between 5.5 and 7.5 and grapevines grown outside of this soil $\mathrm{pH}$ range typically risk nutrient-deficiency or toxicity. Acidic soils have higher $\mathrm{H}^{+}$concentrations, which would displace other positively charged plant nutrients (base cations) within negatively charged soil sites (CEC), resulting in most macro- and micro-nutrient deficiencies. Deficiencies can also occur at higher pH. High pH is typically associated with soils high in carbonate material, rich in cations $\mathrm{Ca}^{2+}$ and $\mathrm{Mg}^{2+}$ (Sposito, 2008). Availability of nutrients $\mathrm{P}, \mathrm{Fe}, \mathrm{Cu}, \mathrm{Zn}$, and Mn typically decreases under high soil pH (Essington, 2004).

Plant species and genetics can influence nutrient uptake and nutrient requirements, but as this study focuses on a single grapevine varietal, Verdicchio, we can assume little plant varietal differences in nutrient uptake. Mycorrhizae, a special class of symbiotic fungi, infect plant roots 
forming a precise anatomical configurations within or on the root tissue and develope a hyphal network that extends from the infected root to the surrounding soil. Mycorrhizal associations serve to increase plant nutrient and water acquisition via the fungal network in return for carbohydrates (organic compound) produced by the plant (Ehmke, 2017). Endomycorrhizae are a widespread type of mycorrhizae that grow inside the cortical cells of a root and develop branched-like structures called arbuscules, also known as arbuscule mycorrhizal fungi (AMF) (White, 2009). AMF are common in $V$. vinifera and release nutrients directly into the plant root cells (White, 2009). While plant available nutrients were analyzed, this study does not take into account variations in fungal associations (Brundrett, 2009; White, 2009). Plant available nutrients mediated by bacteria is discussed later on in the Macronutrient section: Nitrogen.

\section{Grapevine: Function, Anatomy, and Phenology}

Grapevines are photoautotrophs capable of synthesizing their own energy and biomass through the sunlight and soil. Plant biomass is mainly comprised of carbohydrates, lipids, proteins, and nucleic acids, which are strongly dependent on the coupled cycling of $\mathrm{C}, \mathrm{N}$, and $\mathrm{P}$ (Goll, 2017). Carbohydrates and lipids are rich in $\mathrm{C}$ but low in $\mathrm{N}$ and $\mathrm{P}$, whereas nucleic acids (DNA and RNA) are rich in N and P, and proteins are rich in N, but lack $\mathrm{P}$ (Goll, 2017). C and $\mathrm{O}$ can be derived from the atmosphere through vine leaves and stems as $\mathrm{CO}_{2}$, which is used for the synthesis of sugars (White, 2009). Rubisco (Ribulose-1,5-bis-phosphate carboxylase/oxygenase) is the primary enzyme responsible for $\mathrm{CO}_{2}$ fixation during photosynthesis in $\mathrm{C}_{3}$ plants (Reich et al., 2009; Walker et al., 2014; Goll, 2017). Plant available $\mathrm{N}$ in soil is linked to the biological cycle of $\mathrm{N}$ within soil systems, specifically the $\mathrm{N}$-fixation. Plant available $\mathrm{P}$ in soil is linked to weathering and degradation of organic and inorganic materials containing $\mathrm{P}$ within soils. $\mathrm{N}$ is a critical building block in all biomass and plays a large 
role in the molecule structure of chlorophyll and is therefore linked to photosynthetic capacity (Field and Mooney, 1983; Losh et al., 2013; Goll, 2017). Both N and P are involved in plant growth, especially leaf area development, which in turn has restrictions on photosynthetic capacities (Reich et al., 2009). Additional O, along with $\mathrm{H}$, are obtained through $\mathrm{H}_{2} \mathrm{O}$, and can be derived from soil or the atmosphere (White, 2009).

The above-ground anatomy of a grapevine consists of a perennial woody structure with tendrils which grow each year and attach themselves to a trellising systems granting the vine increased access to light as well as provide structural support (Skelton, 2007). The structural support is provided by rigid woody tissue reinforced with lignin, which stores high amounts of C derived from photosynthetic C-fixation (Goll, 2017). The perennial wood rootstock and trunk expands in diameter as the vine grows older, and is responsible for many vital transport and storage functions and can be referred to as a "sink" (Skelton, 2007; Keller, 2010). Plants have special cell organelles that help store their energy and excess reserves aiding in displacing temporal and spatial imbalances between nutrient supply and demand (Goll, 2017). The trunk is also a conduit for vascular transport of water and nutrients from roots to growing shoots as well as a pathway to transport products produced by the leaves and transported to the roots to support root growth (Skelton, 2007). The vascular tissues include xylem, responsible for transport of water and mineral nutrients taken up in the roots, and phloem, which transports nutrients from the above-ground tissues to the roots, and re-translocation of stored materials around the plant (Epstein and Bloom, 2005).

Vine canes support foliage and budding shoots that flower and after pollination, turn into grapes known as the canopy (Skelton, 2007). Flower clusters (inflorescences) will turn into grapes once pollinated, with the majority of wine grape varietals producing two to three flower 
clusters per cane depending on climatic conditions of that growing season (Skelton, 2007). Fruit is produced from the branching canes of wood that grew the previous year (Skelton, 2007). The annual growing season of a vine can be measured in six phenological stages: budbreak, bloom, veraison (onset of fruit ripening), harvest, leaf fall, and dormancy (Schreiner, 2016). Wine grapes typically have peak macronutrients $\mathrm{K}, \mathrm{Ca}, \mathrm{Mg}$ and micronutrients $\mathrm{B}, \mathrm{Zn}, \mathrm{Mn}$, and $\mathrm{Cu}$ taken up between bloom and veraison, and consequently, the grapevines increase in total vine biomass (Schreiner, 2016).

\section{Soil Nutrients: Their Role in Grapevine Vitality}

Plant macronutrients are taken up from soil and converted into organic forms such as pigments, enzyme cofactors, lipids, nucleic acids, and amino acids (proteins) during plant nutrient assimilation (Taiz and Zeiger, 2010). While C, H, and O play an important role in grapevine dynamics, there are a total of sixteen essential elements needed for grapevine vitality. These are divided into the categories of macronutrients (C, H, O, S, Ca, Mg, K, Mn, Cl, P, N) and micronutrients (Fe, $\mathrm{Zn}, \mathrm{Cu}, \mathrm{B}$, and $\mathrm{Mo}$ ) (White, 2009). The majority of these essential elements are derived from the soil. Their availability is determined by a plethora of physical, biological, and chemical factors.

\section{Grapevine Macronutrients}

\section{Sulfur}

Sulfur is a found in amino acids and is also a constituent of several coenzymes and vitamins (Taiz and Zeiger, 2010). Humus (soil organic matter) is the dominant reservoir for organic sulfur, which can be released through mineralization to $\mathrm{SO}_{4}{ }^{2-}$ and is principally lost due to leaching and runoff as well as easily volatilized (Sposito, 2008). 


\section{Calcium}

Plants use Ca for the synthesis of new cell walls along with mitotoic spindle during cell division (Taiz and Zeiger, 2010). Soil Ca bonds to soil particles and their abundance and bioavailability to plants is controlled by long-term weathering of minerals as well as $\mathrm{pH}$ and ligand type and concentration in soil solution (Essington, 2004).

\section{Magnesium}

Magnesium is the coordinating ion of the porphyrin structure of a chlorophyll molecule and maintains a steric configuration (Fraústo da Silva and Williams, 1991; Epstein and Bloom 2005; Taiz and Zeiger, 2010). Mg is a vital mineral nutrient through its role in activating more enzymes (e.g. such as enzymes needed for respiration, nucleic acid synthesis, and many photosynthetic reactions) than any other element (Epstein and Bloom, 2005). Soil Mg concentrations heavily depend on mineralogy, long-term weathering, as well as $\mathrm{pH}$ (Essington, 2004).

\section{Potassium}

Potassium plays a role in the activating enzymes involved in respiration and photosynthesis (Taiz and Zeiger, 2010). Potassium is also known for its role in regulating the osmotic potential of plant cells (Taiz and Zeiger, 2010). Just like with Ca and Mg, plant available $\mathrm{K}$ is controlled by long-term weathering of minerals as well as $\mathrm{pH}$ and ligand type and concentration in soil solution (Essington, 2004).

\section{Manganese}

Manganese is essential for the activation of several enzymes in the plant, specifically the enzymes involved in the Krebs cycle (Taiz and Zeiger, 2010). Mn is also controlled by soil mineralogy, long-term weathering, and pH conditions (Essington, 2004). 


\section{Chlorine}

Chlorine is responsible for the water splitting reaction in which $\mathrm{O}_{2}$ is produced during photosynthesis (Taiz and Zeiger, 2010). Cl availability is also controlled by long-term weathering, but unlike $\mathrm{Ca}, \mathrm{Mg}, \mathrm{K}$, and $\mathrm{P}$, it is negativity charged; thus, is easily lost in soil solution or through the atmosphere. Sea spray, aerosol deposition of nutrients, can be rich in $\mathrm{Cl}$, $\mathrm{Na}, \mathrm{Mg}, \mathrm{Ca}$, and S (White, 2009).

\section{Phosphorus}

Elemental phosphorus is extremely reactive and commonly bonds to four oxygen atoms resulting in phosphate $\left(\mathrm{PO}_{4}{ }^{3-}\right)$ and plants strictly take up phosphorus in the form of $\mathrm{PO}_{4}{ }^{3-}$ (Busman et al., 2002). Therefore plant available $\mathrm{P}$ always refers to the compound $\mathrm{PO}_{4}{ }^{3-}$. $\mathrm{P}$ is especially important in plants for synthesis of nucleic acids, sugar phosphates, and phospholipids (Taiz and Zeiger, 2010). Dissolved $\mathrm{PO}_{4}{ }^{3-}$ is produced through the mineralization of humus and the dissolution of $\mathrm{PO}_{4}{ }^{3-}$ from adsorption to solid particles like clay (Sposito, 2008). There are three main soil $\mathrm{P}$ pools: solution $\mathrm{P}$, active $\mathrm{P}$, and fixed $\mathrm{P}$ (Busman et al., 2002). $\mathrm{P}$ in solution includes plant available $\mathrm{P}$ as $\mathrm{PO}_{4}{ }^{3-}$, which is mobile in solution. $\mathrm{P}$ in solution can be depleted through plant uptake and is considered the smallest of the P pools in soils (Busman et al., 2002). Active $\mathrm{P}$ is instead bonded to the soil (not in solution) by being adsorbed to small soil particles such clays or organic compounds, or as $\mathrm{PO}_{4}{ }^{3-}$ salts of $\mathrm{Ca}$, or $\mathrm{Al}$. Active $\mathrm{P}$ can replace depleted $\mathrm{P}$ in solution through equilibrium and is the main and larger source of $\mathrm{P}$ for crops. Fixed $\mathrm{P}$ commonly refers to $\mathrm{P}$ mostly locked within crystalline structures as inorganic $\mathrm{PO}_{4}{ }^{3-}$. To determine $\mathrm{P}$ concentrations in soil, it is vital to understand soil mineralogy, organic matter, as well as $\mathrm{P}$ nutrient cycling. Some conversion of fixed $\mathrm{P}$ to active $\mathrm{P}$ can occur in soil through 
weathering and chemical processes (Busman et al., 2002). $\mathrm{PO}_{4}{ }^{3-}$ concentrations in solution are affected by soil erosion and by soil additions (inorganic and organic).

\section{Nitrogen}

Nitrogen is the macronutrient used in the highest concentrations, and is typically an ultimate limiting nutrient in soil alongside P. N plays an essential role in plant vitality by its use in the formation of proteins, enzymes, coenzymes, nucleic acids, chlorophyll, ATP, NADPH, and vitamins (Wermelinger, 1991). $\mathrm{N}$ takes as many as nine different forms corresponding to different oxidative states, but this research focuses on six different forms: $\mathrm{NO}_{3}{ }^{-}, \mathrm{NO}_{2}{ }^{-}, \mathrm{N}_{2}, \mathrm{NH}_{3}$, $\mathrm{NH}_{4}{ }^{+}$, and organic $\mathrm{N}$. While dinitrogen gas $\left(\mathrm{N}_{2}\right)$ comprises $\sim 79 \%$ of our atmosphere, it is not usable by most organisms, and only becomes available through $\mathrm{N}_{2}$-fixation by selected freeliving or symbiotic prokaryotes (Robertson and Groffman, 2015). There are four important soil nitrogen transformations in the $\mathrm{N}$-cycle mediated by these soil microbes: $N$ mineralization, $N$ immobilization, Nitrification, and Denitrification.

$N$ mineralization is mediated by soil micro-organisms, primarily fungi and bacteria, that are excellent at converting organic detritus into more plant available forms. Just like all other organisms, microbes require $\mathrm{N}$. If the organic detritus they consume is rich in $\mathrm{N}$ (low $\mathrm{C}: \mathrm{N}$ ratio), they release mineralized $\mathrm{N}$ as by-products, thus converting organic $\mathrm{N}$ forms such as detritus into inorganic forms such as $\mathrm{PO}_{4}{ }^{3-}$ which are more available to plants and microbes (Robertson and Groffman, 2015). Conversely, if the detritus they consume is low in N (high C:N ratio), their byproducts will be low in $\mathrm{N}$ thus withholding $\mathrm{N}$ within their own biomass leading to relative $N$ immobilization (Robertson and Groffman, 2015). N mineralization and $\mathrm{N}$ immobilization can occur at the same time within a soil depending on the type of organic detritus being consumed. 
Nitrification is the microbial oxidation of $\mathrm{NH}_{3}$ or $\mathrm{NH}_{4}^{+}$, into less reduced forms, e.g., $\mathrm{NO}_{2}{ }^{-}$and $\mathrm{NO}_{3}{ }^{-}$(Robertson and Groffman, 2015). Nitrification rates are driven by the concentration of $\mathrm{NH}_{4}{ }^{+}$in the soil, which is directly related to rates of $\mathrm{N}$ mineralization and $\mathrm{N}$ immobilization. $\mathrm{NH}_{3}$ and $\mathrm{NH}_{4}{ }^{+}$are in a pH-dependent equilibrium; under lower $\mathrm{pH}, \mathrm{NH}_{4}{ }^{+}$ dominates but may also be trapped in CEC sites such as soil organic matter, and charged clay surfaces while $\mathrm{NH}_{3}$ can be lost to volatilization or leaching (Robertson and Groffman, 2015). Because of their incapability to bond to soil particles (CEC, organic matter, and clay), anionic compounds $\mathrm{NO}_{2}{ }^{-}$and $\mathrm{NO}_{3}{ }^{-}$in soil solution are easily lost via gravitational processes and leaching (Robertson and Groffman, 2015). These compounds are also susceptible to denitrification (Robertson and Groffman, 2015). When N mineralization rates are high, nitrification will be elevated but higher $\mathrm{N}$ immobilization will reduce nitrification. Availability of $\mathrm{NO}_{3}{ }^{-}$tends to exceed $\mathrm{NH}_{4}{ }^{+}$in well aerated and temperate soils due to increased aerobic microbial activity and elevated nitrification (Epstein and Bloom, 2005; Sposito, 2008).

Denitrification is the process of reducing soil nitrates to $\mathrm{N}$ gases such as $\mathrm{NO}, \mathrm{N}_{2} \mathrm{O}$, and $\mathrm{N}_{2}$ (Robertson and Groffman, 2015) then this gaseous $\mathrm{N}$ is readily lost to the atmosphere (Sposito, 2008).

\section{Plant N Uptake and Assimilation}

Plants will take up $\mathrm{N}$ from the soil as $\mathrm{NH}_{4}{ }^{+}, \mathrm{NO}_{3}{ }^{-}$, but also possibly as dissolved organic $\mathrm{N}(\mathrm{DON})$, or as surface-sorbed $\mathrm{NH}_{4}$ on DON. Between $\mathrm{NH}_{4}{ }^{+}$and $\mathrm{NO}_{3}{ }^{-}, \mathrm{NH}_{4}{ }^{+}$is the preferred inorganic $\mathrm{N}$ source as it may take less energy to metabolize and concentrations vary less both seasonally and spatially than $\mathrm{NO}_{3}{ }^{-}$(Wermelinger, 1991: Epstein and Bloom, 2005; Sposito, 2008). In order for a plant to take up $\mathrm{NO}_{3}{ }^{-}$or $\mathrm{NH}_{4}{ }^{+}$into root cells, there must be the right ion and charge balance and cells can efflux $\mathrm{H}^{+}$to maintain ion uptake across the root cell membrane 
(Epstein and Bloom, 2005). Once plants take up $\mathrm{N}_{\text {as }} \mathrm{NO}_{3}{ }^{-}$and/or $\mathrm{NH}_{4}{ }^{+}$through their roots, plant cells assimilate the $\mathrm{N}$ into amino acids (Epstein and Bloom, 2005). The first critical step in assimilation is reduction of $\mathrm{NO}_{3}{ }^{-}$to $\mathrm{NO}_{2}{ }^{-}$, which involves nitrate reductase activity then nitrite reductase mediates production of ammonium and glutamine synthetase transforms the $\mathrm{NH}_{4}{ }^{+}$into organic compounds as the amino acid glutamine (Wermelinger, 1991). Overall, amino acids are made from glutamine and used for protein synthesis as well as synthesis of important molecules such as chlorophyll (Wermelinger, 1991). In grapevines, $\mathrm{N}$ is primarily stored, particularly during winter, as the amino acid arginine, which can be remobilized at the beginning of spring vegetative growth in the grapevine (Wermelinger, 1991). Grapevine stem samples were collected for this research during the veraison stage when the grapevine is heavily dependent on $\mathrm{N}$ reserves from within the plant system (Wermelinger, 1991).

\section{Grapevine Micronutrients}

Micronutrient elements necessary for plant growth include $\mathrm{Fe}, \mathrm{Zn}, \mathrm{Cu}, \mathrm{B}$, and $\mathrm{Mo}$ (White, 2009). Other micronutrients include Ni and V (Taiz and Zeiger, 2010). Micronutrients form insoluble compounds and bond strongly to mineral particles and organic matter, therefore are typically less mobile in soils for plant nutrient uptake (Essington, 2004). Micronutrients are found in minerals and organic matter and become plant available through weathering of parent mineral to form soil solutions as well as organic chemical transformations (Sposito, 2008).

Plant available metallic elements $\mathrm{Fe}, \mathrm{Cu}, \mathrm{Zn}, \mathrm{Mo}$, and Ni tend to be more plant available at low $\mathrm{pH}$ and are readily absorbed by clays (White, 2009). These metallic elements are important for electron transfer and energy transformations and precipitate as insoluble hydroxides as $\mathrm{pH}$ increases, with the exception of Mo, which is not affected by an increase in $\mathrm{pH}$ (White, 2009; Taiz and Zeiger, 2010).

Iron is essential for the transfer of electrons in enzymes, and can be oxidized from $\mathrm{Fe}^{2+}$ to 
$\mathrm{Fe}^{3+}$ and reduced back to $\mathrm{Fe}^{2+}$ as a transition metal (Taiz and Zeiger, 2010). Copper, like Fe, is associated with the transfer of elections in enzymes and redox reactions oxidizing from $\mathrm{Cu}^{2+}$ to $\mathrm{Cu}^{3+}$ (Taiz and Zeiger, 2010). Zinc is required for some enzyme activity and may be required for chlorophyll biosynthesis (Taiz and Zeiger, 2010). Molybdenum is a component of several enzymes including nitrate reductase and bacterial nitrogenase (Taiz and Zeiger, 2010).

Molybdenum (Mo) is typically found in soil as an anion molybdate $\left(\mathrm{MoO}_{4}{ }^{2-}\right)$, and is strongly adsorbed to Fe and $\mathrm{Al}$ oxides at low pH (White, 2009). Unlike other metals, it becomes it becomes more available as $\mathrm{pH}$ increases (White, 2009). Nickel is used for the enzyme urease and is also used by nitrogen-fixing organisms (Taiz and Zeiger, 2010).

The role of boron in plant functions is seemingly unclear but it is suggested that it plays a role in cell elongation, nucleic acid synthesis, hormone response, membrane function, and cell cycle regulation (Taiz and Zeiger, 2010). Soil boron commonly occurs as boric acid $\left(\mathrm{H}_{3} \mathrm{BO}_{3}\right)$ until it reaches a $\mathrm{pH}$ greater than 8 , where it then begins to dissociate and releases the borate anion $\mathrm{B}(\mathrm{OH})_{4}^{-}$, which is weakly absorbed by oxides (White, 2009).

\section{Nitrogen Isotopes: Biological Tracer}

Nitrogen has two naturally occurring stable isotopes and because $\mathrm{N}$ is essential to metabolic processes, it is uniquely suited as a biologic tracer to understand nutrient cycling across ecosystems (Pardo and Nadelhoffer, 2010). Fractionation occurs between ${ }^{15} \mathrm{~N}$ and ${ }^{14} \mathrm{~N}$ during physical, enzymatic, and other biological processes (Pardo and Nadelhoffer, 2010). Fractionation, especially enzymatic fractionation, naturally favors the lighter isotope ${ }^{14} \mathrm{~N}$, and discriminates against the heavier isotope, ${ }^{15} \mathrm{~N}$ (Pardo and Nadelhoffer, 2010). In other words, samples with more negative $\delta^{15} \mathrm{~N}$ values would suggest an increased rate of fractionation, due to 
discrimination against the heavier isotope via enzymatic reactions, compared to samples with a more positive $\delta^{15} \mathrm{~N}$ values. 


\section{STUDY RATIONALE}

While the DOCs of Jesi and Matelica are located less than $50 \mathrm{~km}$ apart and have minor climate variations, they consistently produce Verdicchio contrasting in wine flavor. Because of this well documented wine dichotomy (Bastianich and Lynch, 2002), I speculated that minor climatic variations and anthropogenic controls instrumented by the winemaking process are minimal, and that instead geological variations significantly contribute to wine characteristics. This research specifically addresses the potential role of geology, as it relates to soil-grapevine interactions and plant metabolic processes, exploring the Verdicchio wine flavor dichotomy between the DOCs of Jesi and Matelica.

I aimed to evaluate geological and biological variations in Jesi and Matelica on three levels:

1. Soil: Determine if there are geological variations. Soil variations will be characterized based on soil chemistry and composition through the selected analyses of soil texture, $\mathrm{pH}$, organic matter, mineralogy, elemental and oxide concentrations, element concentrations $(\mathrm{N}, \mathrm{C}$, and $\mathrm{P})$, base saturation, cation exchange capacity, and plant available nutrients $\left(\mathrm{NO}_{3}{ }^{-}\right.$and $\left.\mathrm{PO}_{4}{ }^{3-}\right)$.

2. Grapevine stems: Determine if there are chemical variations in grapevine stems. Grapevine stems were analyzed for elemental concentrations of N, C, and P.

3. Soil-Grapevine Stem Interactions: Biological variations (rates of both amino acid synthesis in grapevine stems and microbial metabolism in soil) were interpreted through $\mathrm{N}$ isotopes. The number of $\mathrm{N}$ turnovers was then calculated using soil and grapevine stem $\mathrm{N}$ isotopic ratios in order to understand $\mathrm{N}$ cycling within individual plants throughout the growing season. Soil and grapevine stem N, C, and P concentrations were compared to quantify soil-plant nutrient interactions. Grapevine stem $\mathrm{N}$ and $\mathrm{P}$ concentrations were 
further compared to soil plant available nutrients $\left(\mathrm{NO}_{3}{ }^{-}\right.$and $\left.\mathrm{PO}_{4}{ }^{3-}\right)$. 


\section{METHODS}

Soil and grapevine stem samples were collected 22-27 July, 2016. This study was conducted at four vineyards in each DOC consisting of the excavation of one soil profile in each vineyard. One vineyard from each DOC was selected for the excavation of two soil profiles. The excavation of two soil profiles in one vineyard was originally executed to understand how soils were impacted when cultivated next to grapevines varying in age. Unfortunately, this was analysis was not able to be determined. This study focused on soil samples collected within eight vineyards and a total of ten soil profiles. Soil samples were collected at consistent depths of 3 , 10,25 , and $50 \mathrm{~cm}$ in each soil profile to avoid soil horizon inconsistencies due to geomorphologic variations. Grapevine stems were collected next to each soil profile and stripped of bark, leaving only woody plant tissue, which was then left to air dry. Soil samples were collected and left to air dry within 12 hours of sampling. The soil depth of $10 \mathrm{~cm}$ will be the focus depth of many analytical tests as it represents the zone of plant nutrient acquisition. A complete list of vineyard names, locations, soil profiles, as well as sample names can be found in Appendix-A, as samples will be referred to as Jesi or Matelica soil profiles 1, 2, 3, 4, and 5 . GIS

A digital elevation model (DEM) of the Italian provinces Ancona and Macerata, located in the Marche Region, were attained through Tarquini et al., 2007 and Tarquini et al., 2012 and were stitched together in a mosaic and projected to WGS_1984_UTM_Zone_32N. A clip of each DOC was created by extracting the DOC shape of both Jesi and Matelica through Corel draw using figure 4 in Conte et al., 2006. Each DOC clip was georeferenced using easily identifiable reference points to obtain the best possible fit. A polygon was extracted and used to clip both DOCs to calculate elevation, slope, and aspect. 


\section{Statistics}

Differences between parameters of soil and grapevine stems between Jesi and Matelica were examined using 1-way ANOVA in Sigmaplot (v12.5, Systat Software Inc, San Jose, CA, USA) using $\mathrm{p}<0.05$ as significant.

\section{Grain Size: Malvern Mastersizer 2000E}

Particle-size soil analysis was conducted on each soil profile at all sampling depths (3, $10,25,50 \mathrm{~cm}$ ). Each soil sample was dispersed in $20 \mathrm{~mL}$ of deflocculant (sodium metaphosphate $\left(\mathrm{NaPO}_{3} 50 \mathrm{~g} / \mathrm{L}\right)$, sonicated for 1 minute, and analyzed on a Malvern Mastersizer 2000E following Sperazza et al. (2004). For each sample, soil grainsize classes were extracted and expressed in an overall percent notation (i.e. sand, silt, and clay). These values were then put into the United States Department of Agriculture (USDA) soil texture calculator to determine overall soil texture for each soil sample by plotting in a soil texture triangle.

pH

Soil samples were analyzed for $\mathrm{pH}$ by Ward Laboratories in Kearney, Nebraska according to Ward Laboratory (2014c). Soil pH was measured through the activity of ionized $\mathrm{H}^{+}$ in solution through a Ross Sure-Flow reference electrode and recorded based on a 1:1 soil:water ratio.

\section{Organic Matter \%LOI}

Soil samples were analyzed by Ward Laboratories in Kearney, Nebraska on October $10^{\text {th }}$, 2016 according to Ward Laboratory (2014d). Soil samples were dried at $105^{\circ} \mathrm{C}$ for 2 hours and once cooled, a random sample was collected using a 2 g scoop and placed in pre-weighed crucibles. Sample was then combusted in a muffle-furnace at $360^{\circ} \mathrm{C}$ for 2 hours. Samples were 
then re-weighed and calculations were conducted in order to determine Loss On Ignition (\%LOI) (i.e. organic matter) using equation 1.

$$
\text { Equation 1: } \% L O I=\frac{(\text { dry weight }- \text { ashed weight })}{\text { dry weight }} \times 100
$$

\section{Mineralogy (XRD)}

Approximately $3 \mathrm{~g}$ of individual soil samples were weighed and dried in a drying oven at $\sim 100^{\circ} \mathrm{C}$. Once dried, soils were powdered using a tungsten carbide Rocklab Shatterbox. A D8 Focus X-Ray Diffractometer (XRD) was used to determine the mineral assemblages at a constant soil depth at $10 \mathrm{~cm}$ for each sample. Powdered samples were mounted randomly to avoid preferred orientation of the mineral grains. The XRD patterns were evaluated using Bruker's EVA software and compared against the ICDD PDF2 to identify peaks. Because if soil heterogeneity and mineral transformations and degradations, quantitative mineralogical concentrations could not be determined, thus only semi-quantitate abundances were obtained on the XRD.

\section{Elemental and Oxide Concentrations (XRF)}

Approximately $3.0 \mathrm{~g}$ of individual soil samples were weighed and dried in a drying oven at $\sim 100^{\circ} \mathrm{C}$. Once dried, soils were powdered using a tungsten carbide Rocklab Shatterbox. Samples were weighed on an analytical balance to $1.0000 \mathrm{~g}(+/-0.0003)$ and placed in dry preweighed crucibles and combusted in a muffle-furnace at $1050^{\circ} \mathrm{C}$ for 15 minutes and then reweighed in order to determine \%LOI (organic matter) using equation 1.

Glass beads were fused using a Claisse M4 Fluxer with a ratio of 1.1:11, $1.1000 \mathrm{~g} \mathrm{(+/-}$ 0.0003) of soil mixed with $11.0000 \mathrm{~g}$ (+/- 0.0003) of a 50/50 LiT/LiM lithium borate flux as well as with a lithium bromide non-wetting agent and $1.0000 \mathrm{~g}(+/-0.0003)$ of ammonium nitrate. The glass bead was then analyzed using a Bruker S4 Pioneer X-Ray Fluorescence (XRF) 
spectrometer to measure major, minor, and a few trace element concentrations in units wt $\%$ or ppm. Elemental abundances were calculated using a calibration curve based on 11 USGS rock standards, following the methods of McHenry (2009).

\section{Cation Exchange Capacity and Base Saturation}

Soil samples were analyzed for CEC and base saturation by Ward Laboratories (2014a). The net negative charge amongst soil particles influences the amount of cation (typically plant nutrients) concentration and retention. The net negative soil charge is known as cation exchange capacity (CEC). The more negatively charged soil particles (organic matter and fine grained soil particles), the higher the CEC, therefore, the more positivity charged nutrients a soil can retain. CEC is expressed in milliequivalents per $100 \mathrm{~g}$ of soil (me/100g). Base saturation refers to the percent concentration of cations $\left(\mathrm{Mg}^{2+}, \mathrm{K}^{+}, \mathrm{Ca}^{2+}\right.$, and $\left.\mathrm{Na}^{+}\right)$released within sites of negatively charged soil particles (CEC). In order to determine cation concentrations, cations are released from CEC sites by using an extraction solution of $1 \mathrm{~N}$ ammonium acetate. The cation $\left(\mathrm{NH}_{4}^{+}\right)$is then exchanged with cations originally bonded within negatively charged soil particle, thus releasing cations into the extraction solution. The known concentration of the extraction solution is then analyzed using an Inductively Couple Argon Cooled Plasma Spectrometer (ICAP) calculating base saturation, percent at concentration based on 100g of soil, as well as CEC.

\section{Elemental Analyzer: Nitrogen and Carbon}

Soil and grapevine stem samples were analyzed for $\mathrm{C}$ and $\mathrm{N}$ elemental content using an elemental analyzer (Flash EA1112 CE Elantech) following procedures by Bott et al. (2008). Grapevine stem samples were weighed at $\sim 5 \mathrm{mg}$ and encapsulated in tin boats ready for combustion. However, soil samples first had to be prepped to remove carbonate material to detract from $\mathrm{C}$ cross contamination. Soil were acid-washed in $0.1 \mathrm{~N} \mathrm{HCl}$, rinsed with de-ionized 
water, and filtered. Once dried, soil samples were weighed at 20 mg and encapsulated in tin boats for combustion.

\section{Total Phosphorus Content}

Total phosphorus content procedures were conducted according to Young et al. (2010) modified from Stainton et al. (1974). Soil and grapevine samples were baked in a muffle furnace at $500^{\circ} \mathrm{C}$ for 2 hours in acid-washed test tubes. Ashed samples were combined with $12.5 \mathrm{~mL}$ of MQ $\mathrm{H}_{2} \mathrm{O}$ and $2.5 \mathrm{~mL}$ of $1 \mathrm{M} \mathrm{HCl}$. Phosphate standards were also prepared over the range 0-24 $\mu \mathrm{M}$. Samples and standards were then autoclaved at $120^{\circ} \mathrm{C}$ for 30 minutes, cooled and assayed for soluble molybdate-reactive phosphorus and read at $850 \mathrm{~nm}$ in a spectrophotometer (Parsons et al. 1984). Absorbance at $850 \mathrm{~nm}$ values for standards were plotted extracting a unique linear regression, thus deriving the equation used to convert sample Absorbance at $850 \mathrm{~nm}$ to $\mathrm{PO}_{4}{ }^{3+}$ concentration.

\section{Analysis for Plant Available Nutrients: Nitrate and Phosphorus}

Nitrate

Soil samples were analyzed for Nitrate by Ward Laboratories (2012). $\mathrm{NO}_{3}{ }^{-}$was the plant available form of $\mathrm{N}$ analyzed in this research. Calcium phosphate $(500 \mathrm{ppm})$ was used as an extraction solution, extracting $\sim 5 \mathrm{~g}$ of sample of soil solution, which was then analyzed using a Lachat FIA analyzer. Nitrate was reduced to nitrite by passing the sample through a column of copperized cadmium. Nitrite is then identified by reaction with sulfanilamide followed by N-(1naphyl) ethylenediamine dihydrochloride and absorbance read at a wavelength of $520 \mathrm{~nm}$ (Ward Laboratory, 2012). 
Phosphorus: Olsen Phosphorus Method

Soil samples were analyzed for plant available P using the Olsen method by Ward Laboratories (2014b). Olsen Phosphorus Method is a Sodium Bicarbonate extraction method and was established for soil calcareous in nature, specifically soils with $2 \%$ or more calcium carbonate (Frank et al., 1998; Ward Laboratory, 2014e). Procedures consist of 1g of soil combined with $20 \mathrm{~mL}$ of $0.5 \mathrm{~N} \mathrm{NaHCO}_{3}$ extracting solution adjusted to a $\mathrm{pH}$ of 8.5. This solution is then shaken for 30 minutes and filtered and then compared to standard curves using a Lachat QuickChem at a wavelength of $880 \mathrm{~nm}$.

\section{Nitrogen Isotopes}

Soil and grapevine stem samples were analyzed for $\mathrm{N}$ isotopes at the UC-Davis University of California Stable Isotope Facility using procedures documented on their website under Analytical Services: Carbon and Nitrogen in Solids titled Carbon $\left({ }^{13} \mathrm{C}\right)$ and Nitrogen $\left({ }^{15} \mathrm{~N}\right)$ Analysis of Solids by EA-IRMS (UC Davis Stable Isotope Facility, 2017). Encapsulated samples were combusted and isotopically analyzed for $\mathrm{N}_{2(\mathrm{~g})}$ via an Elementar Vario Micro elemental analyzer that is interfaced to a PDZ Europa 20-20 IRMS isotope ratio mass spectrometer (IRMS) operating in continuous flow with an open-split gas-handling peripheral. Grapevine samples produce less ash after combustion than soil samples. Therefore, for ease of sample processing, grapevine samples were analyzed using a PDZ Europa ANCA-GSL elemental analyzer interfaced to a PDZ Europa 20-21 IRSM while soil samples were analyzed using an Elementar Vario EL Cube elemental analyzer, which has a more rapid interface to exchange ash-filled quartz inserts in the combustion column, interfaced to a PDZ Europa 20-20 IRMS. Grapevine samples were combusted at $1000^{\circ} \mathrm{C}$ in a chromium oxide and silvered copper oxide packed reactor. Once combusted, oxides removed and placed in a reduction reactor comprised of 
reduced copper at $650^{\circ} \mathrm{C}$. Soil were combusted at $1080^{\circ} \mathrm{C}$ in a copper oxide and tungsten (VI) oxide packed reactor. Once combusted, oxides removed and placed in a reduction reactor comprised of reduced copper at $650^{\circ} \mathrm{C}$. Samples were run interspersed with several secondary and laboratory references including quality control references: peach leaves, enriched alanine, and nylon, and quality assurance references: glutamic acid data. Standards were selected based upon compositional similarity and previously calibrated against NIST Standard Reference Material. For the analysis period (March 2017) the results of the references are as follows: average peach leaves $\delta^{15} \mathrm{~N}+2.12 \pm 0.12 \%$ (known value $+1.95 \%$ ) ; average enriched alanine $\delta^{15} \mathrm{~N}$ $+41.13 \pm 0.20 \%$ (known value $+41.13 \%$ ); average nylon $\delta^{15} \mathrm{~N}-10.31 \pm 0.09 \%$ o (known value $10.3 \%$ ); average glutamic acid $\delta^{15} \mathrm{~N}-6.91 \pm 0.10 \%$ (known value $-6.8 \%$ ). All isotopic results are expressed in the conventional per mil $(\delta)$ notation $\delta=\left(\frac{R_{A}}{R_{B}}-1\right) 1000$, where $\mathrm{R}_{\mathrm{A}}$ is the isotopic ratio of the unknown, and $R_{B}$ is the isotopic ratio of a known reference material. Nitrogen isotope data is referenced against Air.

\section{Nitrogen Turnover}

In order to understand the potential differences in plant metabolic processes between Jesi and Matelica, the plant $\mathrm{N}$ turnover was simulated using a stable isotope-based progress-variable model (Cerling et al., 2007). The progress variable, F (Equation 2), defines the time-dependent conversion of stable isotopic compositions from some initial condition towards and equilibrium condition as time approaches infinity and has the following relationships (Cerling et al., 2007):

$$
\text { Equation 2: } F=\frac{\delta_{t}-\delta_{e q}}{\delta_{o}-\delta_{e q}}=e^{-\lambda t}
$$

where $\delta_{\mathrm{t}}, \delta_{\mathrm{eq}}$, and $\delta_{\mathrm{o}}$ are the delta values (or isotopic ratio, $\mathrm{R}$ ) at time of $\mathrm{t}$, at equilibrium, and at the initial condition, respectively. The rate constant is expressed as $\lambda$. 
For a situation in which more than one sink is present, we can re-express the progress variable equation to account for each sink and their characteristic $\mathrm{N}$ turnover in order to model the full system of source to multiple simultaneous sinks (Equation 3).

$$
\text { Equation 3: } \frac{\delta_{t}-\delta_{e q}}{\delta_{o}-\delta_{e q}}=\sum_{j}^{n} x_{i} e^{-\lambda_{i} t}=x_{1} e^{-\lambda_{1} t}+x_{2} e^{-\lambda_{2} t}+x_{3} e^{-\lambda_{3} t} \ldots x_{j} e^{-\lambda_{j} t}
$$

where $x$ is the fractional abundance of the $\mathrm{i}^{\text {th }}$ sink.

Boundary conditions of this model are the $\delta_{\text {eq }}$ and $\delta_{\mathrm{o}}$ terms, where $\delta_{\text {eq }}$ is the observed isotopic composition of grapevine stems, and the initial condition, $\delta_{\mathrm{o}}$, is the observed isotopic composition of soil. Conversion of delta notation $(\delta)$ to isotopic ratios $(\mathrm{R})$ was performed utilizing the definition of $\delta$ and the known isotopic ratio of $\mathrm{N}_{2(\mathrm{~g})}$ in Air, which is used as an international reference for $\mathrm{N}$ isotopes. Isotopic ratios were calculated to interpret the source to sink $\mathrm{N}$ interactions and are better used to analyze individual $\mathrm{N}$ complexities within soilgrapevine interactions. Characteristic rate constants for each sampled grapevine stem, $\boldsymbol{\lambda}$, was determined through an exponential regression on the modeled isotopic values bounded by our observed boundary conditions. The modeled isotopic values change in accord to the rate constants for a selection of amino acids (Finlay et al., 1988), and are thus only relevant for this ensemble of amino acid sinks. The characteristic rate constant $\lambda$ (hours ${ }^{-1}$ ) of individual grapevine stems were converted to the half-life, t1/2 (hours) (Equation 4).

$$
\text { Equation 4: } t_{1 / 2}=\frac{\operatorname{Ln}(2)}{\lambda}
$$

Since the grapevine stems were sampled at one timepoint during the growth season we lack observation of turnover and fluctuation of $\mathrm{N}$ over time. Thus, in order to better understand how these characteristic rate constants relate to actual productivity for a given grapevine, half- 
life was converted the number of $\mathrm{N}$ turnovers $(\boldsymbol{\tau})$ elapsed throughout the growing season based upon our observed boundary conditions (Equation 5):

Equation 5: $\tau=\frac{-\operatorname{Ln}\left(\frac{N_{(t)}}{N_{(o)}}\right)}{\frac{\operatorname{Ln}(2)}{t_{1 / 2}}}$ 


\section{RESULTS}

\section{Soils}

\section{Texture, pH, Organic Matter Content}

Jesi soil profile 1 was texturized as slightly more coarse in soil texture (silt loam) compared to counterpart vineyards, which were texturized as silt (Appx. B). Similarly, Matelica soil profiles 4 and 5 were texturized as silt loam compared to counterpart vineyards, which were texturized as silt (Appx. C). Jesi and Matelica shared similar soil $\mathrm{pH}(p>0.05)$ at the depth of $10 \mathrm{~cm}$ in depth with Jesi at a $\mathrm{pH}$ of $8.36 \pm 0.21$ and Matelica at a $\mathrm{pH}$ of $8.26 \pm 0.11$. However, soil organic matter at $10 \mathrm{~cm}$ depth was significantly different between the DOCs $(p=0.001)$ with $3.42 \pm 0.72 \%$ in Matelica and $1.80 \pm 0.21 \%$ in Jesi. There was a negative correlation between soil pH and organic content within each DOC (Fig. 3); as organic matter increased, soil pH decreased and Jesi exhibited a more negative slope than Matelica. See Appendix D for a complete list of Jesi and Matelica vineyard $\mathrm{pH}$ and organic matter content.

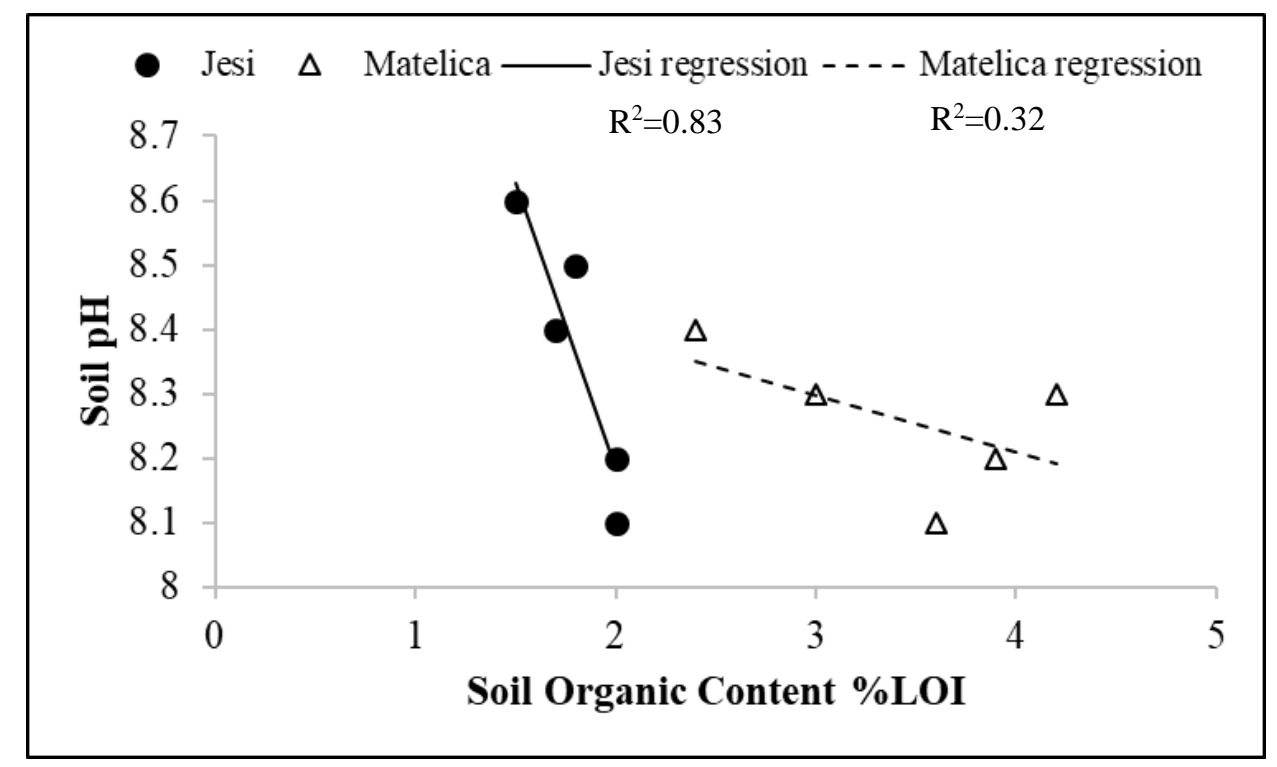

Figure 3: Relationship between soil $\mathrm{pH}$ and organic matter for Jesi and Matelica DOCs. Both DOCs exhibit a negative trend, but Jesi exhibits a more negative slope than Matelica. Lines fitted by linear regression. 


\section{Mineralogy, Elemental, and Oxide Concentrations}

Through semi-quantitative analysis, Jesi and Matelica were determined to have differences in mineralogical compositions and concentrations at a soil depth of $10 \mathrm{~cm}$, with the most critical difference noted in dolomite abundances. Jesi vineyard soils, with the exception of soil profile 1, were determined to have dolomite $\left(\mathrm{CaMg}\left(\mathrm{CO}_{3}\right)_{2}\right)$, whereas Matelica vineyards were determined to be all lacking dolomite (Table 2). Jesi vineyards had higher concentrations of calcite $\left(\mathrm{CaCO}_{3}\right)$ and albite $\left(\mathrm{NaAlSi}_{3} \mathrm{O}_{8}\right)$ than Matelica (Table 2). However, Matelica soil

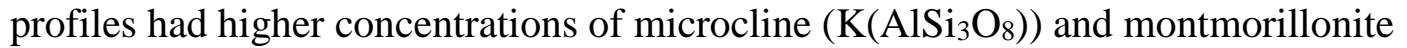
$\left((\mathrm{Na}, \mathrm{Ca})_{0.33}(\mathrm{Al}, \mathrm{Mg})_{2}\left(\mathrm{Si}_{4} \mathrm{O}_{10}\right)(\mathrm{OH})_{2} \bullet \mathrm{nH}_{2} \mathrm{O}\right)$ in comparison to Jesi soil profiles (Table 2). A complete table of mineral assemblages determined by XRD can be found in Appendix $\mathbf{E}$.

Soil elemental and oxide concentrations were determined using XRF in units wt\% (Fig. 4A) and ppm (Fig. 4B). A complete list of Jesi and Matelica soil profile elemental and oxide concentrations can be found in Appendices F, G, H, I. Mean elemental and oxide concentrations as well as 1-way ANOVA tests can be found in Appendix J. Only one oxide and two elemental concentrations were found to be significantly different between DOCs; $\mathrm{MnO} p p m(p=0.008)$, Co ppm ( $p=0.031)$, and V ppm ( $p=0.048)$ (Fig. 4B and Appx. J). Soil mineralogy influences both elemental and oxide concentrations, which highlights higher concentrations of $\% \mathrm{CaO}$ (Fig. 4A) and \% $\mathrm{MgO}($ Fig. 4A and 5) in Jesi, consistent with respective higher calcite and dolomite abundances analyzed in XRD (Table 2). Mean Jesi $\% \mathrm{CaO}$ and $\% \mathrm{MgO}$ were $16.3 \pm 0.045 \%$ and $2.46 \pm 0.012 \%$ in comparison to Matelica at $11.0 \pm 0.075 \%$ and $1.46 \pm 0.0020 \%$, respectively.

Specifically, Jesi soil profiles 4 and 5 were measured to have increased $\% \mathrm{MgO}$ concentrations compared to other Jesi vineyards. These higher $\% \mathrm{MgO}$ concentrations correlate with XRD data, which showed that Jesi soil profiles 4 and 5 were also the soil profiles that had 
the highest dolomite abundances. A similar correlation can be noted in Jesi soil profiles 1, which was the only soil profile in the DOC of Jesi that lacked dolomite, mimicking $\% \mathrm{MgO}$ concentrations in Matelica. Elements with statistical errors $>12 \%$ or with concentrations less than two times the Lower Limits of Detection are labeled as Not Detected (ND).

This is also consistent with higher $\% \mathrm{Mg}$ base saturation concentrations in Jesi (Table 3). Matelica was also found to have an average $\% \mathrm{SiO}_{2}$ concentration of $53.6 \pm 0.090 \%$, higher than that of Jesi at $46.4 \pm 0.077 \%$ (Appx. J).

Table 2: Select semi-quantitative mineralogy abundances for both Jesi and Matelica at a soil depth of $10 \mathrm{~cm}$. Determined using XRD.

\begin{tabular}{|c|c|c|c|c|c|}
\hline Soil Profiles & Calcite & Dolomite & Microcline & Albite & Montmorillonite \\
\hline \multicolumn{6}{|l|}{ Jesi } \\
\hline 1 & XXX & - & $\mathrm{XX}$ & $\mathrm{XX}$ & $\mathrm{X}$ \\
\hline 2 & XXX & $\mathrm{X}$ & $\mathrm{X}$ & $\mathrm{XX}$ & $\mathrm{X}$ \\
\hline 3 & $\mathrm{XXX}$ & $\mathrm{X}$ & $\mathrm{XX}$ & $\mathrm{XX}$ & - \\
\hline 4 & $\mathrm{XXX}$ & $\mathrm{XX}$ & - & $\mathrm{XX}$ & - \\
\hline 5 & XXX & $\mathrm{XX}$ & - & $\mathrm{XX}$ & - \\
\hline \multicolumn{6}{|l|}{ Matelica } \\
\hline 1 & XXX & - & $\mathrm{X}$ & $\mathrm{XX}$ & $\mathrm{X}$ \\
\hline 2 & $\mathrm{XX}$ & - & $\mathrm{X}$ & $\mathrm{X}$ & $\mathrm{X}$ \\
\hline 3 & $\mathrm{XX}$ & - & $\mathrm{X}$ & $\mathrm{X}$ & $\mathrm{X}$ \\
\hline 4 & $\mathrm{XXX}$ & - & $\mathrm{XX}$ & $\mathrm{X}$ & $\mathrm{X}$ \\
\hline 5 & - & - & $\mathrm{XX}$ & $\mathrm{X}$ & $\mathrm{X}$ \\
\hline
\end{tabular}

(xxx) High concentration; (xx) Moderate concentration; (x) Low concentration;

(-) None detected 

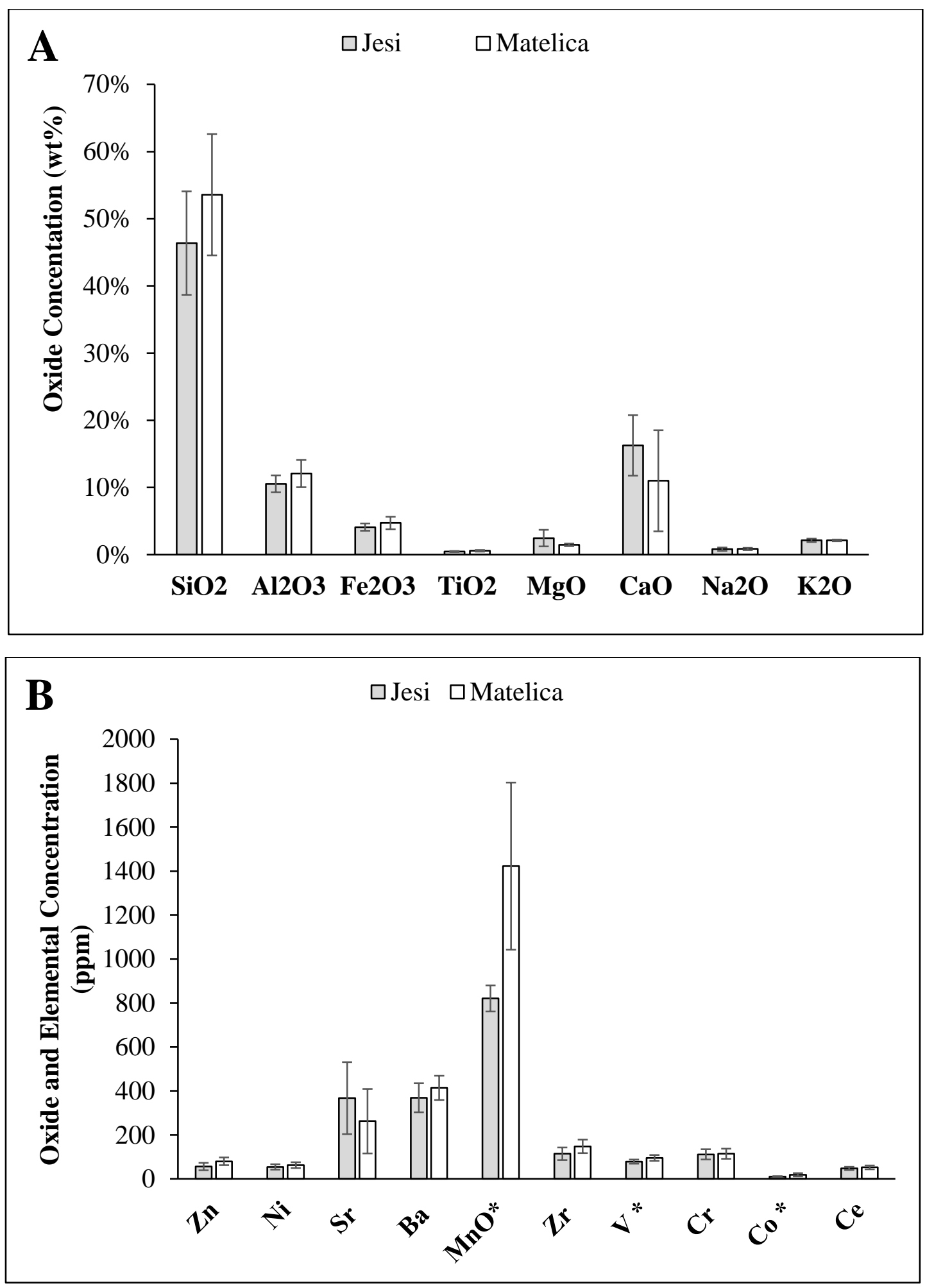

Figure 4: Elemental and oxide concentrations in Jesi and Matelica soils measured by XRF in units wt\% (A) and ppm (B). *MnO, * Co, and *V are statistically different between DOCs ( $p<0.05,1$-way ANOVA). Bars (+/- standard deviation) represent the average of 5 soil profile samples for each DOC. 


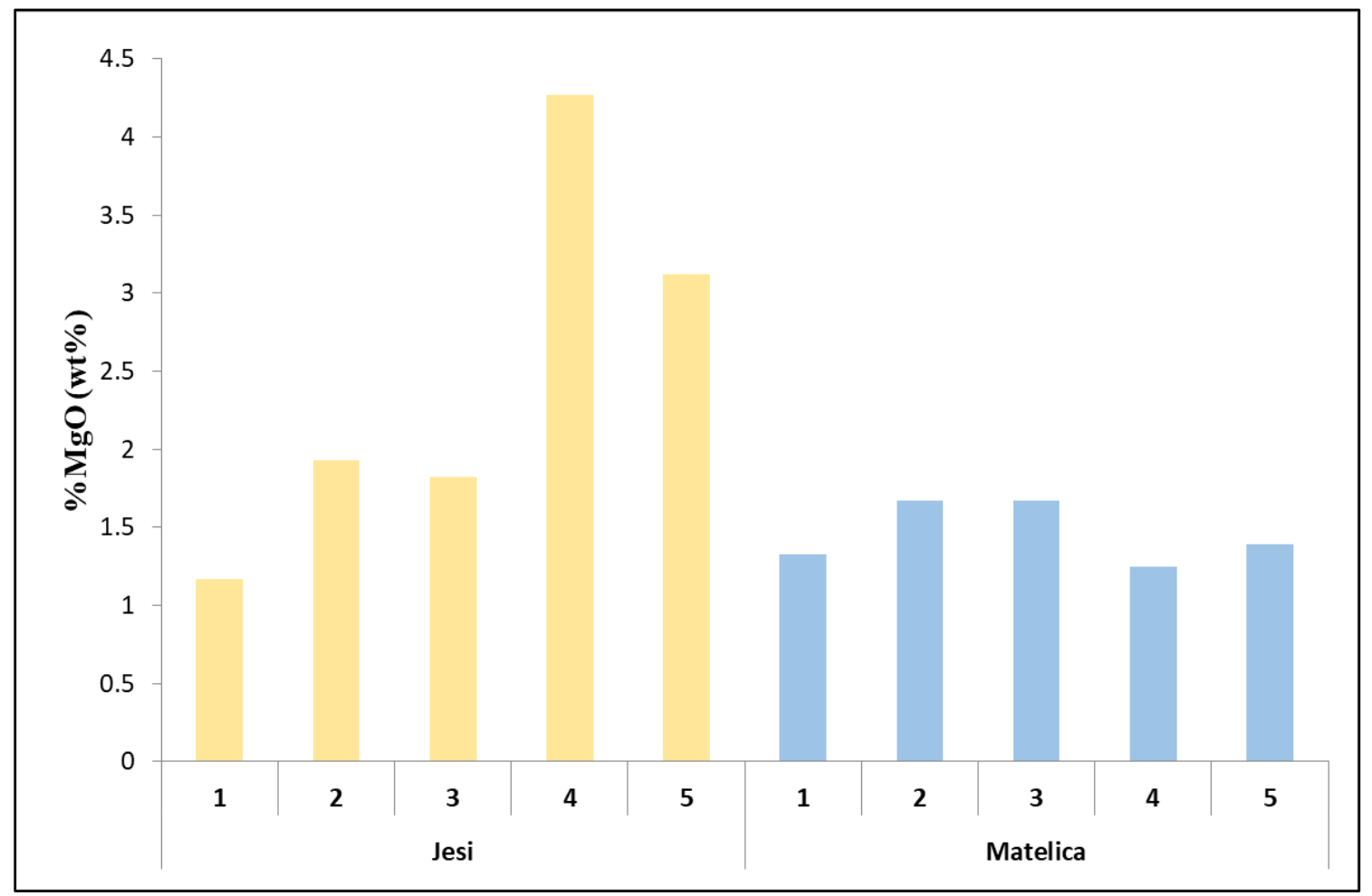

Figure 5: Soil \% MgO at $10 \mathrm{~cm}$ in depth for individual soil profiles in Jesi (yellow) and Matelica (blue).

\section{Base Saturation and CEC}

Variations in base saturation displays similar trends as in soil mineralogy (XRD) and elemental concentrations (XRF) (Table 3). A complete table of individual soil profile base saturation $(\% \mathrm{Mg}, \% \mathrm{~K}, \% \mathrm{Ca}$, and $\% \mathrm{Na})$ and $\mathrm{CEC}$ values can be found in Appendix $\mathrm{K}$. The $\% \mathrm{Mg}$ between DOCs was found to be significantly different $(p=0.025)$ with Jesi at a higher concentration at $8.8 \pm 3.63 \% \mathrm{Mg}$ compared to Matelica at $4.2 \pm 0.84 \% \mathrm{Mg}$. Other base saturation values $\% \mathrm{~K}, \% \mathrm{Ca}$, and $\% \mathrm{Na}$ were found to be less variable between DOCs $(p>0.05)$ (Table 3). CEC between DOCs were determined as almost significantly different $(\mathrm{p}=0.057)$ with Matelica

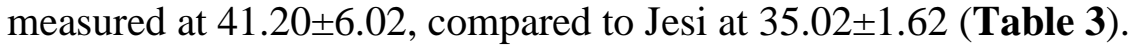


Table 3: Base saturation and CEC soil concentrations at $10 \mathrm{~cm}$ in depth between both DOCs. *\% Mg was significantly different between the DOCs (1-way ANOVA).

\begin{tabular}{|c|c|c|c|}
\hline Test & $\begin{array}{c}\text { Jesi } \\
\text { Mean }(S D)\end{array}$ & $\begin{array}{c}\text { Matelica } \\
\text { Mean }(S D)\end{array}$ & $p$-value \\
\hline Base Saturation $\% \mathrm{Mg}$ & $\begin{array}{c}8.8 \\
(3.63)\end{array}$ & $\begin{array}{c}4.2 \\
(0.84)\end{array}$ & $* 0.025$ \\
\hline Base Saturation \% K & $\begin{array}{c}4.2 \\
(1.48)\end{array}$ & $\begin{array}{c}4.4 \\
(0.89)\end{array}$ & 0.803 \\
\hline Base Saturation \%Ca & $\begin{array}{c}86.0 \\
(4.53) \\
\end{array}$ & $\begin{array}{c}90.4 \\
(0.89) \\
\end{array}$ & 0.066 \\
\hline Base Saturation $\% \mathrm{Na}$ & $\begin{array}{c}1.0 \\
(0.00)\end{array}$ & $\begin{array}{c}0.6 \\
(0.55)\end{array}$ & 0.086 \\
\hline CEC & $\begin{array}{l}35.02 \\
(1.62)\end{array}$ & $\begin{array}{l}41.20 \\
(6.02)\end{array}$ & 0.057 \\
\hline
\end{tabular}

Total N Content wt\% and Plant Available $\mathrm{NO}_{3}{ }^{-}{ }^{-}{ }^{4} \%$

Mean total soil $\mathrm{N}$ content was significantly different $(p=0.008)$ with higher concentrations in Matelica at $0.17 \pm 0.040 \mathrm{wt} \%$ than Jesi at $0.10 \pm 0.015 \mathrm{wt} \%$ (Table 4). However, plant available $\mathrm{NO}_{3}{ }^{-}$between DOCs was not significantly different $(p>0.05)$ (Table 4).

Furthermore, aside from soil profile 4 in Matelica, which has a plant available $\mathrm{NO}_{3}{ }^{-}$ concentration at $0.0158 \mathrm{wt} \%$, Jesi and Matelica have very similar plant available $\mathrm{NO}_{3}{ }^{-}$ concentrations (Fig. 6, Table 4, and Appx. N).

Soil $\mathrm{N}$ content was also noted to show a positive correlation with organic matter in both DOCs (Fig. 7A). Refer to Appendices $\mathbf{L}$ and $\mathbf{M}$ for a complete list of soil $\mathbf{N}$ concentrations for Jesi and Matelica at each soil depth within soil profiles. 
Table 4: Soil macronutrient content and plant available $\mathrm{N}$ and $\mathrm{P}$ between DOCs measured at a soil depth of $10 \mathrm{~cm}$. *Total $\mathbf{N}$ Content $\mathbf{w t} \%$ and *N:P were found to be significantly different between the DOCs (1-way ANOVA).

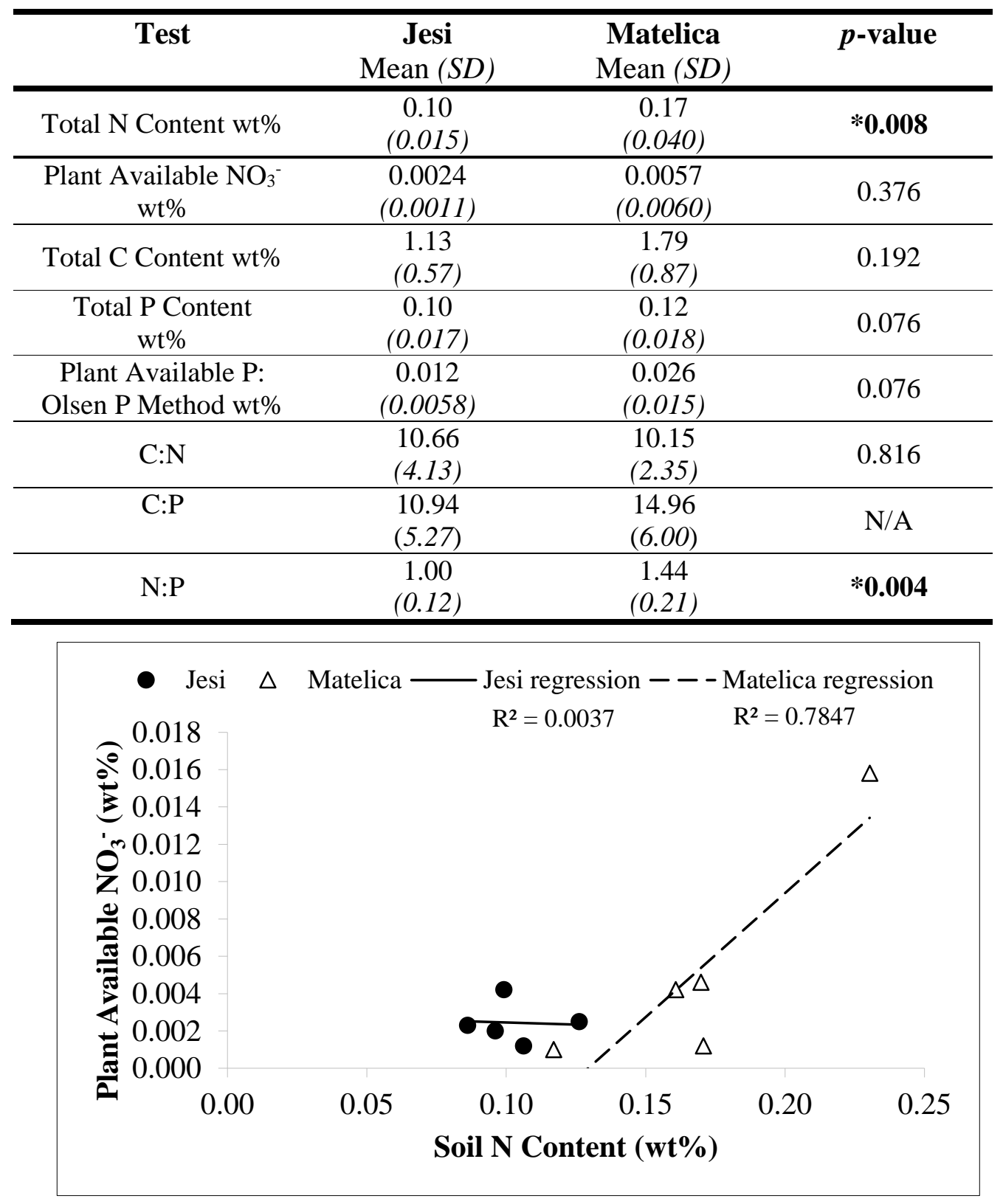

Figure 6: Plant available $\mathrm{NO}_{3}{ }^{-}$is plotted against soil N. Jesi shows a largely invariant trend, whereas Matelica is depicted with a positive slope. Lines fitted by linear regression. 


\section{Total C Content wt\%}

While mean soil total $\mathrm{C}$ content are not significantly different, Matelica soils have a higher mean value at $1.79 \pm 0.87 \mathrm{wt} \%$ compared to Jesi at $1.13 \pm 0.57 \mathrm{wt} \%$ (Table 4). Soil total C contents correlates positively with organic matter in both DOCs (Fig. 7B). Refer to Appendices

$\mathbf{L}$ and $\mathbf{M}$ for a complete list of soil $\mathbf{C}$ concentrations for Jesi and Matelica. 

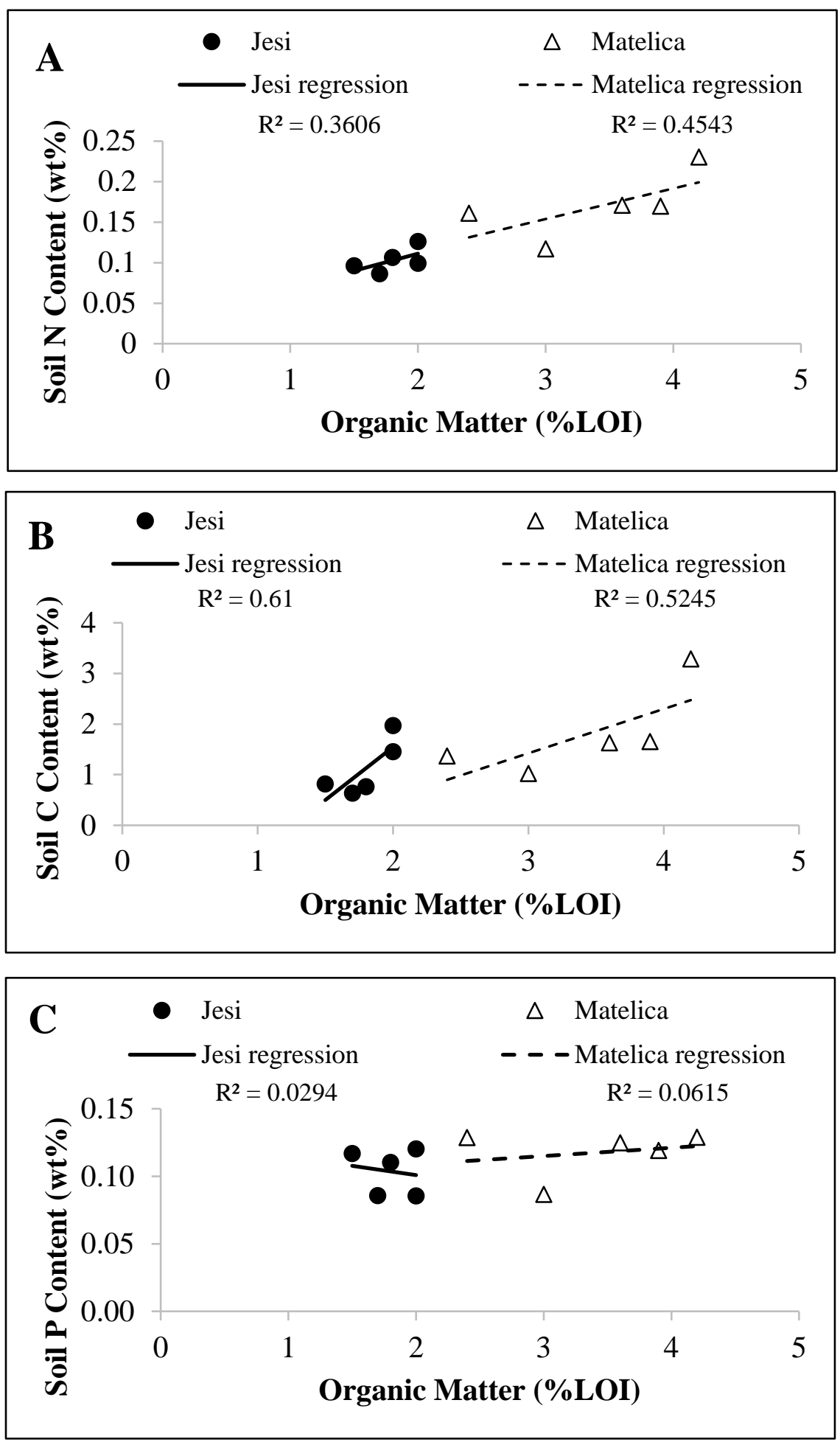

Figure 7: Soil total $\mathrm{N}$ content $(\mathbf{A}), \mathrm{C}$ content $(\mathbf{B})$, and $\mathrm{P}$ content (C) in relationship to soil organic matter. All show positive correlations except for Jesi soil P vs. organic matter, which is slightly negative. Lines are fitted by linear regression. 


\section{Total P Content wt\% and Plant Available P wt\%}

Mean soil total P content and plant available P were not statistically different $(p>0.05)$ between DOCs with Jesi total P content at $0.10 \pm 0.017 \mathrm{wt} \%$ and plant available $\mathrm{P}$ at $0.012 \pm 0.0058 \mathrm{wt} \%$, and Matelica total P content at $0.12 \pm 0.018 \mathrm{wt} \%$ and plant available $\mathrm{P}$ at $0.026 \pm 0.015 \mathrm{wt} \%$ (Table 4). Thus, Matelica has slightly higher plant available P in soil in comparison to Jesi. Moreover, soil total P contents correlated positively with organic matter in Matelica ( $\mathrm{R}^{2}$ 0.0615), but shows a weaker correlation in Jesi ( $\mathrm{R}^{2}$ 0.0294) (Fig. 7C). Both DOCs exhibited a positive relationship between plant available $\mathrm{P}$ and soil $\mathrm{P}$ content as depicted in figure 8. Refer to Appendices $\mathbf{L}$ and $\mathbf{M}$ for a complete list of soil $\mathbf{P}$ concentrations for both Jesi and Matelica and Appendix $\mathbf{N}$ for a complete list of soil plant available $\mathrm{P}$ at $10 \mathrm{~cm}$ in depth.

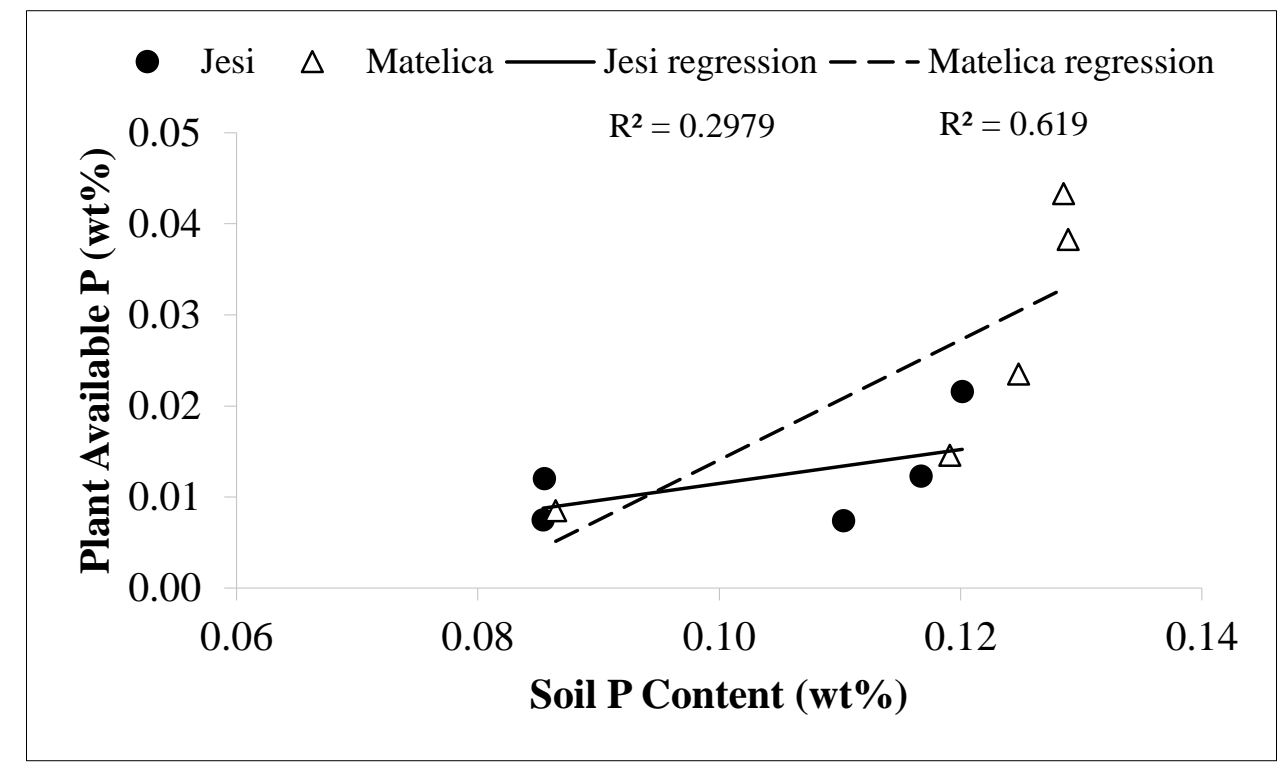

Figure 8: The relationship between plant available $\mathrm{P}$ and total $\mathrm{P}$ in soils of the two DOCs. Matelica exhibited a more positive correlation with a $\mathrm{R}^{2}$ value of 0.619 compared to Jesi at 0.298 . Lines fitted by linear regression. 


\section{Soil: Elements $N, C$, and $P$}

Macronutrient elements N, C, and P were plotted against one another in figure 9 for each DOC. Figure 9A shows a positive correlation seen in both DOCs; as soil C concentrations increase, soil N concentrations also increase. Figure 9B shows a positive correlation seen in both DOCs; as soil C concentrations increase, soil $\mathrm{P}$ concentrations also increase. Figure 9C shows a positive correlation seen in both DOCs; as soil $\mathrm{N}$ concentrations increase, soil $\mathrm{P}$ concentrations also increase.

Elements N, C, and P were also noted to be strongly related to organic content (Fig. 7) and can be further noted in figure 9 with Matelica continuously showing higher concentrations in $\mathrm{N}, \mathrm{C}$, and $\mathrm{P}$ in comparison to Jesi. Furthermore, N:P is significantly different in the two DOCs $(p=0.004)($ Table 4). 

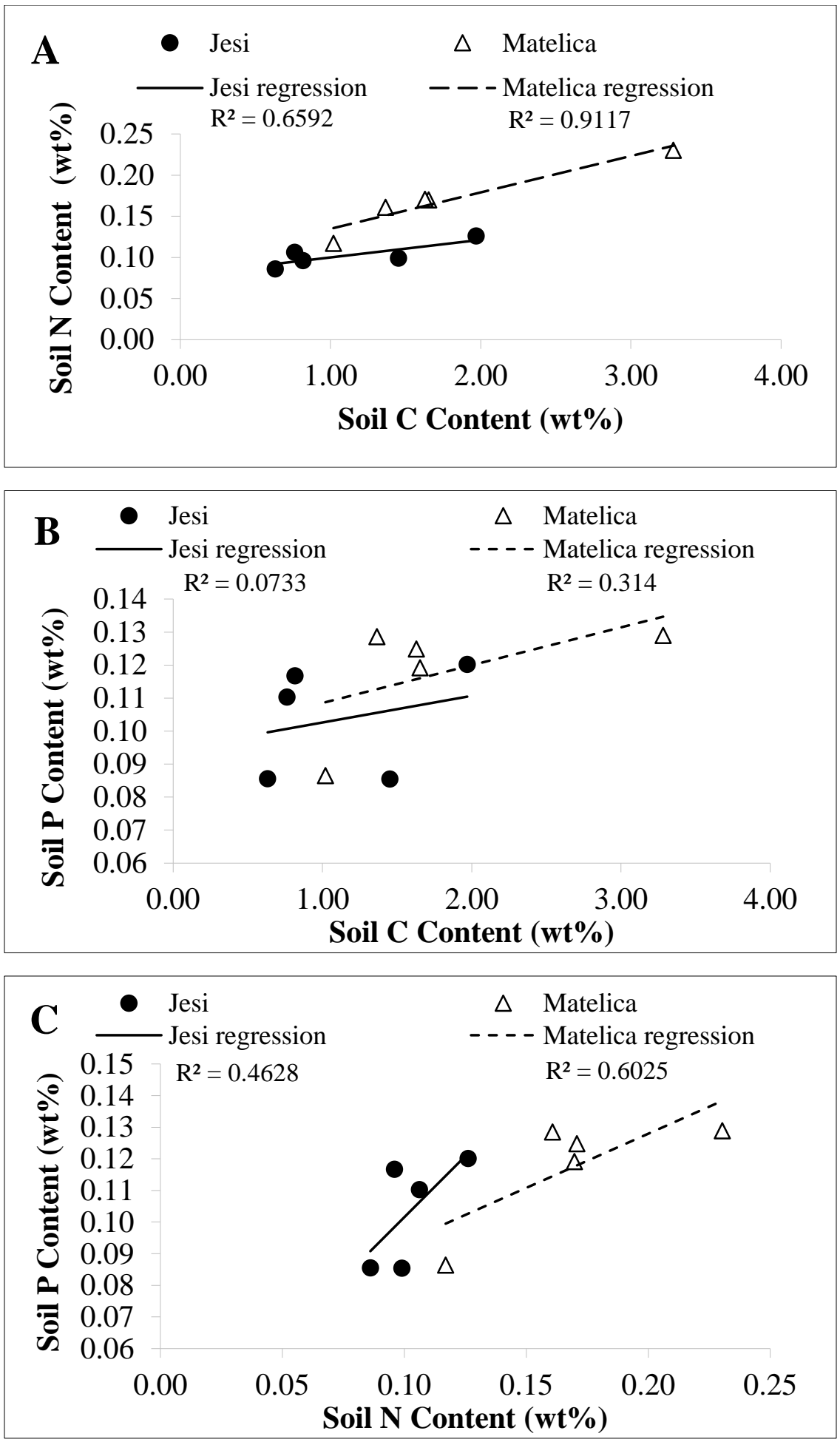

Figure 9: Soil elements $\mathrm{C}, \mathrm{N}$, and $\mathrm{P}$ depict positive correlations when plotted against one another for all 5 soil profiles in each DOC (A) N vs. C (B) P vs. C (C) P vs. N. Lines fitted by linear regression. 


\section{Grapevine Stems}

\section{Total N, C, and P Content wt\%}

While mean total grapevine stem $\mathrm{N}$ contents were not statistically different between DOCs $(p>0.05)$ (Table 5), a higher concentration was noted in Matelica $( \pm 0.086)$ than Jesi $( \pm 0.039)$. Mean total C content between DOCs were very similar with Jesi at $45.12 \pm 0.50 \mathrm{wt} \%$ and Matelica at 45.34 $\pm 0.34 \mathrm{wt} \%$ (Table 5). Mean total $\mathrm{P}$ content was statistically different $(p=$ 0.016) with higher concentrations in Jesi at $0.24 \pm 0.046 \mathrm{wt} \%$ compared to Matelica at $0.17 \pm$ 0.032 wt\% (Table 5). Refer to Appendix $\mathbf{O}$ for a complete list of grapevine stem N, C, and P concentrations.

Table 5: Grapevine stem macronutrients $\mathrm{N}, \mathrm{C}$, and $\mathrm{P}$ concentrations in wt $\%$ as well as elemental ratios. *Total $\mathbf{P}$ Content, ${ }^{*} \mathbf{N}: \mathbf{P}$, and ${ }^{*} \mathbf{C}: \mathbf{P}$ are statistically different between DOCs (1-way ANOVA).

\begin{tabular}{cccc}
\hline Test & $\begin{array}{c}\text { Jesi } \\
\text { Mean }(S D)\end{array}$ & $\begin{array}{c}\text { Matelica } \\
\text { Mean }(S D)\end{array}$ & $\boldsymbol{p}$-value \\
\hline Total N Content & $\begin{array}{c}0.43 \\
(0.039)\end{array}$ & $\begin{array}{c}0.49 \\
(0.086)\end{array}$ & \multirow{2}{*}{0.140} \\
wt\% & $\begin{array}{c}45.12 \\
(0.50)\end{array}$ & $\begin{array}{c}45.34 \\
(0.34)\end{array}$ & \multirow{2}{*}{0.438} \\
\hline Total C Content & $\begin{array}{c}0.24 \\
\text { wt\% }\end{array}$ & $\begin{array}{c}0.17 \\
(0.032)\end{array}$ & \multirow{2}{*}{$* \mathbf{0 . 0 1 6}$} \\
\hline Total P Content & $(0.046)$ & $\begin{array}{c}94.14 \\
(16.93)\end{array}$ & \multirow{2}{*}{0.178} \\
wt\% & $\begin{array}{c}106.82 \\
(9.10)\end{array}$ & $\begin{array}{c}278.14 \\
(56.18)\end{array}$ & $* \mathbf{0 . 0 2 1}$ \\
\hline C:N & $\begin{array}{c}190.59 \\
(38.30)\end{array}$ & $\begin{array}{c}3.06 \\
(0.99)\end{array}$ & \multirow{2}{*}{$\mathbf{0 . 0 3 3}$} \\
\hline C:P & $\begin{array}{c}1.80 \\
(0.45)\end{array}$ & &
\end{tabular}

\section{Grapevine Stems: Elements $N, C$, and, and $P$}

Macronutrient N, C, and P concentrations show weak negative relationships in stem contents (Fig. 10). Grapevine stem C:P ratios $(p=0.021)$ and $\mathrm{N}: \mathrm{P}$ ratios $(p=0.033)$ were determined to be statistically different between DOCs (Table 5). 

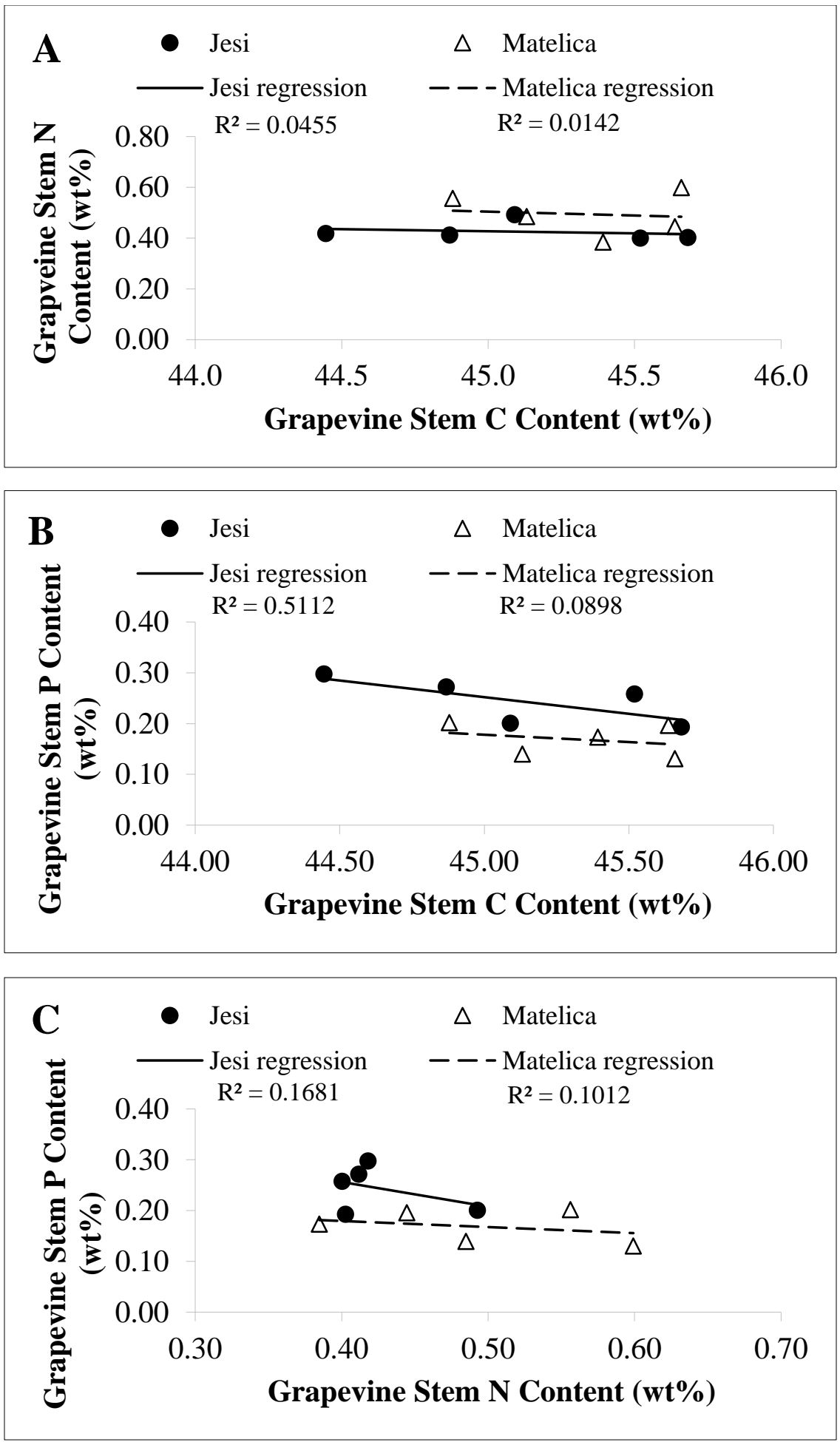

Figure 10: The relationship between grapevine stem elements $\mathrm{C}, \mathrm{N}$, and $\mathrm{P}$ across both DOC (A) N vs. C (B) *P vs. $\mathbf{C}(\mathbf{C}) * \mathbf{P}$ vs. $\mathbf{N}$ (1-way ANOVA). Lines fitted by linear regression. 


\section{Soil-Grapevine Stem Comparisons}

\section{Soil-Grapevine Stem N Interactions}

A positive correlation between soil and grapevine stem $\mathrm{N}$ concentrations for both DOCs was determined (Fig. 11). As soil $\mathrm{N}$ content increased, grapevine stem $\mathrm{N}$ content increased with a much stronger positive relationship in Matelica $\left(R^{2}\right.$ value of 0.6917$)$ in comparison to Jesi $\left(R^{2}\right.$ value of 0.0004) (Fig. 11A). There is also a positive correlation between soil plant available $\mathrm{NO}_{3}{ }^{-}$and grapevine stem $\mathrm{N}$ content in both DOCs (Fig. 11B). Again, Matelica soil profile 4 has a plant available $\mathrm{NO}_{3}{ }^{-}$concentration of $0.01580 \mathrm{wt} \%$, which is higher than mean Matelica plant available $\mathrm{NO}_{3}{ }^{-}$at $0.0057 \mathrm{wt} \%$ and is somewhat skewing the data (Fig. 11B). With Matelica soil profile 4 aside, plant available $\mathrm{NO}_{3}{ }^{-}$and grapevine stem $\mathrm{N}$ concentrations between DOCs would be more similar. 

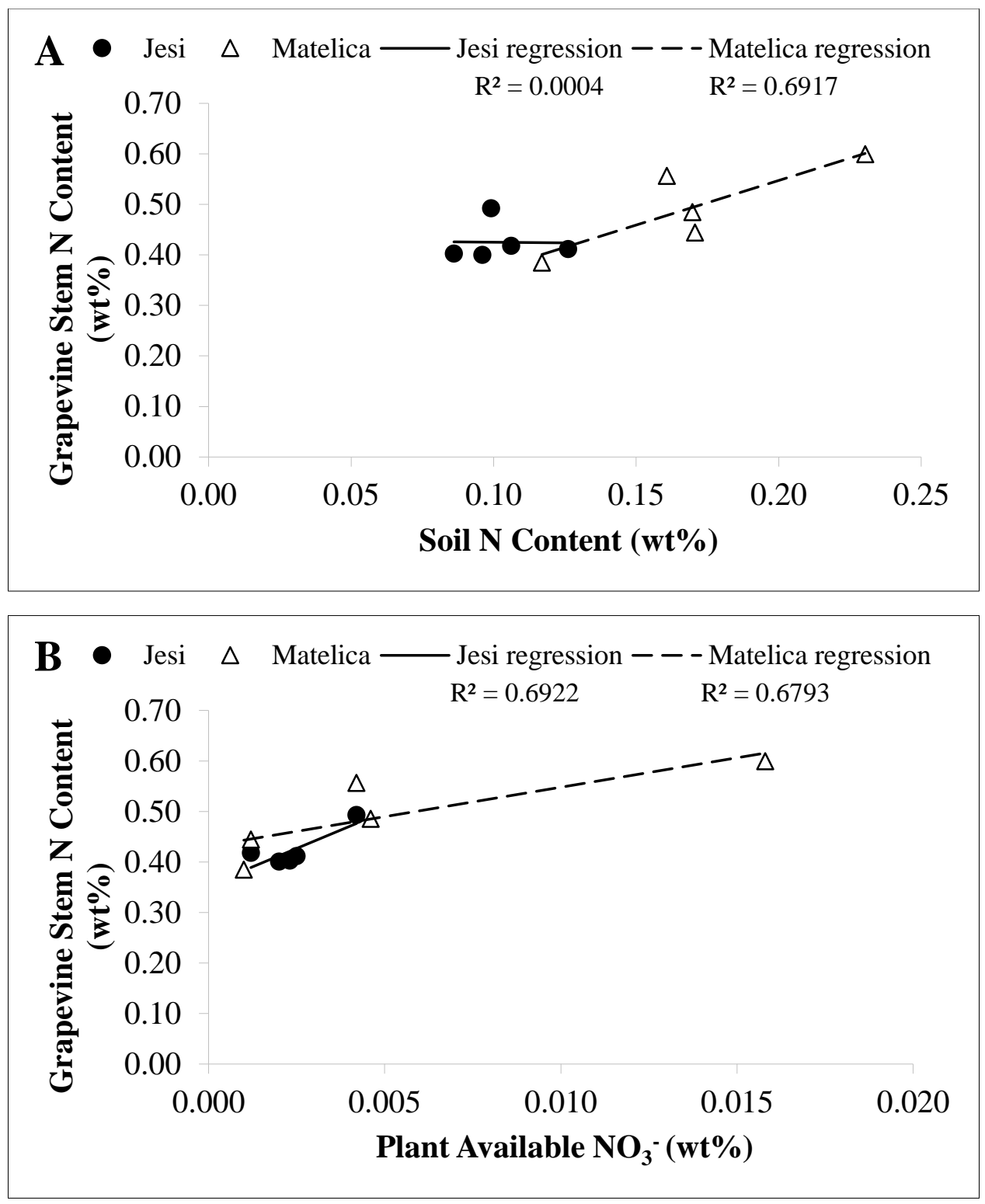

Figure 11: The relationship between grapevine stem $\mathrm{N}$ concentrations and soil $\mathrm{N}$ and soil plant available $\mathrm{NO}_{3}^{-}$. (A) There is a positive relationship between grapevine $\mathrm{N}$ and soil $\mathrm{N}$ in Matelica but no clear relationship in Jesi. (B) As soil plant available $\mathrm{NO}_{3}{ }^{-}$increases, grapevine stem $\mathrm{N}$ concentrations also increase for both Jesi and Matelica. Lines fitted by linear regression. 


\section{Soil-Grapevine Stem P Interactions}

Soil P and grapevine stem P concentrations depict variable correlations between DOCs

(Fig. 12A). Jesi depicts a positive correlation, as soil $\mathrm{P}$ concentration increases, grapevine stem $\mathrm{P}$ concentration increases (Fig. 12A). However, Matelica plant available P appears to largely unaffected with increasing soil $\mathrm{P}$ concentrations (Fig. 12A). Moreover, a positive correlation was observed between soil plant available P and grapevine stem P concentrations in both DOCs (Fig. 12B). It is important to note that while Jesi has decreased plant available $P$ concentrations, grapevine $\mathrm{P}$ concentrations are higher.

A correlation in soil \% $\mathrm{MgO}$ and grapevine stem P content was further noted, specifically in Jesi (Fig. 13). In Jesi, as soil \% $\mathrm{MgO}$ increases, grapevine stem P concentrations increase, whereas Matelica depicts a weak to negative correlation due to lack of $\% \mathrm{MgO}$ variability (Fig. 13). 

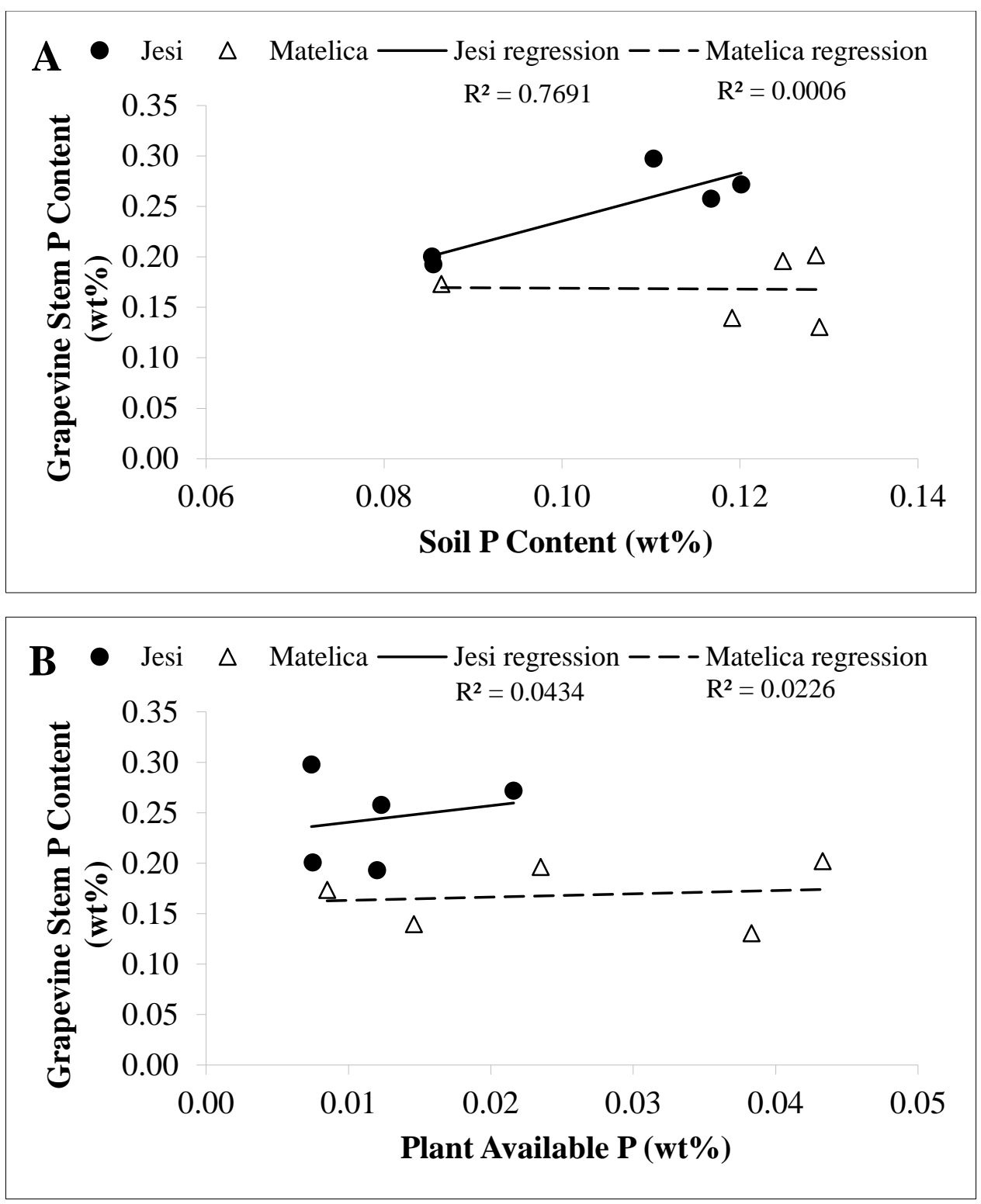

Figure 12: Soil $\mathrm{P}$ and plant available $\mathrm{P}$ are plotted against grapevine stem $\mathrm{P}$ concentrations to graphically depict soil-grapevine stem interactions. (A) As soil P content increase, Jesi grapevine stem N content increases, while Matelica expresses a weaker correlation (B) As plant available $\mathrm{P}$ increases, grapevine stem $\mathrm{P}$ increases slightly for both Jesi and Matelica. Lines fitted by linear regression. 


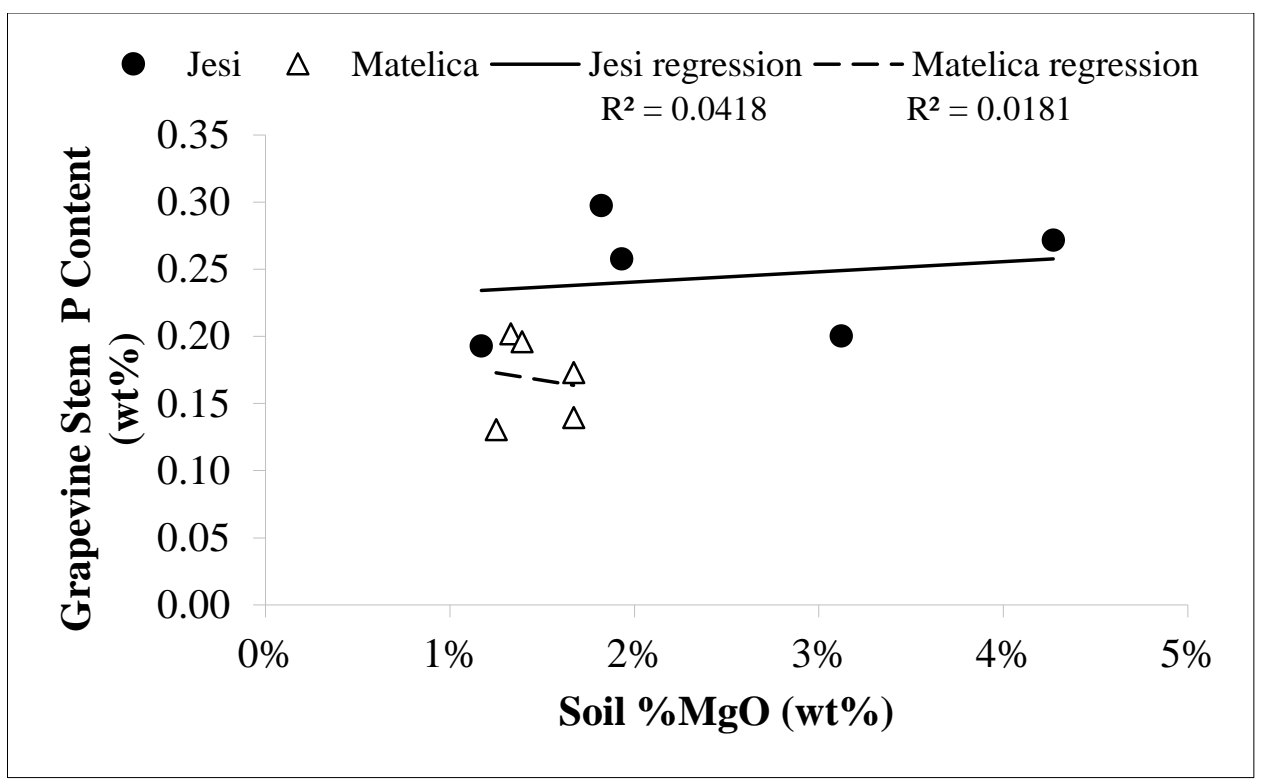

Figure 13: Graph depicts the correlation between grapevine stem $P$ content in relation to soil $\% \mathrm{MgO}$. Jesi depicts a positive correlation between $\% \mathrm{MgO}$ and grapevine stem $\mathrm{P}$. Matelica, conversely, shows a more negative trend. Lines fitted by linear regression.

\section{Soil-Grapevine Stem N Isotopes}

Grapevine stems were found to be more depleted in $15 \mathrm{~N}$ (more negative $\delta^{15} \mathrm{~N}$ values) in comparison to soil (soil depth $10 \mathrm{~cm}$ ), which were found to be more enriched in ${ }^{15} \mathrm{~N}$ (more positive $\delta^{15} \mathrm{~N}$ values) (Fig. 14). This variation in $\delta^{15} \mathrm{~N}$ values between soil and grapevine stems relates to differences in $\mathrm{N}$ transformation processes occurring. Matelica soil samples were analyzed as slightly more enriched in $\delta^{15} \mathrm{~N}(6.30 \pm 1.04 \%$ o compared to Jesi, which were slightly less enriched (5.23 $\pm 0.40 \%$ ). Moreover, grapevine stems in Matelica were more enriched in $\delta^{15} \mathrm{~N}$ $(2.61 \pm 2.46 \%$ ) compared to Jesi $(-0.17 \pm 1.06 \%$ ). 

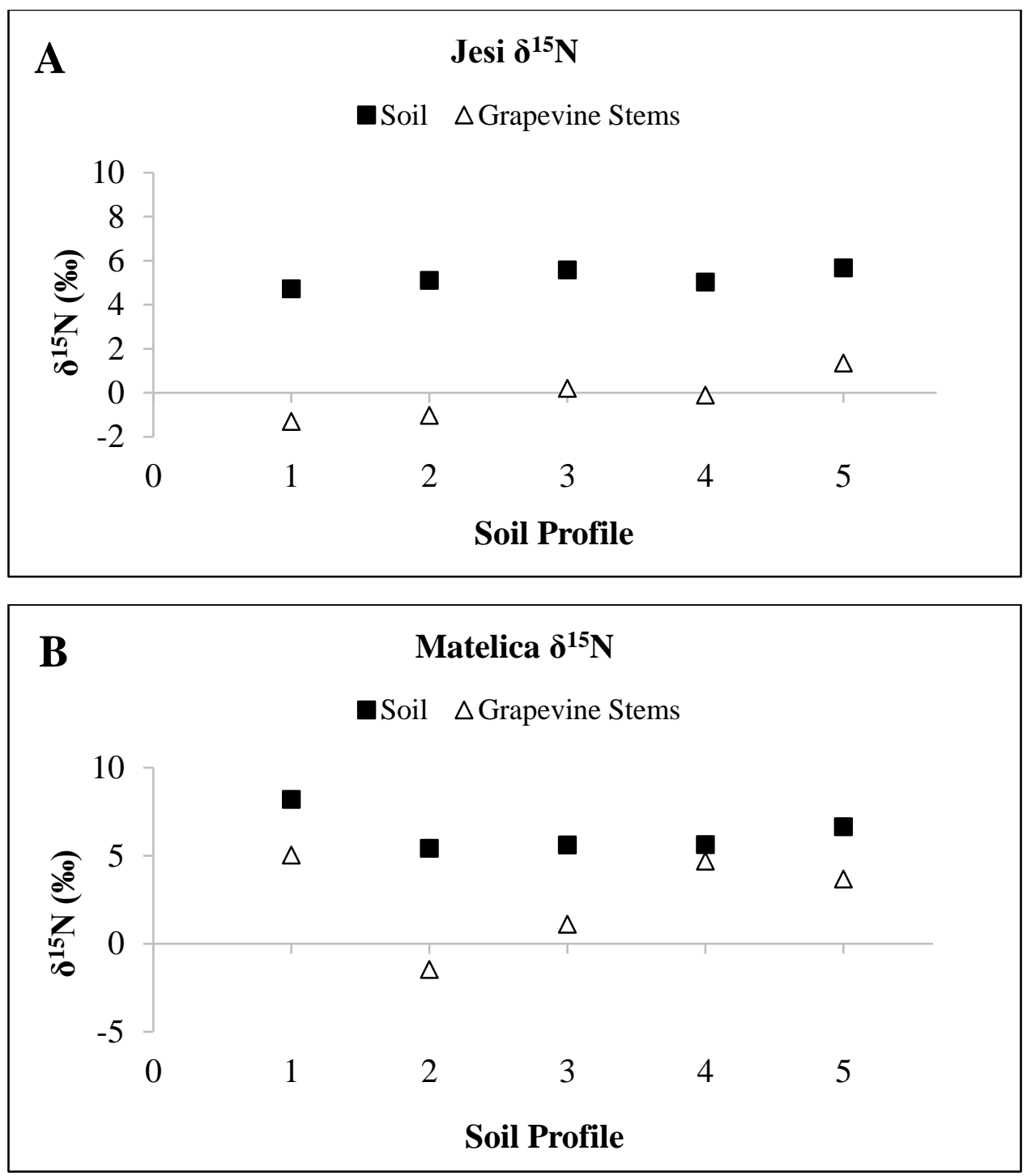

Figure 14: $\delta^{15} \mathrm{~N}$ values derived from analysis of $10 \mathrm{~cm}$ soil and grapevine stem samples from the two DOCs. Jesi (A) shows lower $\delta^{15} \mathrm{~N}$ than Matelica (B) for both soil, and grapevine stem samples.

\section{Soil-Grapevine Stem Nitrogen Turnover}

Plant $\mathrm{N}$ cycling throughout the growing season was modeled by calculating the $\mathrm{N}$ turnover $(\tau)$ occurring within the plant using individual soil and grapevine stem $\mathrm{N}$ isotopic ratios (source sink relationship). The number of $\mathrm{N}$ turnovers occurring within the plant throughout the growing season were interpreted to be significantly different between DOCs $(p=0.032)$ with Jesi having an higher $\mathrm{N}$ turnover at $1.409 \pm 0.003$ than Matelica at $0.791 \pm 0.6$ (Table 6). Matelica 
soil profiles 2 and 3 have the highest $\mathrm{N}$ turnover values in comparison to its other soil profiles

(Table 6). These two soil profiles (Matelica soil profiles 2 and 3) are also the soil profiles with the most depleted $\delta^{15} \mathrm{~N}$ values in the DOC of Matelica (Fig. 14); thus, showing a similar relationship with Jesi $\mathrm{N}$ turnover values.

Table 6: Characteristic rate constants $(\lambda)$ were determined through individual exponential regressions modeled throughout the growing season and were used to calculate the half-life $\left(\mathrm{t}_{1 / 2}\right)$. The half-life was then used to calculate the $\mathrm{N}$ turnover $(\tau)$ occurring within the grapevine.

\begin{tabular}{|c|c|c|c|c|c|}
\hline & $\mathbf{N}_{(t)}$ & $\mathbf{N}_{(\mathbf{o})}$ & $\lambda$ & $\mathbf{t}_{1 / 2}$ & $\tau$ \\
\hline & $\begin{array}{l}\text { Grapevine Stem } \\
\text { Isotopic Ratio }\end{array}$ & $\begin{array}{c}\text { Soil Isotopic } \\
\text { Ratio }\end{array}$ & $\begin{array}{c}\text { Characteristic } \\
\text { Rate } \\
\text { Constants }\end{array}$ & $\begin{array}{c}\text { Half-Life } \\
\text { (hours) }\end{array}$ & N Turnover \\
\hline \multicolumn{6}{|l|}{ Jesi } \\
\hline 1 & 0.367 & 0.369 & $1.72 \mathrm{E}-06$ & 162.58 & 1.412 \\
\hline 2 & 0.367 & 0.370 & $1.75 \mathrm{E}-06$ & 159.79 & 1.410 \\
\hline 3 & 0.368 & 0.370 & $1.54 \mathrm{E}-06$ & 181.58 & 1.407 \\
\hline 4 & 0.368 & 0.370 & $1.47 \mathrm{E}-06$ & 190.23 & 1.405 \\
\hline 5 & 0.368 & 0.370 & $1.23 \mathrm{E}-06$ & 227.35 & 1.411 \\
\hline \multicolumn{6}{|c|}{ Matelica } \\
\hline 1 & 0.370 & 0.371 & $9.00 \mathrm{E}-07$ & 84.46 & 0.381 \\
\hline 2 & 0.367 & 0.370 & $1.97 \mathrm{E}-06$ & 141.95 & 1.408 \\
\hline 3 & 0.368 & 0.370 & $1.29 \mathrm{E}-06$ & 216.77 & 1.404 \\
\hline 4 & 0.369 & 0.370 & $2.70 \mathrm{E}-07$ & 281.53 & 0.382 \\
\hline 5 & 0.369 & 0.370 & $8.50 \mathrm{E}-07$ & 89.43 & 0.381 \\
\hline
\end{tabular}




\section{DISCUSSION}

Understanding how soil plays a potential role in noted Verdicchio wine character between the DOCs of Jesi and Matelica was conducted through characterizing and interpreting physical, chemical, and biological variations in both soil and grapevine stem samples.

\section{Soil pH, Texture, Organic Matter, CEC, and Base Saturation}

While there was little variation in soil pH between Jesi (8.36) and Matelica (8.26), both DOCs were tested as being more basic than recommended within a vineyard setting of 5.5-7.5 (White, 2009). Soils more basic in nature could result in plant nutrient deficiencies, particularly in elements $\mathrm{P}, \mathrm{K}, \mathrm{Mg}, \mathrm{Fe}, \mathrm{Zn}$, and $\mathrm{Cu}$ (Keller, 2010). Macronutrient elements $\mathrm{P}, \mathrm{K}$, and $\mathrm{Mg}$ are recommended to be greater than $1 \%$, whereas micronutrient elements $\mathrm{Fe}, \mathrm{Zn}$, and $\mathrm{Cu}$ are recommend to be around 1,000 ppm or less depending on the nutrient $(1 \%=10,000 \mathrm{ppm})$ (White, 2009). All soils showed sufficient elemental concentrations of nutrients $\mathrm{P}, \mathrm{K}, \mathrm{Mg}, \mathrm{Fe}$, and $\mathrm{Zn}$

(Appx. J, L, and M). Just north of the Marche region of Italy, a soils study in the Veneto region, was also determined to be basic in nature with a mean $\mathrm{pH}$ of 8.1 and characterized with abundant carbonate-rich minerals (Dal Ferro et al., 2012). Overall, because Jesi and Matelica were found to have sufficient soil nutrient concentrations, it is assumed that the basic soil $\mathrm{pH}$ had a minimum impact on important nutrient availability (Epstein and Bloom, 2005). Further investigations would be needed to understand how Verdicchio, the grape varietal, has adapted, or how rootstock selection, has been impacted by higher $\mathrm{pH}$ to associated soil-root-plant interactions.

Soil texture is important for water retention, and conversely, water drainage. Finer grained soils tend to retain water better than larger grains, which tend to promote soil drainage. While very similar, Matelica soil profiles were slightly coarser in texture with two soil profiles 
texturized as silt loam (soil profiles 4 and 5), while only one soil profile in Jesi was categorized as silt loam (soil profile 1). The remaining soil profiles in both Jesi (soil profiles 2, 3, 4, and 5) and Matelica (soil profiles 1, 2, and 3) were texturized as silt. Silt soils have low clay and a maximum of $20 \%$ sand, whereas silt loam soils have low clay content and slightly higher sand content (25-35\%); thus, slightly coarser textures. Slightly coarser soil texture in Matelica soil profiles could promote lower soil water retention, therefore, lower soil moisture in comparison to Jesi soil profiles. Soil texture, along with soil organic matter, plays an important role in CEC in terms of cation retention. Finer grained soil (increased surface area) and organic rich soils (high in organic colloids, which also have an increased surface area) have a higher net negative charge due to their surface area distribution. Organic matter concentrations between DOCs were significantly different (Fig. 3) with Matelica having almost double the organic matter at $3.4 \pm 0.72 \%$ compared to Jesi at $1.80 \pm 0.21 \%$. Cations are largely associated with plant nutrients and are positivity charged ions, thus attracted to net negative charged particles (i.e. negative soil sites). An increased net negative charge (i.e. increased finer grain sizes and organic colloids) has the potential to trap more cations, therefore retaining potential nutrients. These trapped nutrients have the possibility to become reactivated as part of the soil solution for plant nutrient uptake. Because soil texture between Jesi and Matelica soil profiles are very similar, Matelica's higher organic matter concentrations is most likely accountable for Matelica's slightly higher CEC at $41.02 \%$ in comparison to Jesi at $35.02 \%$. Base cations, cations that are trapped in CEC sites, represent quantitative concentrations of certain plant nutrient $\mathrm{Mg}, \mathrm{K}$, and $\mathrm{Ca}$. Base cations are a product of soil mineralogy and soil mineral water splitting, and thus, easily leached out and precipitated into soil solution if it were not for soil CEC (Essington, 2004). While base cations are dictated by soil mineralogy, their ability to be retained within the soil depends on CEC. Base 
cations $\% \mathrm{~K}$ and $\% \mathrm{Ca}$ did not vary significantly between DOCs, but base cation \% Mg in Jesi soil profiles (8.8\%) was over double than that of Matelica soil profiles (4.2\%), most likely a direct result of soil mineralogy. \% Mg distribution is further correlated with mineralogical and oxide concentrations as discussed below.

\section{Mineralogy, Elemental, and Oxide Concentrations}

Soil mineralogy was similar between DOCs with a few distinct and critical exceptions. Jesi showed a higher dolomite abundance in comparison to Matelica, which lacked dolomite (Table 2). Mineralogical variations in soil are largely dictated by geologic bedrock and according to Conte et al. (2006), the DOC of Matelica is more carbonate-rich in comparison to the DOC of Jesi. However, because the DOCs are large and this study's sampling sites are few, geological variation must be considered on a smaller spatial scale. For instance, selected vineyards in Jesi are located in the southern portion the DOC, dominated by pelagic limestone deposits, thus explaining higher carbonate abundances/concentrations seen in analytical tests (Conte et al., 2006). The DOCs would be better represented by gathering more sample sites throughout the entirety of the DOC.

Redirecting back to Jesi and Matelica's dolomite distribution $\left(\mathrm{CaMg}\left(\mathrm{CO}_{3}\right)_{2}\right), \mathrm{Mg}$ concentrations were found to be higher in Jesi soil profiles compared to Matelica. Higher Jesi $\mathrm{Mg}$ concentrations were determined in both base saturation $\% \mathrm{Mg}$ concentrations (above) as well as in $\mathrm{XRF} \% \mathrm{MgO}$ concentrations. Mean Jesi soil profiles were analyzed as having almost double the $\% \mathrm{MgO}$ concentrations compared to mean Matelica soil profiles (Fig. 5). As mentioned in the background section introducing grapevine macronutrients, $\mathrm{Mg}$ plays a large role in biological processes such as in chlorophyll and photosynthesis reactions (Epstein and Bloom, 2005). These higher soil Mg concentrations in Jesi could affect plant Mg concentrations. Increased plant Mg 
concentrations could have several biological impacts, such as increased enzyme activity in the photosynthetic protein rubisco (Keller, 2010).

\section{Soil Concentrations: $N, C$, and $P$}

Soil elements $\mathrm{C}, \mathrm{N}$, and $\mathrm{P}$ are dependent on soil organic matter content and are critical for many biogeochemical cycles and macronutrients for plant (Sterner and Elser, 2002; Goll, 2017). Availability of $\mathrm{N}$ and $\mathrm{P}$ from soil organic matter (decomposed detritus) is important for soil fertility. Jesi exhibited lower soil $\mathrm{N}$ content due to lower organic content, and consequently, has lower concentrations of plant available $\mathrm{N}\left(\mathrm{e} . \mathrm{g} . \mathrm{NO}_{3}{ }^{-}\right.$). Soil $\mathrm{P}$ is a combination of both inorganic (dependent on soil mineralogy and composition) and organic (dependent on organic matter and soil texture) forms (Prasad et al., 2017). Total soil P showed a positive correlation with organic content in Matelica soils, suggesting P supply from organic breakdown (Fig. 7B), although, this relationship was not demonstrated in Jesi soils. Inorganic P mineral forms were not identified via $\mathrm{XRD}$, and some accessory P-bearing minerals, such as apatite $\left(\mathrm{Ca} 5\left(\mathrm{PO}_{4}\right)_{3}(\mathrm{~F}, \mathrm{Cl}, \mathrm{OH})\right)$, may not have been detected. However, for plant function, measures of plant available $\mathrm{P}$ in soils are more useful and is clearly influenced by organic element concentrations within soil (Busman et al., 2002). Overall, it is important to note that higher soil $\mathrm{P}$ and plant available $\mathrm{P}$ concentrations in Matelica are most likely a direct result of higher soil organic content.

\section{Grapevine Stem Concentrations: N, C, and P}

While soil provides plant available nutrients, it does not guarantee the plant will be able to take up the available nutrients; therefore, plant elemental concentrations do not directly reflect soil composition (Epstein and Bloom, 2005). For example, while Matelica soil profiles had higher plant available $\mathrm{P}$, grapevine stem biomass had lower $\mathrm{P}$ concentrations than Jesi grapevine 
stems, which experienced lower soil plant available P (Fig. 12B). This could be a result of nutrient co-dependence, specifically nutrients $\mathrm{P}$ and $\mathrm{Mg}$, which are known to be affected when either nutrient becomes limited (Skinner and Matthews, 1990). Mg concentrations in grapevine leaves were observed to increase with higher P supply to roots (Skinner and Matthews, 1990), suggesting that plant Mg uptake is dependent on sufficient soil P concentrations. Severe plant Mg-deficiencies manifest in leaf chlorosis (depleted leaf chlorophyll), which has downstream affects in photosynthetic capacities as well as other metabolic processes (Skinner and Matthews, 1990; Taiz and Zeiger, 2010). According to Skinner and Matthews (1990), grapevines leaves with Mg-deficiencies were not attributed to low Mg concentrations in soil but were related to Pdeficiency. They also noted leaf photosynthesis became limited when leaf $\mathrm{Mg}$ concentrations were low (Skinner and Matthews, 1990). In this research, higher \% $\mathrm{MgO}$ concentrations in Jesi soils were correlated with higher grapevine stem P concentrations, while Matelica, which had limited soil \% MgO, had lower grapevine stem $\mathrm{P}$ concentrations (Fig. 13). This study suggests a possible correlation between grapevine $\mathrm{P}$ concentrations and soil Mg concentrations; higher soil Mg concentrations could promote increased grapevine P uptake and assimilation. Overall, increased plant $\mathrm{P}$ concentrations could have potential downstream effects on metabolic processes that involve $\mathrm{P}$, specifically photosynthesis, which is also reliant on $\mathrm{P}$ for its role in plant energy metabolism (Keller, 2010).

Grapevine $\mathrm{C}$ concentrations are very similar between DOCs reflecting the majority of a grapevine's biomass. As for $\mathrm{N}$, soil plant available $\mathrm{NO}_{3}{ }^{-}$and grapevine stem $\mathrm{N}$ concentrations expressed a positive and similar correlation. Grapevine stem $\mathrm{N}$ content was more reflective when plotted against soil plant available $\mathrm{NO}_{3}{ }^{-}$in both DOCs, which could suggest some $\mathrm{N}$ limitation 
from soil N supply. However, according to White (2009), adequate total soil N concentration are within 0.9-1.2\%, which a large majority of tested soil profiles lie within (Appx. L and M).

\section{N Isotopes and N Turnover: Interpreting Biologic Rates}

Because $\mathrm{N}$ fractionation occurs during physical or enzymatic processes (Pardo and Nadelhoffer, 2010), I speculate that $\delta^{15} \mathrm{~N}$ values would suggest biological rates dependent on the type of material (soil vs. plant).

For soil, slightly more negative $\delta^{15} \mathrm{~N}$ values in Jesi suggests a higher rate of metabolic activity, such as soil transforming $\mathrm{N}$ compounds (possibly soil $\mathrm{N}$-fixation). The soil $\mathrm{N}$-cycle is primarily mediated by microorganisms and strongly dictates plant available $\mathrm{N}$ forms (Robertson and Goffman, 2015). Nitrification tends to produces ${ }^{15} \mathrm{~N}$-depleted $\mathrm{NO}_{3}{ }^{-}$, whereas ammonification can produce variable ${ }^{15} \mathrm{~N}$ values that are similar to or slightly more negative than the premineralized organic matter (Létolle, 1980; Handley and Raven, 1992; Pardo and Nadelhoffer, 2010). Soil is an active and open system; therefore, $\delta^{15} \mathrm{~N}$ enrichments and/or depletions are dependent on soil inputs, outputs, and internal fluxes (Pardo and Nadelhoffer, 2010). Mean Matelica soil profiles were analyzed as having a higher concentration of plant available $\mathrm{NO}_{3}{ }^{-}$ $(0.00536 \pm 0.0061 \mathrm{wt} \%)$, suggesting higher nitrification in comparison to mean Jesi soil profiles at $0.00244 \pm 0.0011 \mathrm{wt} \%$. If Matelica soil profile 4 was not included, Jesi and Matelica would share very similar mean plant available $\mathrm{NO}_{3}{ }^{-}$concentrations. Moreover, soil organic matter (rich in $\mathrm{N}$ and associated with $\mathrm{NH}_{4}{ }^{+}$fractionation) was also determined to be more concentrated in Matelica with mean values almost double the concentration in mean Jesi values. It would have been expected that Matelica soil would had less enriched $\delta^{15} \mathrm{~N}$ soil values in comparison to Jesi soil. However, mean Matelica soil $\delta^{15} \mathrm{~N}$ values were more enriched at $6.30 \pm 1.04 \%$ in comparison to mean Jesi soil $\delta^{15} \mathrm{~N}$ values at $5.23 \pm 0.04 \%$, which were more depleted. Our soil 
isotopic values are therefore inconsistent with soil composition data, suggesting much more complicated biological processes. Overall, soil reflects a large $\mathrm{N}$ reservoir and is continuously active. Sampling throughout the growing season as well as measuring $\mathrm{N}$ inputs from both aboveground biomass and internal inputs would further aid in understanding the soil fractionation between Jesi and Matelica at a more detailed level (Nadelhoffer and Fry, 1994).

Plants, in comparison to soil, reflect a lower magnitude reservoir of $\mathrm{N}$ and, instead, exhibit a more rapid turnover due to biosynthesis and assimilation of $\mathrm{N}$ (Nadelhoffer and Fry, 1994). Plant foliar $\delta^{15} \mathrm{~N}$ values tend to be depleted in comparison to soil $\delta^{15} \mathrm{~N}$ values likely due to a combination of $\mathrm{N}$-source isotopic composition and turnover of $\mathrm{N}$ inside the leaf from metabolic activity (Nadelhoffer and Fry, 1994; Höberg, 1997; Pardo et al., 2007; Pardo and Nadelhoffer, 2010). This study instead focuses on woody tissue and speculated $\mathrm{N}$ fraction to correlate with rates in amino acid synthesis (primary source of $\mathrm{N}$ in plant tissues) (Wermelinger, 1991; Nadelhoffer and Fry, 1994). Plant tissues exhibit routine enzymatic synthesis and turnover, which are then primarily stored within the woody perianal tissue (Wermelinger, 1991). Jesi grapevine stems were found to have a more depleted $\delta^{15} \mathrm{~N}$ value at $-0.17 \pm 1.06 \%$, compared to Matelica grapevine stems at $2.61 \pm 2.46 \%$ (Fig. 14). While woody tissues (grapevine stems) do not photosynthesize, they do rely on imported photosynthate and act as storage sites for amino acids and proteins (Keller, 2010). I, therefore, speculate that plant $\mathrm{N}$ isotopes in the grapevine stems could reflect rates of amino acid synthesis through their role as storage sites for amino acids. In other words, increased $\mathrm{N}$ fraction (more negative $\delta^{15} \mathrm{~N}$ values) in grapevine stems would reflect higher amino acid storage, therefore, suggesting a higher rate of amino acid synthesis occurring within that plant system. Phenological stages must be considered when discussing variations in potential amino acid storage within woody tissue (grapevine stems), as 
storage concentrations can be strongly dictated depending on the season. Jesi and Matelica grapevine stems were sampled during the veraison stage.

Durante et al. (2016), analyzed light elements in soil, grapevine stems, and grape juice in order to establish their efficiency as a tracer for wine provenance, or geographical origin. $\mathrm{N}$ isotopic values measured in their study for both soil and grapevine stems are similar to the values in this study; soil samples were notably more enriched in $\delta^{15} \mathrm{~N}$, ranging from $+9 \%$ to $+3 \%$, in comparison to grapevine stems samples, ranging from $+4 \%$ o to $-4 \%$ (Durante et al., 2016). They speculated that bulk soil samples were enriched in $\delta^{15} \mathrm{~N}$ compared to grapevine stems due to the higher biological demands required during $\mathrm{N}$ uptake and assimilation resulting in increased isotope fractionation (Durant et al., 2016).

In order to better comprehend N's source (soil) - sink (grapevine stem) relationship throughout the growing season, the number of $\mathrm{N}$ turnovers (or amino acid turnovers) within the plants were simulated using a stable isotope-based progress-variable model (Cerling et al., 2007). This model took into account the critical growing season between bloom and harvest and used known amino acid turnover rates that were sourced from Finlay et al. (1988). Jesi was found to have a higher $\mathrm{N}$ turnover throughout the growing season at $1.41 \pm 0.0030$, compared to Matelica at $0.791 \pm 0.56$. This model further highlights possible variations in amino acid storage within the grapevine stem as well as possible correlating assumptions in amino acid synthesis. Overall, between $\mathrm{N}$ isotope and $\mathrm{N}$ turnover interpretations, I speculate that Jesi grapevine stems have a notably higher amino acid synthesis in relation to Matelica grapevine stems suggesting increased biological/metabolic activity. 


\section{Verdicchio: Understanding the Wine Flavor Variation}

Tannins, a phenolic compound, are known to impact wine structure, quality, aging potential, and are often associated with bitterness and astringency (Pambianchi, 2003). There are many phenolic compounds and they all have the potential to influence wine flavor profiles in myriad ways (Donovan et al., 1998; Keller, 2010). Studies have observed calcareous vineyard soils to produce grapes with enhanced smoothness and mild wine tannin character, whereas siliceous vineyard soils have been linked to more robust grapes with stronger wine tannin character (Conte et al., 2006; Burns, 2012). Verdicchio from Jesi was characterized as smooth, whereas Verdicchio from Matelica was characterized as strong and bold (Bastianich and Lynch, 2002; Conte et al., 2006), both correlating with respective variations in soil composition. While both DOCs were determined to be calcareous, Jesi soils were determined to be more carbonaterich due to more dolomite and calcite concentrations, whereas Matelica soils had slightly less calcite and no dolomite, but had higher siliceous concentrations compared to Jesi. How might these soil variations impact wine tannin character?

Higher soil Mg concentrations in Jesi could play a role in increased Mg plant uptake. This increased $\mathrm{Mg}$ uptake could promote chlorophyll production/activity, due to its leading role involved in the molecule and photosynthetic enzyme activation (Keller, 2010). Jesi grapevine stems were also determined to have higher $\mathrm{P}$ concentrations compared to Matelica, again possibly impacting biologic functions, most specifically, photosynthesis. As Jesi grapevine stems were interpreted to have a higher rate of amino acid synthesis and measured $\mathrm{P}$ concentrations, it could, in turn, reflect Jesi having a higher rate of chlorophyll synthesis as well as promote photosynthetic capacities. Differences in photosynthesis could affect both sugar and metabolic pathways such as phenolic compound character, specifically tannins, which are known to 
contribute to wine flavor and wine characteristics (Donovan et al., 1998; Pambianchi, 2003). A comprehensive study by Gerendàs and Führs (2013) correlated increased \% MgO concentrations in the soil to decreased phenolic compound traits, possibly correlating to more mild wine tannin characteristics (cf. Jesi), in comparison to decreased $\% \mathrm{MgO}$ concentrations to increased phenolic compound traits, possibly correlating to wine with stronger tannin characteristics (cf. Matelica).

Overall, I hypothesize that increased soil $\mathrm{Mg}$ concentrations in Jesi, due to dolomite, could promote increased P plant uptake as well as promote chlorophyll synthesis, and therefore, affect metabolic processes associated with wine tannin character. 


\section{FUTURE WORK}

This research focused on primarily on soil-grapevine interactions, and would benefit from a more holistic approach encompassing in-depth analyses and observations on climate, slope, aspect, geomorphology, anthropogenic controls, etc., in order to better evaluate all factors that could be attributed to wine flavor variations.

While the four selected vineyards and five soil profiles in each DOC resulted in notable variations in mineralogy and nutrient parameters, the study would benefit with increased sample sites and sample replication, which would improve the statistical power of our analyses. In addition, grapevine leaves, instead of stems, would be the ideal plant tissues sample as they are the site of photosynthetic reactions, so are more metabolically active, and the synthesis of chlorophyll could be quantified. The analysis of grape juice and/or wine for tannins and other phenolic compounds, wine $\mathrm{pH}$, and wine trace elements would further aid in understanding the soil-grapevine interactions and impacts on plant nutrition on fruit yield and quality.

A more comprehensive temporal approach could also be taken analyzing the vineyard soil and grapevine (stems and leaves) throughout the phenological stages, starting from bud break to harvest, in order to more accurately understand the $\mathrm{N}$ turnover within the plant. This would result in an increased understanding of the chemical variations occurring in soil and grapevines throughout the growing season. 


\section{CONCLUSIONS}

While the DOCs of Jesi and Matelica are in close proximity, they have certain distinct soil characteristics that strongly impact potential soil-grapevine interactions. Mineralogically, Jesi was noted to be relatively abundant in dolomite $\left(\mathrm{CaMg}\left(\mathrm{CO}_{3}\right)_{2}\right)$ in comparison to Matelica, which lacked dolomite. This dolomite distribution resulted in increased soil $\mathrm{Mg}$ concentrations in

Jesi evidenced in both XRF and base saturation tests. Biological rates were evaluated through the analysis of $\mathrm{N}$ isotopes on both soil and grapevine stems. Most notably, Jesi grapevine stems were interpreted to have a higher rate of amino acid synthesis in comparison to Matelica grapevine stems. Furthermore, Jesi grapevine stems were calculated to have double the $\mathrm{N}$ turnover throughout the growing season compared to Matelica grapevine stems. Overall, I speculate that this difference in grapevine stem amino acid synthesis is attributed to soil mineralogy, specifically dolomite in Jesi soils. As a magnesium carbonate, dolomite might impact plant $\mathrm{Mg}$ availability, and possible plant $\mathrm{P}$ uptake, as Jesi grapevine stems also had higher $\mathrm{P}$ concentrations despite higher plant available $\mathrm{P}$ in Matelica soils. Elements $\mathrm{N}, \mathrm{P}$, and Mg could affect photosynthetic capacities and downstream production of secondary phenolic compounds, specifically tannins, which has a strong effect on wine flavor. The soil-grapevine interaction elucidated in this terroir study could help advance the use of natural soil additives (e.g. dolomite) to guide wine producers in achieving a desired flavor profile.

This research does not make a commentary on whether one style of Verdicchio is better than the other, it does, however, critically address how soil could affect grapevines and in turn, affect Verdicchio flavor characteristics noted in both Jesi and Matelica. 


\section{REFERENCES}

Barchi, M. R. (1991). Integration of a seismic profile with surface and subsurface geology in a cross section through the Umbria-Marche Apennines. Bollettino Della Societa Geologica Italiana, 110, 469-479.

Bastianich, J., Lynch, D. (2002). Vino Italiano: The regional wines of Italy (pp. 5-9; 239-252; 415). New York, New York: Clarkson Potter/Publishers.

Bott, T., Meyer, G. A., Young, E. B. (2008). Nutrient limitation and morphological plasticity of the carnivorous pitcher plant Sarracenia purpurea in contrasting wetland environments. New Phytologist, 180(3), 631-641.

Brundrett, M. C. (2009). Mycorrhizal associations and other means of nutrition of vascular plants: Understanding the global diversity of host plants by resolving conflicting information and developing reliable means of diagnosis. Plant Soil, 320, 37-77.

Burns S. (2012) The Importance of Soil and Geology in Tasting Terroir with a Case History from the Willamette Valley, Oregon. In: Dougherty P. (Eds.), The Geography of Wine (pp. 95-108). Springer, Dordrecht.

Busman, L., Lamb, J., Randall, G., Rehm, G., Schmitt, M. (2002). Nutrient management: The nature of phosphorus in soils. University of Minnesota-Extension, Retrieved from http://www.extension.umn.edu/agriculture/nutrient-management/phosphorus/the-nature-ofphosphorus/

Cavinato, G. P., De Celles, P. G. (1999). Extensional basins in the tectonically bimodal central Apennines fold-thrust belt, Italy: Response to corner flow above a subducting slab in retrograde motion. Geology, 27, 955-958.

Cerling, T. E., Ayliffe, L. K., Dealing, M. D., Ehleringer, J. R., Passey, B. H., Podlesak, D. W., Torregrossa, A., West, A. G. (2007). Determining biological tissue turnover using stable isotopes: The reaction progress variable. Oecologia, 151(2), 175-189.

Conte, M., Rossini, L., Tiberi, M., Montanari, A. (2006). Verdicchio dei Castelli di Jesi vs Verdicchio di Matelica: Geomorphological control of two white wines of the Marche region (northeastern Apennines, Italy). Bollettino Della Società Geologica Italiana E Del Servizio Geologico D'Italia, 6, 41-48.

Dal Ferro, N., Berti, A., Francioso, O., Ferrari, E., Matthews, G. P., Morari, F. (2012). Investigating the effects of wettability and pore size distribution on aggregate stability: the role of soil organic matter and the humic fraction. European Journal of Soil Science, 63, 152-164.

Donovan, J. L., McCauley, J. C., Nieto, N. T., Waterhouse, A. L. (1998). Effects of small-scale fining on the phenolic composition and antioxidant activity of merlot wine. In: A. L. 
Waterhouse, \& S. E. Ebeler (Eds.), Chemistry of wine flavor (pp. 142). Washington D.C.: American Chemical Society.

Durante, C., Bertacchini, L., Bontempo, L., Camin, F., Manzini, D., Lambertini, P., Marchetti, A., Paolini, M. (2016). From soil to grape and wine: Variation of light and heavy elements isotope ratios. Food Chemistry, 210, 648-659.

Ehmke, T. (2017). Mycorrhizae: Super highway to soil health. Crops \& Soils Magazine, 50(1), 8-10.

Epstein, E., Bloom, A. J. (2004). Mineral nutrition of plants: Principles and perspectives $\left(2^{\text {nd }}\right.$ ed.). Sunderland, MA: Sinauer Associates, Inc.

Essington, M. E. (2004). Soil and water chemistry: An integrative approach. Boca Raton, Florida: CRC Press LLC.

Field, C., Mooney, H. A. (1983). The photosynthesis-nitrogen relationship in wild plants. In: T. Givnish (Eds.), On the economy of plant form and function (pp. 25-55). New York:

Cambridge University Press, Cambridge.

Finlay, R. D., Ek, H., Odham, G., Söderström, B. (1988). Mycelial uptake, translocation and assimilation of nitrogen from ${ }^{15} \mathrm{~N}$-labelled ammonium by Pinus sylvestris plants infected with four different ectomycorrhizal fungi. New Phytologist, 110(1), 59-66.

Frank, K., Beegle, D., Denning, J. (1998). Phosphorus. In: NCR-13 Representatives (Eds.), Recommended Chemical Soil Test Procedures for the North central Region (pp. 6.1). Missouri Agricultural Experiment Station SB 1001.

Franzan, M. (2000). In: Nardini (Eds.), Verdicchio (pp. 1-115). Firenze.

Fraústo da Silva, J. J. R., Williams, R. J. P. (1991). The biological chemistry of the elements: The inorganic chemistry of life. Oxford: Clarendon Press.

Gerendàs, J., Führs, H. (2013). The significance of magnesium for crop quality. Plant Soil, 368, 101-123.

Gimsing (2014). Climate zones in Italy. Köppen-Geiger Classification systems using ArcGIS.

Goll, D. S. (2017). Coupled cycling of carbons, nitrogen, and phosphorus. In: R. Lal, \& B. A. Stewart (Eds.), Soil Phosphorus (pp. 43-64). Boca Raton, FL: Taylor \& Francis Group.

Gulbranson, E. L., Montañez, I. P., Tabor, N. J. (2011). A proxy for humidity and floral province from paleosols. The Journal of Geology, 119(6), 559-573.

Handley, L. L., Raven J. A. (1992). The use of natural abundance of nitrogen isotopes in plant physiology and ecology. Plant, Cell, \& Environment, 15, 965-985.

Höberg, P. (1997). ${ }^{15} \mathrm{~N}$ natural abundance in soil-plant systems. New Phytologist, 137, 179-203. 
Jenny, H. (1980). The soil resource: Origin and behavior. New York: Springer-Verlag.

Keller, M. (2010). The Science of Grapevines: Anatomy and Physiology. Burlington, MA: Elsevier Inc.

Létolle, R. (1980). Nitrogen- 15 in the natural environment. In: P. Fritz \& J. C. Fontes (Eds.), Handbook of environmental and isotope chemistry (pp. 407-433). Amsterdam: Elsevier.

Losh, J. L., Young, J. N., Morel, F. M. M. (2013). Rubisco is a small fraction of total protein in marine phytoplankton. New Phytologist, 198(1), 52-58.

McHenry, L. J. (2009). Element mobility during zeolitic and argillic alteration of volcanic ash in a closed-basin lacustrine environment: Case study Olduvai Gorge, Tanzania. Chemical Geology, 265, 540-552.

Nadelhoffer, K. J., Fry, B. (1988). Controls on natural nitrogen-15 and carbon-13 abundances in forest soil organic matter. Soil Science Society of America, 52(6), 1633-1640.

Nadelhoffer, K. J., Fry, B. (1994). Nitrogen isotope studies in forest ecosystems. In: K. Lajtha \& R. H. Michener (Eds.), Stable isotopes in ecology and environmental science (pp. 22-44). Cambridge: Blackwell.

Pambianchi, D. (2003). The phenol phenomenon. Retrieved from https://winemakermag.com/677-the-phenol-phenomenon

Pardo, L. H., Hemond, H. F., Montoya, J. P. (2007). Natural abundance ${ }^{15} \mathrm{~N}$ in soil and litter across a nitrate-output gradient in New Hampshire. For Ecological Management, 251, 217230.

Pardo, L., Nadelhoffer, K. (2010). Using nitrogen isotope ratios to assess terrestrial ecosystems at regional and global scales. In: J. W. West, G. J. Bowen, T. E. Dawson, \& K. P. Tu (Eds.), Isoscapes (pp. 221-249). Dordrecht: Springer Netherlands.

Parsons, T., Maita, C., Lalli, C. (1984). A manual of chemical and biological methods for seawater analysis. Oxford, UK: Pergamon Press.

Prasad, R., Shivay, Yashbir Singh, Majumdar, K., Prasad, S. (2017). Phosphorus management. In: R. Lal, \& B. A. Stewart (Eds.), Soil Phosphorus (pp. 81-113). Boca Raton, FL: Taylor \& Francis Group.

Reich, P. B., Oleksyn, J., Wright, I. J. (2009). Leaf phosphorus influences the photosynthesisnitrogen relation: A cross-biome analysis of 314 species. Oecologia, 160(2), 207-212.

Robertson, G. P., Groffman, P. M. (2015). Nitrogen Transformations. In: E. A. Paul (Eds.), Soil Microbiology, Ecology, and Biogeochemistry (pp. 421-446) Elsevier. 
Royden, L., Patacca, E., Scandone, P. (1987). Segmentation and configuration of subducted lithosphere in Italy: An important control on thrust-belt and foredeep-basin evolution. Geology, 15, 714-717.

Schreiner, R. P. (2016). Nutrient uptake and distribution in young pinot noir grapevines over two seasons. American Journal of Enology and Viticulture, 67(4), 436.

Seguin, G. (1986). 'Terroirs' and pedology of wine growing. Experientia, 42(8), 861-873.

Skelton, S. (2007). Viticulture. Great Britain: Stephen Skelton.

Skinner, P. W., Matthews, M. A. (1990). A novel interaction of magnesium translocation with the supply of phosphorus to roots of grapevine (Vitis vinifera L.). Plant, Cell and Environment, 13(8), 821-826.

Smeck, N. E., Runge, E. C. A., Mackintosh, E. E. (1983). Dynamics and genetic modeling of soil systems. In: L.P. Wilding, N.E. Smeck and G.F. Hall (Eds.), Developments in Soil Science (pp. 51-81) Elsevier Science \& Technology.

Sperazza, M., Moore, J. N., Hendrix, M. S. (2004). High-resolution particle size analysis of naturally occurring very fine-grained sediment through laser diffractometry. Journal of Sedimentary Research, 74(5), 736-743.

Sposito, G. (2008). The Chemistry of Soils. New York: Oxford University Press.

Stainton, M. P., Capel, M. J., Armstrong, F. A. (1974). Simple, efficient reduction column for use in the automated determination of nitrate in water. Analytical Chemistry, 46(11), 1616.

Sterner, R. W., Elser, J. J. (2002). Ecological Stoichiometry: The biology of elements form molecules to the biosphere. Princeton, NJ: Princeton Univ. Press.

Systat Software Inc., Sigmaplot v12.5. San Jose, California USA.

Taiz, L., Zeiger, E. (2010). Plant Physiology (5 ${ }^{\text {th }}$ ed.). Sunderland, Massachusetts: Sinauer.

Tarquini, S., Isola, I., Favalli, M., Mazzarini, F., Bisson, M., Pareschi, M. T., Boschi, E. (2007). TINITALY/01: A new triangular irregular network of Italy. Annals of Geophysics, 50, 407425.

Tarquini, S., Vinci, S., Favalli, M., Doumaz, F., Fornaciai, A., Nannipieri, L. (2012). Release of a 10-m-resolution DEM for the Italian territory: Comparison with global-coverage DEMs and anaglyph mode exploration via the web. Computers \& Geosciences, 38, 168-170.

UC Davis Stable Isotope Facility. Carbon $\left({ }^{13} \mathrm{C}\right)$ and nitrogen $\left({ }^{15} \mathrm{~N}\right)$ analysis of solids by EAIRMS. Retrieved from http://stableisotopefacility.ucdavis.edu/13cand15n.html 
van Leeuwen, C. (2010). Terroir: The effect of the physical environment on vine growth, grape ripening and wine sensory attributes. In: A. G. Reynolds ( $E d s$.), Managing wine quality (pp. 273-315).

Walker, A. P., Beckerman, A. P., Gu, L., Kattage, J., Cernusak, L. A., Domingues, T. F., Scales, J. C. (2014). The relationship of leaf photosynthetic traits - $\mathrm{V}_{\mathrm{cmax}}$ and $\mathrm{J}_{\max }$ - to leaf nitrogen, leaf phosphorus, and specific leaf area: A meta-analysis and modeling study. Ecology and Evolution, 4(16), 3218-3235.

Ward Laboratory. (2012). $\mathrm{NO}_{3}-\mathrm{N} / \mathrm{SO}_{4}-\mathrm{S}$ in soil: By LACHAT FIA. (Ward Laboratory Methods).

Ward Laboratory. (2014a). Exchangeable soil cations. (Ward Laboratory Methods).

Ward Laboratory. (2014b). Soil Olsen Phosphorus: Olsen sodium bicarbonate method run via lachat. (Ward Laboratory Methods).

Ward Laboratory. (2014c). Procedure for (AS-3000 robot) soil pH. (Ward Laboratory Methods).

Ward Laboratory. (2014d). Organic matter run on new robot. (Ward Laboratory Methods).

Wermelinger, B. (1991). Nitrogen dynamics in grapevine: Physiology and modeling. In: J. M. Rantz (Eds.), Proc. Int. Symp. Nitrogen in Grapes and Wine, Seattle, WA (pp. 23-31). Davis, CA: American Society of Enology and Viticulture.

White, R. E. (2009). Understanding Vineyard Soils. New York: Oxford University Press.

Wilson, J. E. (2001). Geology and Wine 4. The Origin and Odyssey of Terroir. Journal of the Geological Association of Canada, 28(3), 139-141.

Young, E. B., Tucker, R. C., Pansch, L. (2010). Alkaline phosphatase in freshwater Cladophoraepiphyte assemblages: Cell regulation in response to phosphorus supply and localization. Journal of Phycology, 46(1), 93-101. 


\section{APPENDICES}

\section{APPENDIX A: \\ Soil Profile, Sample ID, and Location}

\section{Jesi Soil Profiles $\rightarrow$}

1. Azienda Vinicola Sparapani Frati Bianchi

(Via Barchio, 1260034 Cupramontana-AN-Italia)

$J-F B-001$

$\mathrm{N} 43^{\circ} 26^{\prime} 43.9^{\prime \prime}, \mathrm{E} 13^{\circ} 05^{\prime} 36.1^{\prime \prime}$, Altitude: $218 \mathrm{~m}$

\section{Azienda Agricola Mancini Benito}

(Via S. Lucia, 760030 Modie Di Maiolati Sp.-AN-Italia)

$J-M-001$

$\mathrm{N} 43^{\circ} 29^{\prime} 24.0^{\prime \prime}, \mathrm{E} 13^{\circ} 08^{\prime} 20.0^{\prime \prime}$, Altitude: $165 \mathrm{~m}$

\section{Vignamato}

(Via Battinebbia, 460038 San Palo Di Jesi-AN-Italia)

$J-V A-001$

N $43^{\circ} 27^{\prime} 27.3 ”$, E $13^{\circ} 09^{\prime} 58.9^{\prime \prime}$, Altitude: $209 \mathrm{~m}$

\section{La Staffa (1)}

(Via Castellaretta, 19 Staffolo 60039-AN-Italia)

$J$-LS-001 (2004 - younger) - (steeper-slope, but lower in elevation)

$\mathrm{N} 43^{\circ} 26^{\prime} 07.3^{\prime \prime}, \mathrm{E} 13^{\circ} 10^{\prime} 07.7^{\prime \prime}$, Altitude: $330 \mathrm{~m}$

\section{La Staffa (2)}

(Via Castellaretta, 19 Staffolo 60039-AN-Italia)

$J$-LS-002 (1972 - older) - (slope-gentle, top of hill)

$\mathrm{N} 43^{\circ} 26^{\prime} 03.2^{\prime \prime}, \mathrm{E} 13^{\circ} 10^{\prime}$ 07.0", Altitude: $345 \mathrm{~m}$

\section{Matelica Soil Profiles $\rightarrow$}

1. Gagliardi

(Via A. Merloni, 562024 Matelica-MC-Italia)

$M-G-001$

$\mathrm{N} 43^{\circ} 16^{\prime} 21.4^{\prime \prime}, \mathrm{E} 12^{\circ} 58^{\prime} 58.5^{\prime \prime}$, Altitude: $391 \mathrm{~m}$

2. Azienda Agricola Filippo Maraviglia

(Via Pianné, 58462024 Matelica-MC-Italia)

$M-M-001$

$\mathrm{N} 43^{\circ} 15^{\prime} 39.5^{\prime \prime}, \mathrm{E} 13^{\circ} 02^{\prime}$ 09.0”, Altitude: $409 \mathrm{~m}$

\section{Belisario}

(Via A. Merloni, 1262024 Matelica-MC-Italia)

$M-B-001$ 
$\mathrm{N} 43^{\circ}$ 15'05.7’, E $12^{\circ}$ 59' 09.9', Altitude: 460m

\section{ColleStefano (1)}

(Loc. Colle Stefano n.3 62022 Castelraimondo-MC-Italia)

$M$-CS-001 (younger - at least 8 years old)

$\mathrm{N} 43^{\circ} 12^{\prime} 23.4^{\prime}$, E $13^{\circ} 01$ ' 38.6”, Altitude: $415 \mathrm{~m}$

\section{ColleStefano (2)}

(Loc. Colle Stefano n.3 62022 Castelraimondo-MC-Italia)

$M$-CS-002 (older - at least 30 years old)

$\mathrm{N} 43^{\circ} 12^{\prime}$ 22.1', E $13^{\circ} 01^{\prime} 35.5^{\prime}$, Altitude: $422 \mathrm{~m}$ 


\section{APPENDIX B:}

\section{Jesi Soil Texture Triangle}

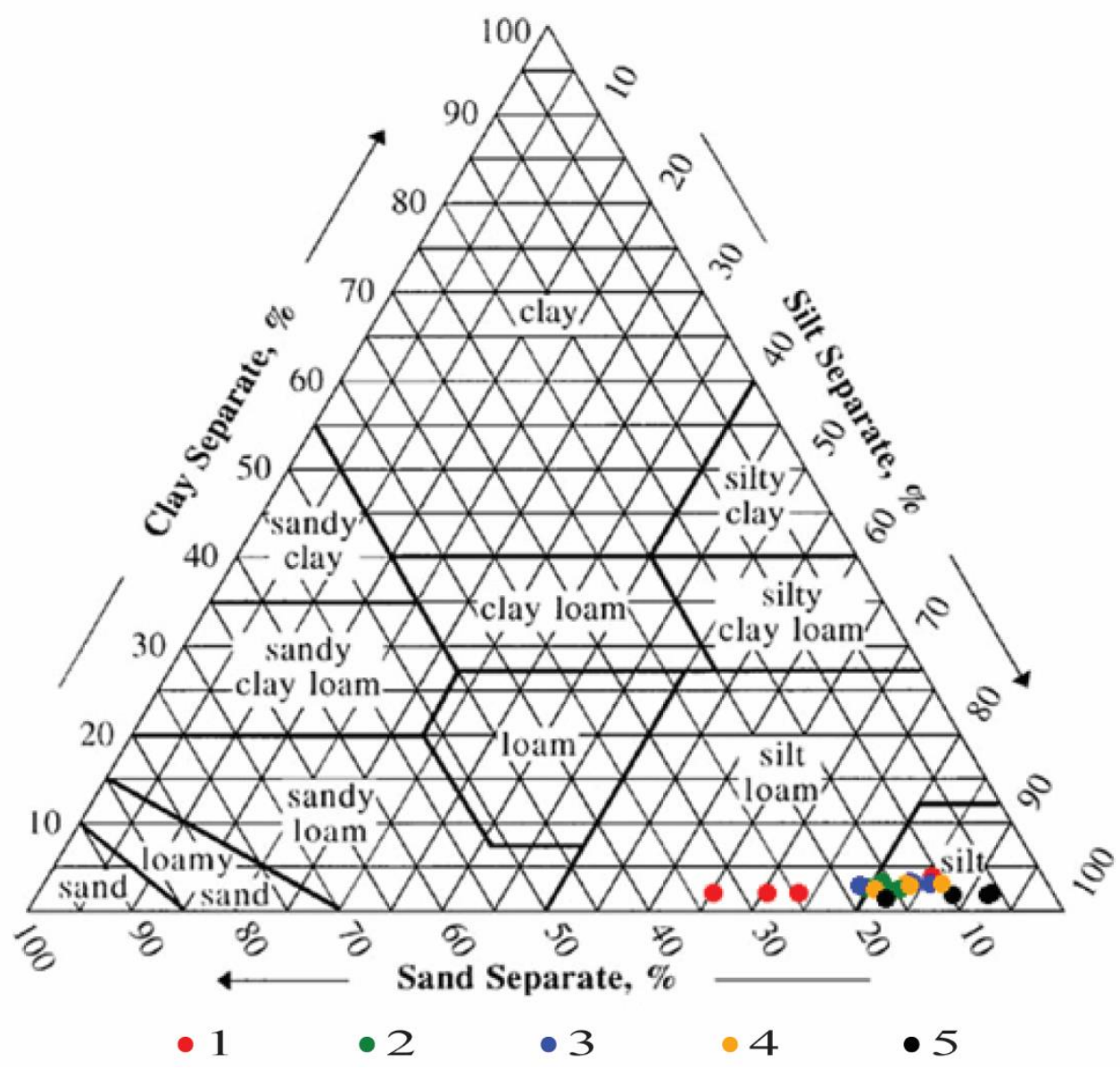

Jesi vineyard soil texture triangle representing each soil profile at each depth of $3,10,25,50 \mathrm{~cm}$ in depth. 


\section{APPENDIX C:}

\section{Matleica Soil Texture Triangle}

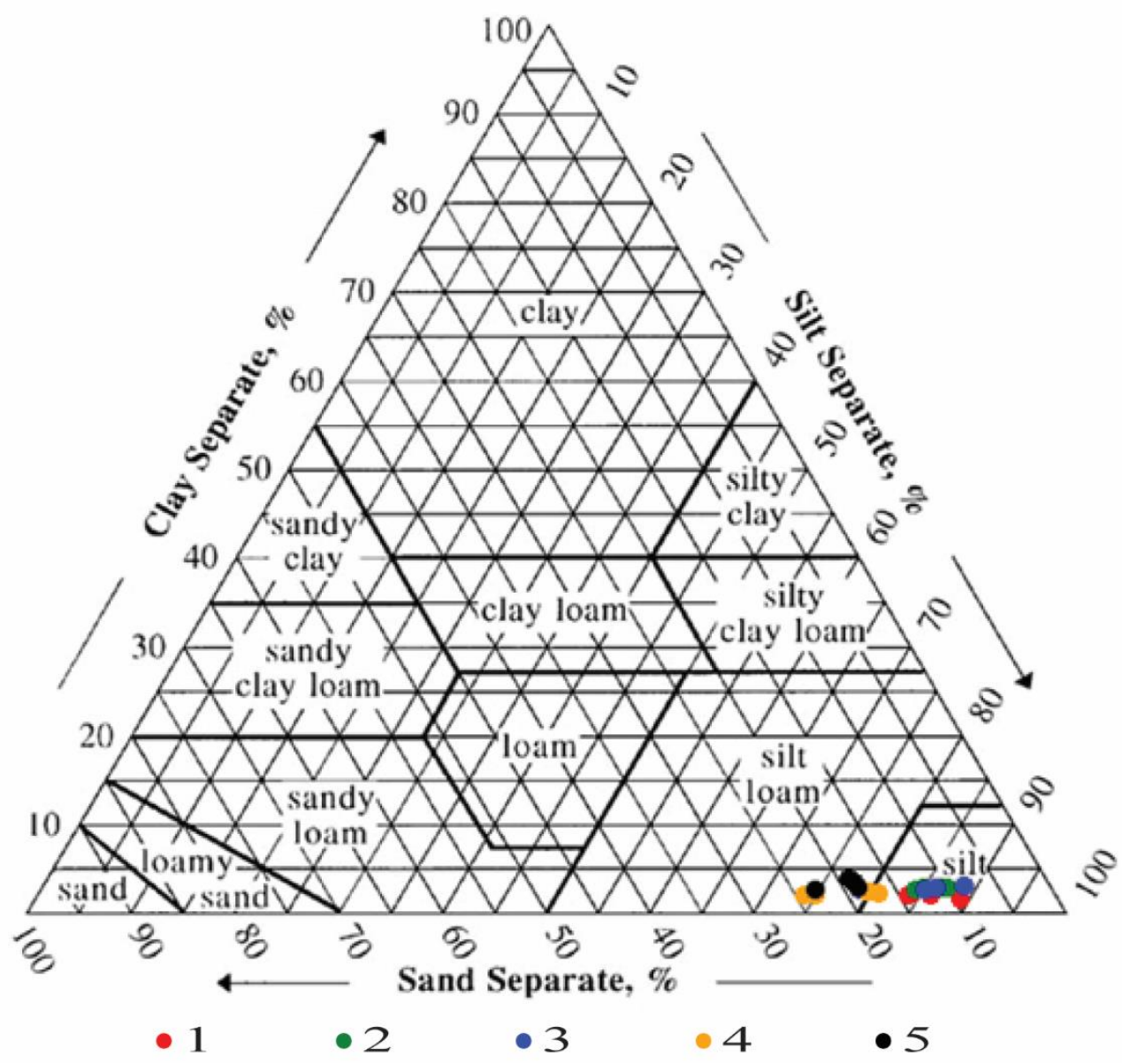

Matelica vineyard soil texture triangle representing each soil profile at each depth of $3,10,25,50 \mathrm{~cm}$ in depth. 


\section{APPENDIX D:}

Jesi and Matelica Soil pH and Organic Matter

\begin{tabular}{ccc}
\hline Soil Profile & 1:1 Soil pH & Organic Matter \%LOI \\
\hline Jesi & & \\
\hline $\mathbf{1}$ & 8.4 & 1.7 \\
\hline $\mathbf{2}$ & 8.6 & 1.5 \\
\hline $\mathbf{3}$ & 8.5 & 1.8 \\
\hline $\mathbf{4}$ & 8.1 & 2 \\
\hline $\mathbf{5}$ & 8.2 & 2 \\
\hline Matelica & & \\
\hline $\mathbf{1}$ & 8.4 & 2.4 \\
\hline $\mathbf{2}$ & 8.3 & 3 \\
\hline $\mathbf{3}$ & 8.2 & 3.9 \\
\hline $\mathbf{4}$ & 8.3 & 4.2 \\
\hline $\mathbf{5}$ & 8.1 & 3.6 \\
\hline
\end{tabular}

Jesi and Matelica soil $\mathrm{pH}$ and organic matter content at individual soil profiles and at a soil depth of 10 $\mathrm{cm}$. Average Jesi had slightly more basic $\mathrm{pH}$ and less organic content than Matelica. 


\section{APPENDIX E:}

\section{Complete Soil Semi-Quantatative Mineralogy}

Relative mineral abundances for individual soil profiles at a soil depth of $10 \mathrm{~cm}$ was determined using XRD. Jesi is relatively abundant in dolomite $\left(\mathrm{CaMg}\left(\mathrm{CO}_{3}\right)_{2}\right)$ compared to Matelica, which showed no evidence of dolomite at $10 \mathrm{~cm}$ in depth. Jesi also has overall increased concentrations of calcite $\left(\mathrm{CaCO}_{3}\right)$ and albite $\left(\mathrm{NaAlSi}_{3} \mathrm{O}_{8}\right)$ compared to Matelica. They both have consistent high concentrations of quartz $\left(\mathrm{SiO}_{2}\right)$, as well as relative concentrations fairly distributed within the DOC's for minerals muscovite $\left(\mathrm{KAl}_{2}\left(\mathrm{AlSi}_{3} \mathrm{O}_{10}\right)(\mathrm{F}, \mathrm{OH})_{2}\right)$ and vermiculite $\left(\mathrm{Mg}, \mathrm{Fe}^{++}, \mathrm{Al}\right)_{3}(\mathrm{Al}, \mathrm{Si})_{4} \mathrm{O}_{10}(\mathrm{OH})_{2} \bullet 4\left(\mathrm{H}_{2} \mathrm{O}\right)$.

\begin{tabular}{cccccccccc}
\hline $\begin{array}{c}\text { Soil } \\
\text { Profile }\end{array}$ & Quartz & Calcite & Dolomite & Microcline & Albite & Muscovite & Kaolinite & Vermiculite & Montmorillonite \\
\hline Jesi & & & & & & & & & \\
\hline $\mathbf{1}$ & $\mathrm{XXX}$ & $\mathrm{XXX}$ & - & $\mathrm{XX}$ & $\mathrm{XX}$ & $\mathrm{X}$ & - & $\mathrm{X}$ & $\mathrm{X}$ \\
\hline $\mathbf{2}$ & $\mathrm{XXX}$ & $\mathrm{XXX}$ & $\mathrm{X}$ & $\mathrm{X}$ & $\mathrm{XX}$ & $\mathrm{XX}$ & $\mathrm{X}$ & $\mathrm{X}$ & $\mathrm{X}$ \\
\hline $\mathbf{3}$ & $\mathrm{XXX}$ & $\mathrm{XXX}$ & $\mathrm{X}$ & $\mathrm{XX}$ & $\mathrm{XX}$ & $\mathrm{X}$ & $\mathrm{X}$ & $\mathrm{X}$ & - \\
\hline $\mathbf{4}$ & $\mathrm{XXX}$ & $\mathrm{XXX}$ & $\mathrm{XX}$ & - & $\mathrm{XX}$ & $\mathrm{XX}$ & $\mathrm{X}$ & $\mathrm{X}$ & - \\
\hline $\mathbf{5}$ & $\mathrm{XXX}$ & $\mathrm{XXX}$ & $\mathrm{XX}$ & - & $\mathrm{XX}$ & $\mathrm{XX}$ & $\mathrm{X}$ & $\mathrm{X}$ & \\
\hline Matelica & & & & & & & & & \\
\hline $\mathbf{1}$ & $\mathrm{XXX}$ & $\mathrm{XXX}$ & - & $\mathrm{X}$ & $\mathrm{XX}$ & $\mathrm{XX}$ & $\mathrm{X}$ & $\mathrm{X}$ & $\mathrm{X}$ \\
\hline $\mathbf{2}$ & $\mathrm{XXX}$ & $\mathrm{XX}$ & - & $\mathrm{X}$ & $\mathrm{X}$ & $\mathrm{X}$ & $\mathrm{X}$ & $\mathrm{X}$ & $\mathrm{X}$ \\
\hline $\mathbf{3}$ & $\mathrm{XXX}$ & $\mathrm{XX}$ & - & $\mathrm{X}$ & $\mathrm{X}$ & $\mathrm{XX}$ & $\mathrm{X}$ & $\mathrm{X}$ & $\mathrm{X}$ \\
\hline $\mathbf{4}$ & $\mathrm{XXX}$ & $\mathrm{XXX}$ & - & $\mathrm{XX}$ & $\mathrm{X}$ & $\mathrm{X}$ & - & $\mathrm{X}$ & $\mathrm{X}$ \\
\hline $\mathbf{5}$ & $\mathrm{XXX}$ & - & - & $\mathrm{XX}$ & $\mathrm{X}$ & $\mathrm{X}$ & - & $\mathrm{X}$ & $\mathrm{X}$ \\
\hline
\end{tabular}




\section{APPENDIX F:}

\section{Total Jesi XRF Oxide Concentrations wt\%}

Total Jesi XRF oxide concentrations (wt\%) for individual soil profiles and soil depths (cm).

\begin{tabular}{lccccccccc}
\hline $\begin{array}{l}\text { Soil Profile and Soil Depth } \\
(\mathbf{c m})\end{array}$ & $\mathbf{S i O}$ & $\mathbf{A l}_{2} \mathbf{O}_{3}$ & $\mathbf{F e}_{2} \mathbf{O}_{3}$ & $\mathbf{T i O}_{2}$ & $\mathbf{M g O}$ & $\mathbf{C a O}$ & $\mathbf{N a} \mathbf{O}$ & $\mathbf{K}_{2} \mathbf{O}$ \\
\hline & Jesi & & & & & & & & \\
\hline $\mathbf{1 ( 3 )}$ & 57.80 & 10.20 & 3.46 & 0.39 & 1.14 & 11.40 & 1.11 & 2.43 \\
\hline $\mathbf{1 ( 1 0 )}$ & 58.20 & 10.30 & 3.46 & 0.39 & 1.17 & 11.60 & 1.13 & 2.43 \\
\hline $\mathbf{1 ( 2 5 )}$ & 57.10 & 10.50 & 3.60 & 0.41 & 1.25 & 12.10 & 1.08 & 2.34 \\
\hline $\mathbf{1 ( 5 0 )}$ & 50.00 & 10.10 & 3.78 & 0.41 & 1.46 & 15.90 & 0.86 & 2.05 \\
\hline $\mathbf{2 ( 3 )}$ & 41.30 & 9.29 & 3.75 & 0.42 & 1.95 & 21.30 & 0.70 & 1.86 \\
\hline $\mathbf{2 ( 1 0 )}$ & 41.00 & 9.22 & 3.82 & 0.41 & 1.93 & 21.50 & 0.71 & 1.84 \\
\hline $\mathbf{2 ( 2 5 )}$ & 41.00 & 10.10 & 3.90 & 0.46 & 2.16 & 20.70 & 0.59 & 1.97 \\
\hline $\mathbf{2 ( 5 0 )}$ & 42.70 & 10.40 & 4.25 & 0.45 & 2.11 & 19.40 & 0.72 & 1.98 \\
\hline $\mathbf{3 ( 3 )}$ & 46.00 & 10.50 & 4.11 & 0.47 & 1.80 & 17.30 & 0.70 & 2.00 \\
\hline $\mathbf{3 ( 1 0 )}$ & 45.40 & 10.60 & 4.12 & 0.47 & 1.82 & 17.90 & 0.69 & 1.96 \\
\hline $\mathbf{3 ( 2 5 )}$ & 47.50 & 10.80 & 4.19 & 0.49 & 1.77 & 16.70 & 0.74 & 1.97 \\
\hline $\mathbf{3 ( 5 0 )}$ & 47.70 & 10.80 & 4.17 & 0.49 & 1.77 & 16.50 & 0.75 & 1.96 \\
\hline $\mathbf{4 ( 3 )}$ & 38.50 & 9.90 & 4.15 & 0.47 & 4.30 & 19.20 & 0.50 & 2.09 \\
\hline $\mathbf{4 ( 1 0 )}$ & 38.50 & 9.97 & 4.15 & 0.47 & 4.27 & 18.80 & 0.51 & 2.06 \\
\hline $\mathbf{4 ( 2 5 )}$ & 42.00 & 7.97 & 3.27 & 0.41 & 5.18 & 18.20 & 0.69 & 1.70 \\
\hline $\mathbf{4 ( 5 0 )}$ & 37.90 & 9.78 & 4.13 & 0.46 & 4.47 & 19.00 & 0.50 & 2.03 \\
\hline $\mathbf{5 ( 3 )}$ & 46.50 & 12.00 & 4.58 & 0.56 & 3.02 & 12.30 & 1.00 & 2.43 \\
\hline $\mathbf{5 ( 1 0 )}$ & 48.80 & 12.60 & 4.93 & 0.59 & 3.12 & 11.50 & 0.99 & 2.34 \\
\hline $\mathbf{5 ( 2 5 )}$ & 55.20 & 14.40 & 5.53 & 0.69 & 2.49 & 6.53 & 1.18 & 2.60 \\
\hline $\mathbf{5 ( 5 0 )}$ & 49.10 & 13.00 & 5.06 & 0.60 & 2.82 & 11.30 & 1.08 & 2.42 \\
\hline & & & & & & & &
\end{tabular}




\section{APPENDIX G:}

\section{Total Jesi XRF Oxide and Elemental Concentrations ppm}

Total Jesi XRF oxide and elemental concentrations (ppm) for individual soil profiles and soil depths $(\mathrm{cm})$.

\begin{tabular}{|c|c|c|c|c|c|c|c|c|c|c|}
\hline Soil Profile and Soil Depth $(\mathbf{c m})$ & MnO & $\mathbf{Z n}$ & $\mathbf{N i}$ & $\mathrm{Sr}$ & Ba & $\mathbf{Z r}$ & V & $\mathrm{Cr}$ & Co & $\mathrm{Ce}$ \\
\hline \multicolumn{11}{|l|}{ Jesi } \\
\hline $1(3)$ & 825 & 38 & 43 & 261 & 429 & 111 & 70 & 107 & 10 & 47 \\
\hline $1(10)$ & 807 & 34 & 38 & 265 & 412 & 118 & 64 & 104 & 10 & 52 \\
\hline $1(25)$ & 820 & 37 & 46 & 273 & 449 & 116 & 71 & 72 & 12 & 47 \\
\hline $1(50)$ & 740 & 38 & 41 & 365 & 338 & 101 & 76 & 94 & ND & 50 \\
\hline $2(3)$ & 847 & 64 & 41 & 574 & 315 & 100 & 67 & 83 & 6 & 39 \\
\hline $2(10)$ & 863 & 45 & 46 & 576 & 348 & 98 & 79 & 77 & 8 & 43 \\
\hline $2(25)$ & 832 & 39 & 48 & 595 & 285 & 93 & 93 & 116 & 8 & 36 \\
\hline $2(50)$ & 974 & 51 & 51 & 567 & 283 & 110 & 87 & 112 & 12 & 40 \\
\hline $3(3)$ & 870 & 62 & 54 & 388 & 345 & 126 & 91 & 111 & 11 & 45 \\
\hline $3(10)$ & 865 & 66 & 56 & 407 & 323 & 110 & 81 & 133 & 9 & 50 \\
\hline $3(25)$ & 874 & 63 & 52 & 367 & 340 & 122 & 92 & 116 & 10 & 42 \\
\hline $3(50)$ & 957 & 76 & 57 & 362 & 383 & 125 & 70 & 109 & 11 & 43 \\
\hline $4(3)$ & 878 & 74 & 61 & 440 & 324 & 90 & 83 & 104 & 13 & 40 \\
\hline $4(10)$ & 846 & 77 & 63 & 437 & 301 & 84 & 78 & 133 & 10 & 37 \\
\hline $4(25)$ & 674 & 47 & 40 & 366 & 336 & 103 & 75 & 103 & 7 & 40 \\
\hline $4(50)$ & 813 & 74 & 49 & 422 & 298 & 92 & 89 & 113 & 10 & 42 \\
\hline $5(3)$ & 817 & 67 & 46 & 161 & 402 & 147 & 79 & 107 & 13 & 51 \\
\hline $5(10)$ & 723 & 57 & 68 & 151 & 461 & 160 & 90 & 110 & 14 & 55 \\
\hline $5(25)$ & 915 & 85 & 76 & 149 & 474 & 175 & 93 & 136 & 22 & 56 \\
\hline $5(50)$ & 851 & 82 & 67 & 171 & 457 & 153 & 85 & 114 & 21 & 47 \\
\hline
\end{tabular}




\section{APPENDIX H:}

\section{Total Matelica XRF Oxide Concentrations wt\%}

Total Matelica XRF oxide concentrations (wt\%) for individual soil profiles and soil depths $(\mathrm{cm})$.

\begin{tabular}{lccccccccc}
\hline $\begin{array}{c}\text { Soil Profile and Soil Depth } \\
(\mathbf{c m})\end{array}$ & $\mathrm{SiO}_{2}$ & $\mathrm{Al}_{2} \mathbf{O}_{3}$ & $\mathbf{F e}_{2} \mathbf{O}_{3}$ & $\mathbf{T i O}_{2}$ & $\mathbf{M g O}$ & $\mathbf{C a O}$ & $\mathbf{N a}_{2} \mathbf{O}$ & $\mathbf{K}_{2} \mathbf{O}$ \\
\hline & Matelica & & & & & & & & \\
\hline $\mathbf{1 ( 3 )}$ & 40.10 & 9.37 & 3.42 & 0.43 & 1.27 & 21.60 & 0.72 & 1.98 \\
\hline $\mathbf{1 ( 1 0 )}$ & 43.30 & 9.92 & 3.59 & 0.46 & 1.33 & 20.40 & 0.79 & 2.07 \\
\hline $\mathbf{1 ( 2 5 )}$ & 42.30 & 9.82 & 3.59 & 0.45 & 1.32 & 21.20 & 0.76 & 2.02 \\
\hline $\mathbf{1 ( 5 0 )}$ & 43.90 & 10.00 & 3.64 & 0.46 & 1.33 & 20.00 & 0.79 & 2.04 \\
\hline $\mathbf{2 ( 3 )}$ & 52.40 & 12.50 & 5.12 & 0.60 & 1.60 & 11.10 & 0.82 & 1.96 \\
\hline $\mathbf{2 ( 1 0 )}$ & 56.30 & 13.40 & 5.40 & 0.65 & 1.67 & 7.92 & 0.88 & 2.05 \\
\hline $\mathbf{2 ( 2 5 )}$ & 56.30 & 13.20 & 5.29 & 0.64 & 1.65 & 8.42 & 0.89 & 2.01 \\
\hline $\mathbf{2 ( 5 0 )}$ & 56.60 & 13.20 & 5.35 & 0.64 & 1.65 & 8.23 & 0.90 & 2.02 \\
\hline $\mathbf{3 ( 3 )}$ & 52.90 & 12.70 & 5.10 & 0.63 & 1.59 & 9.85 & 0.62 & 2.04 \\
\hline $\mathbf{3 ( 1 0 )}$ & 56.20 & 13.90 & 5.55 & 0.67 & 1.67 & 6.75 & 0.67 & 2.16 \\
\hline $\mathbf{3 ( 2 5 )}$ & 53.40 & 13.30 & 5.32 & 0.65 & 1.67 & 10.00 & 0.62 & 2.03 \\
\hline $\mathbf{3 ( 5 0 )}$ & 51.80 & 12.70 & 5.20 & 0.63 & 1.58 & 7.47 & 0.63 & 1.99 \\
\hline $\mathbf{4 ( 3 )}$ & 47.30 & 9.84 & 3.85 & 0.42 & 1.24 & 16.50 & 0.86 & 2.02 \\
\hline $\mathbf{4 ( 1 0 )}$ & 46.20 & 9.80 & 3.83 & 0.42 & 1.25 & 17.30 & 0.76 & 2.00 \\
\hline $\mathbf{4 ( 2 5 )}$ & 46.10 & 9.95 & 3.91 & 0.43 & 1.28 & 17.80 & 0.77 & 1.99 \\
\hline $\mathbf{4 ( 5 0 )}$ & 52.80 & 11.50 & 4.56 & 0.51 & 1.44 & 12.10 & 0.87 & 2.11 \\
\hline $\mathbf{5 ( 3 )}$ & 65.30 & 13.20 & 5.15 & 0.64 & 1.38 & 2.68 & 1.10 & 2.34 \\
\hline $\mathbf{5 ( 1 0 )}$ & 65.90 & 13.30 & 5.22 & 0.64 & 1.39 & 2.59 & 1.11 & 2.32 \\
\hline $\mathbf{5 ( 2 5 )}$ & 65.70 & 13.40 & 5.21 & 0.64 & 1.38 & 3.14 & 1.10 & 2.29 \\
\hline $\mathbf{5 ( 5 0 )}$ & 62.80 & 12.90 & 5.09 & 0.66 & 1.36 & 3.67 & 1.01 & 2.16 \\
\hline & & & & & & & &
\end{tabular}




\section{APPENDIX I:}

Total Matelica XRF Oxide and Elemental Concentrations ppm

Total Matelica XRF oxide and elemental concentrations (ppm) for individual soil profiles and soil depths $(\mathrm{cm})$.

\begin{tabular}{|c|c|c|c|c|c|c|c|c|c|c|}
\hline Soil Profile and Soil Depth $(\mathrm{cm})$ & MnO & $\mathbf{Z n}$ & $\mathrm{Ni}$ & $\mathrm{Sr}$ & Ba & $\mathbf{Z r}$ & V & $\mathrm{Cr}$ & Co & $\mathrm{Ce}$ \\
\hline \multicolumn{11}{|l|}{ Matelica } \\
\hline $1(3)$ & 908 & 69 & 47 & 468 & 329 & 114 & 78 & 77 & 8 & 40 \\
\hline $1(10)$ & 903 & 53 & 53 & 494 & 372 & 125 & 78 & 94 & 10 & 41 \\
\hline $1(25)$ & 957 & 55 & 43 & 503 & 323 & 131 & 75 & 88 & 8 & 45 \\
\hline $1(50)$ & 864 & 45 & 43 & 460 & 318 & 122 & 61 & 75 & 7 & 42 \\
\hline $2(3)$ & 1250 & 87 & 61 & 206 & 393 & 150 & 91 & 101 & 21 & 51 \\
\hline $2(10)$ & 1350 & 95 & 63 & 205 & 438 & 168 & 108 & 124 & 18 & 57 \\
\hline $2(25)$ & 1260 & 80 & 71 & 213 & 413 & 159 & 92 & 117 & 21 & 56 \\
\hline $2(50)$ & 1230 & 82 & 71 & 211 & 385 & 167 & 99 & 117 & 22 & 57 \\
\hline 3 (3) & 1640 & 76 & 61 & 135 & 464 & 142 & 112 & 127 & 17 & 54 \\
\hline $3(10)$ & 1770 & 96 & 84 & 142 & 488 & 167 & 107 & 127 & 26 & 62 \\
\hline $3(25)$ & 1610 & 88 & 72 & 162 & 515 & 147 & 112 & 109 & 22 & 60 \\
\hline $3(50)$ & 1660 & 85 & 66 & 124 & 472 & 149 & 97 & 114 & 21 & 58 \\
\hline $4(3)$ & 1220 & 63 & 46 & 319 & 347 & 114 & 64 & 108 & 12 & 45 \\
\hline $4(10)$ & 1270 & 74 & 51 & 317 & 349 & 105 & 86 & 86 & 13 & 45 \\
\hline $4(25)$ & 1190 & 66 & 38 & 332 & 325 & 108 & 66 & 97 & 7 & 47 \\
\hline $4(50)$ & 1310 & 57 & 56 & 253 & 345 & 130 & 87 & 109 & 14 & 50 \\
\hline $5(3)$ & 1490 & 93 & 68 & 139 & 429 & 174 & 89 & 116 & 28 & 63 \\
\hline $5(10)$ & 1820 & 81 & 61 & 154 & 423 & 173 & 97 & 140 & 26 & 55 \\
\hline $5(25)$ & 1440 & 70 & 62 & 162 & 444 & 193 & 90 & 135 & 19 & 54 \\
\hline $5(50)$ & 1490 & 66 & 59 & 163 & 422 & 172 & 108 & 127 & 20 & 55 \\
\hline
\end{tabular}




\section{APPENDIX J:}

\section{Mean Jesi and Matelica XRF Elemental and Oxide Concentrations}

Mean elemental and oxide concentrations for DOCs in units ppm and wt\% at a soil depth of $10 \mathrm{~cm}$. Statistical variations ( $p$-value) are also listed (1way ANOVA).

\begin{tabular}{|c|c|c|c|}
\hline $\begin{array}{c}\text { Elemental \& } \\
\text { Oxide } \\
\text { Concentrations }\end{array}$ & $\begin{array}{c}\text { Jesi } \\
\text { Mean }(S D)\end{array}$ & $\begin{array}{c}\text { Matelica } \\
\text { Mean }(S D)\end{array}$ & $p$-value \\
\hline $\mathrm{MnO}$ ppm & $\begin{array}{l}820.8 \\
(59.4) \\
\end{array}$ & $\begin{array}{l}1422.6 \\
(379.9) \\
\end{array}$ & * 0.008 \\
\hline Co ppm & $\begin{array}{l}10.2 \\
(2.3)\end{array}$ & $\begin{array}{c}18.6 \\
(7.3)\end{array}$ & * 0.031 \\
\hline V ppm & $\begin{array}{l}78.4 \\
(9.3) \\
\end{array}$ & $\begin{array}{c}95.2 \\
(13.1)\end{array}$ & * 0.048 \\
\hline $\mathrm{Zn} \mathrm{ppm}$ & $\begin{array}{c}55.8 \\
(16.9)\end{array}$ & $\begin{array}{c}79.8 \\
(17.7)\end{array}$ & 0.060 \\
\hline Ni ppm & $\begin{array}{c}54.2 \\
(12.3) \\
\end{array}$ & $\begin{array}{c}62.4 \\
(13.1) \\
\end{array}$ & 0.337 \\
\hline Sr ppm & $\begin{array}{c}367.2 \\
(163.7)\end{array}$ & $\begin{array}{c}262.4 \\
(146.8)\end{array}$ & 0.318 \\
\hline Ba ppm & $\begin{array}{c}369 \\
(66.1) \\
\end{array}$ & $\begin{array}{c}414 \\
(55.1)\end{array}$ & 0.276 \\
\hline $\mathrm{Zr}$ ppm & $\begin{array}{l}114.0 \\
(28.7) \\
\end{array}$ & $\begin{array}{l}147.6 \\
(30.7) \\
\end{array}$ & 0.112 \\
\hline Cr ppm & $\begin{array}{l}111.4 \\
(23.3)\end{array}$ & $\begin{array}{l}114.2 \\
(23.1)\end{array}$ & 0.853 \\
\hline Ce ppm & $\begin{array}{l}47.4 \\
(7.3) \\
\end{array}$ & $\begin{array}{l}52.0 \\
(8.7) \\
\end{array}$ & 0.392 \\
\hline $\mathrm{SiO}_{2} \% \mathrm{wt} \%$ & $\begin{array}{c}46.4 \\
(0.077)\end{array}$ & $\begin{array}{c}53.6 \\
(0.090) \\
\end{array}$ & 0.212 \\
\hline $\mathrm{Al}_{2} \mathrm{O}_{3} \%$ wt $\%$ & $\begin{array}{c}10.5 \\
(0.013) \\
\end{array}$ & $\begin{array}{c}12.1 \\
(0.0093) \\
\end{array}$ & 0.191 \\
\hline $\mathrm{Fe}_{2} \mathrm{O}_{3} \% \mathrm{wt} \%$ & $\begin{array}{c}4.10 \\
(0.0054) \\
\end{array}$ & $\begin{array}{c}4.72 \\
(0.0093) \\
\end{array}$ & 0.233 \\
\hline $\mathrm{MgO} \% \mathrm{wt} \%$ & $\begin{array}{c}2.46 \\
(0.012) \\
\end{array}$ & $\begin{array}{c}1.46 \\
(0.0020)\end{array}$ & 0.111 \\
\hline $\mathrm{CaO} \% \mathrm{wt} \%$ & $\begin{array}{c}16.3 \\
(0.045) \\
\end{array}$ & $\begin{array}{c}11.0 \\
(0.075) \\
\end{array}$ & 0.216 \\
\hline $\mathrm{Na}_{2} \mathrm{O} \%$ wt $\%$ & $\begin{array}{c}0.805 \\
(0.0025)\end{array}$ & $\begin{array}{c}0.842 \\
(0.0017)\end{array}$ & 0.794 \\
\hline $\mathrm{K}_{2} \mathrm{O} \%$ wt $\%$ & $\begin{array}{c}2.13 \\
(0.0025) \\
\end{array}$ & $\begin{array}{c}2.12 \\
(0.0013) \\
\end{array}$ & 0.963 \\
\hline $\mathrm{TiO}_{2} \% \mathrm{wt} \%$ & $\begin{array}{c}0.464 \\
(0.00080)\end{array}$ & $\begin{array}{c}0.568 \\
(0.0012)\end{array}$ & 0.143 \\
\hline
\end{tabular}




\section{APPENDIX K:}

\section{Jesi and Matelica Base Saturation and CEC}

Jesi and Matelica base saturation and CEC values at individual soil profiles at a soil depth of $10 \mathrm{~cm}$.

\begin{tabular}{cccccc}
\hline Soil Profile & \%Mg & \% K & \% Ca & \% Na & CEC (\%) \\
\hline Jesi & & & & & \\
\hline $\mathbf{1}$ & 5 & 5 & 89 & 1 & 33.1 \\
\hline $\mathbf{2}$ & 14 & 6 & 79 & 1 & 35.7 \\
\hline $\mathbf{3}$ & 7 & 4 & 88 & 1 & 37.4 \\
\hline $\mathbf{4}$ & 11 & 4 & 84 & 1 & 34.5 \\
\hline $\mathbf{5}$ & 7 & 2 & 90 & 1 & 34.4 \\
\hline Matelica & & & & & \\
\hline $\mathbf{1}$ & 3 & 5 & 91 & 1 & 36.5 \\
\hline $\mathbf{2}$ & 5 & 3 & 91 & 1 & 47.3 \\
\hline $\mathbf{3}$ & 4 & 4 & 91 & 0 & 48.1 \\
\hline $\mathbf{4}$ & 4 & 5 & 90 & 0 & 35.7 \\
\hline $\mathbf{5}$ & 5 & 5 & 89 & 1 & 38.4 \\
\hline
\end{tabular}




\section{APPENDIX L:}

Jesi Soil Elemental Concentrations N, C, and P wt\%

Jesi N, C, and P concentrations (wt $\%$ ) for individual soil profiles and soil depths $(\mathrm{cm})$.

\begin{tabular}{|c|c|c|c|}
\hline Soil Profile and Soil Depth $(\mathrm{cm})$ & $\mathbf{N}$ & $\mathbf{C}$ & $\mathbf{P}$ \\
\hline \multicolumn{4}{|l|}{ Jesi } \\
\hline $1(3)$ & 0.120 & 0.957 & 0.0918 \\
\hline $1(10)$ & 0.086 & 0.633 & 0.0855 \\
\hline $1(25)$ & 0.081 & 0.592 & 0.0872 \\
\hline $1(50)$ & 0.067 & 0.407 & 0.0800 \\
\hline $2(3)$ & 0.088 & 0.816 & 0.0997 \\
\hline $2(10)$ & 0.096 & 0.816 & 0.1167 \\
\hline $2(25)$ & 0.063 & 0.457 & 0.1078 \\
\hline $2(50)$ & 0.052 & 0.252 & 0.1036 \\
\hline $3(3)$ & 0.130 & 1.115 & 0.1111 \\
\hline $3(10)$ & 0.106 & 0.762 & 0.1103 \\
\hline $3(25)$ & 0.116 & 0.842 & 0.1013 \\
\hline $3(50)$ & 0.109 & 0.780 & 0.0974 \\
\hline $4(3)$ & 0.160 & 2.498 & 0.1189 \\
\hline $4(10)$ & 0.126 & 1.970 & 0.1201 \\
\hline $4(25)$ & 0.047 & 2.353 & 0.0959 \\
\hline $4(50)$ & 0.114 & 1.888 & 0.1080 \\
\hline $5(3)$ & 0.195 & 2.652 & 0.1208 \\
\hline $5(10)$ & 0.099 & 1.452 & 0.0854 \\
\hline $5(25)$ & 0.089 & 0.924 & 0.0797 \\
\hline $5(50)$ & 0.096 & 1.076 & 0.0857 \\
\hline
\end{tabular}




\section{APPENDIX M:}

Matelica Soil Elemental Concentrations N, C, and P wt \%

Matelica N, C, and P concentrations (wt \%) for individual soil profiles and soil depths $(\mathrm{cm})$.

\begin{tabular}{|c|c|c|c|}
\hline Soil Profile and Soil Depth $(\mathrm{cm})$ & $\mathbf{N}$ & C & $\mathbf{P}$ \\
\hline \multicolumn{4}{|l|}{ Matelica } \\
\hline $1(3)$ & 0.174 & 1.537 & 0.1373 \\
\hline $1(10)$ & 0.161 & 1.366 & 0.1285 \\
\hline $1(25)$ & 0.171 & 1.495 & 0.1339 \\
\hline $1(50)$ & 0.173 & 1.504 & 0.1255 \\
\hline $2(3)$ & 0.141 & 1.363 & 0.0907 \\
\hline $2(10)$ & 0.117 & 1.019 & 0.0864 \\
\hline $2(25)$ & 0.107 & 0.912 & 0.0820 \\
\hline $2(50)$ & 0.103 & 0.850 & 0.0843 \\
\hline $3(3)$ & 0.174 & 1.782 & 0.1260 \\
\hline $3(10)$ & 0.170 & 1.654 & 0.1191 \\
\hline $3(25)$ & 0.152 & 1.499 & 0.1077 \\
\hline $3(50)$ & 0.188 & 1.880 & 0.1182 \\
\hline $4(3)$ & 0.251 & 2.713 & 0.1338 \\
\hline $4(10)$ & 0.230 & 3.283 & 0.1289 \\
\hline $4(25)$ & 0.168 & 1.840 & 0.1272 \\
\hline $4(50)$ & 0.134 & 1.264 & 0.1149 \\
\hline $5(3)$ & 0.176 & 1.850 & 0.1200 \\
\hline $5(10)$ & 0.171 & 1.628 & 0.1248 \\
\hline $5(25)$ & 0.128 & 1.123 & 0.0939 \\
\hline $5(50)$ & 0.099 & 0.867 & 0.0885 \\
\hline
\end{tabular}




\section{APPENDIX N:}

\section{Soil Plant Available Nutrients wt $\%$}

Jesi and Matelica plant available $\mathrm{NO}_{3}{ }^{-}$and $\mathrm{P}$ values (wt\%) at individual soil profiles at a soil depth of $10 \mathrm{~cm}$.

\begin{tabular}{lcc}
\hline Soil Profile & $\mathbf{N O}_{3}{ }^{-}$ & $\mathbf{P}$ \\
\hline Jesi & & \\
\hline 1 & 0.00230 & 0.0120 \\
\hline 2 & 0.00200 & 0.0123 \\
\hline 3 & 0.00120 & 0.0074 \\
\hline 4 & 0.00250 & 0.0216 \\
\hline 5 & 0.00420 & 0.0075 \\
\hline Matelica & & \\
\hline 1 & 0.00420 & 0.0433 \\
\hline 2 & 0.00100 & 0.0085 \\
\hline 3 & 0.00460 & 0.0146 \\
\hline 4 & 0.01580 & 0.0383 \\
\hline 5 & 0.00120 & 0.0235 \\
\hline
\end{tabular}




\section{APPENDIX O:}

\section{Grapevine Stem Elemental Concentrations N, C, and P wt\%}

\begin{tabular}{|c|c|c|c|}
\hline Soil Profile & $\mathbf{N}$ & $\mathrm{C}$ & $\mathbf{P}$ \\
\hline \multicolumn{4}{|l|}{ Jesi } \\
\hline 1 & 0.403 & 42.681 & 0.193 \\
\hline 2 & 0.400 & 45.519 & 0.258 \\
\hline 3 & 0.418 & 44.446 & 0.298 \\
\hline 4 & 0.412 & 44.868 & 0.272 \\
\hline 5 & 0.493 & 45.090 & 0.200 \\
\hline \multicolumn{4}{|l|}{ Matelica } \\
\hline 1 & 0.556 & 44.879 & 0.202 \\
\hline 2 & 0.385 & 45.393 & 0.173 \\
\hline 3 & 0.485 & 45.131 & 0.139 \\
\hline 4 & 0.599 & 45.659 & 0.131 \\
\hline 5 & 0.444 & 45.637 & 0.196 \\
\hline
\end{tabular}

